\title{
A Review on Phase Change Materials for Thermal Energy Storage in Buildings: Heating and Hybrid Applications
}

\author{
Khaireldin Faraj ${ }^{1}$, Mahmoud Khaled ${ }^{2,3^{*}}$, Jalal Faraj ${ }^{2,4}$, Farouk Hachem ${ }^{1}$, Cathy Castelain ${ }^{5}$ \\ ${ }^{1}$ Energy and Thermo-Fluid Group, Lebanese International University, LIU, PO Box 146404 Beirut, Lebanon. \\ ${ }^{2}$ Energy and Thermo-Fluid Group, The International University of Beirut BIU, PO Box 146404 Beirut, Lebanon. \\ ${ }^{3}$ University Paris Diderot, Sorbonne Paris Cite, Interdisciplinary Energy Research Institute (PIERI), Paris, France. \\ ${ }^{4}$ Lebanese university, Faculty of Technology, Saida, Lebanon \\ ${ }^{5}$ Laboratory of Thermal Energy of Nantes, LTEN, Polytech' Nantes, University of Nantes, Nantes-France.
}

*In correspondence to: Mahmoud Khaled, International University of Beirut, PO Box 146404, Beirut, Lebanon E-mail : mahmoud.khaled@liu.edu.lb; Phone : 009611706881/2/3/4 ; Fax : 009611306044

\begin{abstract}
Researchers world-wide are investigating thermal energy storage, especially phase change materials, for their substantial benefits in improving energy efficiency, sustaining thermal comfort in buildings and contributing to the reduction of environmental pollution. Residential buildings and commercial constructions, being dependent on heating and cooling systems, are subjected to the utilization of PCM technology through several applications. The current study presents a state-of-the-art review that covers recent literature on thermal energy storage systems utilizing PCMs for buildings. The reviewed applications are heating and hybrid applications, that are categorized as passive and active systems. A summary of the PCMs used, applications, thermo-physical properties and incorporation methods are presented as well. The study emphasizes the promising effectiveness of PCM in building heating applications, and highlights the significance of PCM system hybridization. The study shows that experimental investigations on commercial constructions, and hybrid systems development and optimization, are still required. Finally, possible combinations of active and passive heating applications with their auspicious benefits in terms of energy efficiency augmentation, are recommended.
\end{abstract}

\section{Highlights}

- $\quad$ State-of-the-art review on PCM building applications for heating and hybrid systems

- Active and Passive classification for heating and hybrid systems

- Challenges altering the PCM technology for energy-efficient buildings are addressed

- Hybridization of active and passive systems forms a potential method toward NZEB

Keywords: PCM, latent heat, heating, hybrid, thermal energy storage, building.

\section{Introduction}

Recent and current developing research has been focused on increasing energy efficiency by the share of renewable energy, energy demand management and reduction for both heating and cooling. This has originated from the remarkable increase of energy demand all over the world as a result of world population and economy rapid growth, which in turns, is leading to severe environmental impact [1-8]. According toKaya and Yokoburi[9], the total carbon emissions that leads to global warming is influenced by economic growth, the intensity of energy consumption, population growth and intensity of carbon emissions. However, researchers and policymakers have attributed carbon emission's high-intensity to energy consumption resulting from rapid economic growth and the amplified usage of fossil fuels [10-12]. Taking the United States (U.S.) as an example, more than $90 \%$ of greenhouse gas emissions including $\mathrm{CO}_{2}$, that causes the change in climate, are caused by the combustion of fossil fuels [13]. According to the International Energy Agency (IEA), the respective increase in the primary energy production and $\mathrm{CO}_{2}$ emissions has reached $49 \%$ and $43 \%$ respectively, over the past 20 years 
[14]. The building sector, being the largest energy-consuming sector, accounts for about 25-30\% of final energy consumption on global basis [15,16], and

\begin{tabular}{|llll|}
\hline Abbreviations & & & \\
PCM & Phase Change Material & SSPCM & Shape stabilized phase change material \\
TES & Thermal Energy Storage & TCM & Thermochemical material \\
LHTES & Latent Heat Thermal Energy Storage & TW & Trombe wall \\
NZEB & Net Zero Energy Building & CHP & Combined heat and power \\
ZEB & Zero energy building & HVAC & Heating, ventilating and air conditioning \\
PE & Polyethylene & CAP & Capillary coils \\
SAH & Solar air heater & DSC & Differential scanning calorimetry \\
SWH & Solar water heater & FT-IR & Fourier transformer infrared spectroscopy \\
TGA & Thermo-gravimetric analysis & SEM & Scanning electron microscopy \\
CFD & Computational fluid dynamics & HDPE & High density polyethylene \\
EG & Expanded graphite & & \\
& & & \\
Units & & Conductivity & W/m.K \\
Temperature & ${ }^{\circ} \mathrm{C}$ & Specific Heat & $\mathrm{kJ} / \mathrm{kg} . \mathrm{K}$ \\
Enthalpy & $k J / k g$ & & \\
& &
\end{tabular}

is considered an equally important source of $\mathrm{CO}_{2}$ emission [17]. Besides, according to IEA, if no energy efficiency improvements are carried out in the building sector, an increase of $50 \%$ in energy consumption might be triggered by 2050 [18]. Globally, the building sector is the main source for energy consumption that accounts for about $40 \%$ of the total energy usage [19-22]. IEA Solar Heating and Cooling Program findings emphasized that over $75 \%$ of consumed energy in single and multifamily houses are attributed to the space heating and cooling demand [23]. However, the environmental crisis is at the beginning, where the expectations show that the energy demand in the building sector will be have risen by $50 \%$ by 2050 , with the space cooling demand being tripled at the forecasted period [24].

Therefore, researchers seek potential solutions to ameliorate energy conservation and energy storage as an attempt to decrease global energy consumption [25], and demolishing the crisis of global warming. For instance, a policy known as 20-20-20 was established by the EU where the three numbers correspond to: $20 \%$ reduction in $\mathrm{CO}_{2}$ emissions, $20 \%$ increase in energy efficiency, and $20 \%$ increase in renewable energy share by 2020 [23,2628]. An extensive technique, regarding cooling and heating improvement by reducing the energy demand in building sector, is the application of phase change materials known as "PCM". PCM has received much attention and has become a topic with a lot of interest among architects and engineers in the last four decades [29]. PCMs work as latent heat thermal energy storage strategies that absorb the excess energy in buildings filling the gap between energy supply and demand, controlling internal temperature, thus enhancing thermal comfort, which makes it a promising technology [30,31]. Currently, the use of phase change materials (PCMs) have been widely developed in different fields and applications, where commercial PCMs cover a wide temperature range from $30^{\circ} \mathrm{C}$ to $850^{\circ} \mathrm{C}$ [32]. The wide range is covered by different incorporation techniques: Macro-encapsulation, micro-encapsulation, direct mixing, immersion, and shape-stabilization [33]. At this point, micro-encapsulation introduces the use of PCM slurries in a variety of applications at specified temperature ranges. Plenty of researchers investigated the performance of PCM slurries in their studies [34-40].

Abundant review articles have been published in the field of energy storage, including: general studies on Energy storage types and applications [41], generalized reviews covering the use of PCM in several applications covering all ranges of temperatures [30], specified reviews covering the use of PCM in building applications only $[24,42,43]$, critical articles covering experimental researches on the usage of PCM in buildings [44], and critical articles related to: PCM transition studies with specific encapsulation (Spherical Capsules for example [45]) and used storage containers [46]. A summary of some recent review articles in the domain of PCM-TES is presented in section 1.1 below. It shows the importance of the subject and its immensity.

\subsection{Summary of recent review articles on PCM applications in buildings}


Applications of PCM have covered a wide range of energy-dependent entities and resources. Such applications are: solar energy (such as solar dryers [47] and solar domestic hot water systems [48]), industrial heat recovery, industrial worker equipment (such as helmets [49]), electrical power peaking regulation, textiles, healthcare, liquefied natural gas, green house agriculture, buildings and aerospace [50]. The use of PCM in buildings for heating and cooling applications as TES systems has been widely reviewed by researchers all over the world [30,44,50-61]. Tyagi et al. published a state of the art review paper on PCM thermal storage in buildings [55], where various possible PCM based technological methods for heating and cooling in building sector were deliberated. Solar passive building concepts, PCMs for space heating and cooling and their applications in passive and active systems are discussed. Active PCM-TES systems including: floor heating, ceiling boards and other systems, and Passive PCM-TES systems including: PCM Trombe wall, PCM wall board, PCM shutters, PCM building blocks, Air-based heating systems, floor heating and ceiling boards described by the authors proved to have good potential for reducing the heating and cooling loads in buildings. A massive recent review paper conducted by Du et al. [30] who reviewed the applications of PCMs in cooling, heating and energy generation in four temperature ranges shown in Table 1 and concluded that: For low temperature range $\left(-20^{\circ} \mathrm{C}\right.$ to $\left.5^{\circ} \mathrm{C}\right)$ : PCMs used are mainly organic compounds. For medium-low temperature range $\left(5^{\circ} \mathrm{C}\right.$ to $\left.40^{\circ} \mathrm{C}\right)$ : PCMs used are mainly organic compounds and salt hydrates. For medium temperature range $\left(40^{\circ} \mathrm{C}\right.$ to $\left.80^{\circ} \mathrm{C}\right)$ : Organic PCMs like paraffin and fatty acids are mainly used, where for electric devices the contribution of PCM as a TES cooling system increased its operational efficiency and life span by up to $26 \%$ and $300 \%$, respectively. And finally, for high temperature range $\left(80^{\circ} \mathrm{C}\right.$ to $\left.200^{\circ} \mathrm{C}\right)$ : Few organic PCMs are used with their acceptable performance improvement, while molten salt still dominates the TES sector for a long time with its lifespan and economic benefits. A critical review on the experimental studies regarding the applications of PCMs and nano-enhanced PCMs in buildings was done by Kasaeian et al. [44]. The study covered literature on passive and active methods for integrating PCMs for cooling, heating, hybrid, and air-conditioning applications as well as the use of nano-enhanced PCMs in buildings, where the main conclusions drawn by the authors reveal that the use of PCM in buildings in its different application form lead to decrease in energy consumption, shift the heating and cooling load, decrease fluctuations of temperature and alleviate thermal indoor temperature thus enhancing the thermal comfort. The authors mentioned gaps in literature articles that are summarized as: (1) Optimization including economy is lacking; (2) Computational fluid dynamics (CFD) analysis, exergy analysis and exergo-economic analysis; (3) Studies on developing suitable simulating tools to predict the behavior of buildings with high construction funds; (4) Combination of PCMs in solar buildings and zero energy buildings (ZEB) need to be investigated; and (5) regional studies are needed.

Lin et al. [56] reviewed the techniques followed by researchers for enhancing the thermal conductivity of PCMs. The study covered the two enhancement methods of adding highly thermal conductive additives and encapsulation of PCMs. After comparing different techniques and analyzing their effect especially the magnification impact on the conductivity of PCM, it was concluded that adding high thermal conductivity materials to PCMs is more efficient with carbon-based additives being the most promising in terms of application prospect for having better stability, density and favorable thermal conductivity compared to other fillers. Itenet et al. [57] demonstrated a thorough review on the air-PCM-TES applications for free cooling and heating of buildings. The study summarized active and passive free heating and cooling applications and confirmed that despite the advantage of having low initial and running cost, passive methods in buildings face limitations in heat storage rates in climates with low temperature difference, a problem that is solved by adapting active methods for heat transfer enhancement. A massive review by Pandey et al. [58] summarized the recent advances in using PCM in solar energy systems to bridge the gap between discontinuous solar energy supply and energy demand. The study also covered the application of PCM solar systems in buildings for heating and cooling purposes. It was traced that the incorporation of PCM in Photovoltaics as well as in solar thermal systems guarantee a sustainable solution for these systems.

Huang et al. [50] reviewed methods of improving thermal conductivities and heat transfer rates for composite PCMs used in latent heat thermal energy storage systems and thermal management systems, after classifying them in three Morphological categories: Fiber, Porosity and Sphere. It was shown that nano-fibers and carbon fibers have promising thermal properties. Microencapsulated PCM having spherical shapes gained the attention world 
widely with the willing to improve their thermal properties. The authors also presented several methods for the fabrication of enhanced thermal properties. However, the authors did not include all building applications for it was not the main objective as morphological characterizations. Zeng et al. [61] studied the adaptability of PCMbased technologies in their country China. It was shown that despite the promising influence on Chinese residential buildings, more studies can be conducted analyzing the effect of continuous climate change instead of seasonal analysis covering extreme cold and extreme hot weather conditions only (i.e. winter and summer). A review on the current status of PCM research investigating areas that had less attention in the engineering and science community like toxicity, health hazard, and commercialization was conducted by Chandel et al. [51]. The study showed the advantage of salt hydrates over paraffin in terms of safety and health threats, where the former proved to be safe if handled carefully while the latter being flammable releases toxic vapor. However, literature on fire retardation with respect to PCM is still lacking, as well as the real utilization of new innovative PCMs. House design integrated with energy saving system available in the United Kingdom (UK), in particular solar energy, heat pumps, phase changing materials (PCMs) and micro combined heat and power (micro-CHP) systems was the aim set by Xie et al. [52] in their review. It was shown that a saving of $19.5 \%$ could be achieved in the designed system incorporating PCM. Lin et al. [62] reviewed the applications and thermal performances of TES systems for the case of using inorganic PCMs. Other review articles were revealed by Navarro et al. in their reviews published since $2016[63,64]$ related to active and passive thermal energy storage systems integrated in buildings. Alva et al. [65] who prepared an overview on thermal energy storage systems, where the study reviewed different TES types: Sensible, latent and chemical storage systems; Guo et al. [66] who reviewed the utilization of hybrid renewable energy systems, Gracia et al. [59] who analyzed the lessons learnt from experiments on active and passive systems with PCM in Spain, Hicham Johra and Heiselberg [53] who reviewed the integration of PCM in furniture and the influence of internal thermal mass on indoor thermal dynamics, Giro-Paloma et al [54] who reviewed all about microencapsulated PCMs, and much more literature reviews that show this tremendous interest in PCM and their applications, particularly buildings where special focus was given to cooling potential of PCM [67-73].

After taking variety of massive published review articles into consideration, it is proved that the domain of latent heat thermal energy storage using PCM is of valuable importance. Summarized review articles are either generalized for several applications of PCM, or narrowed within a specified application. The purpose of the current review article is to present a thorough review on the use of PCM as LHTES in buildings for heating and hybrid (mixing of heating and cooling) applications to give relative recommendations for future researches. The study summarizes the basics of PCM technology through a comprehensive section. Heating and hybrid applications are summarized through a hirechary diagram and studies specifications with used PCMs are tabulated. Finally, Possible combined systems that are lacking are recommended through an illustrative table.

Table 1 Classification of reviewed applications of PCMs in the four temperature ranges [30]

\begin{tabular}{|c|c|c|c|}
\hline \multicolumn{2}{|c|}{ Temperature range $\left({ }^{\circ} \mathrm{C}\right)$} & Mode & Application \\
\hline \multirow{11}{*}{$\begin{array}{c}\text { Specific temperature } \\
\text { ranges of reviewed PCM } \\
\text { applications } \\
\left(-20^{\circ} \mathrm{C} \text { to } 200^{\circ} \mathrm{C}\right)\end{array}$} & \multirow{2}{*}{$\begin{array}{c}\text { Low } \\
\left(-20^{\circ} \mathrm{C} \text { to } 5^{\circ} \mathrm{C}\right)\end{array}$} & \multirow{2}{*}{ Cooling } & Domestic refrigerator \\
\hline & & & Commercial refrigerated products \\
\hline & \multirow{5}{*}{$\begin{array}{l}\text { Medium-Low } \\
\left(5^{\circ} \mathrm{C} \text { to } 40^{\circ} \mathrm{C}\right)\end{array}$} & Heating + Cooling & Building passive heating and cooling \\
\hline & & \multirow{4}{*}{ Cooling } & Free cooling \\
\hline & & & Solar absorption chiller \\
\hline & & & Evaporative and radiative cooling \\
\hline & & & Air conditioning system \\
\hline & \multirow{4}{*}{$\begin{array}{c}\text { Medium } \\
\left(40^{\circ} \mathrm{C} \text { to } 80^{\circ} \mathrm{C}\right)\end{array}$} & Cooling & Electric device \\
\hline & & \multirow{3}{*}{ Heating } & Solar air heater \\
\hline & & & Solar stills \\
\hline & & & Solar domestic hot water \\
\hline
\end{tabular}




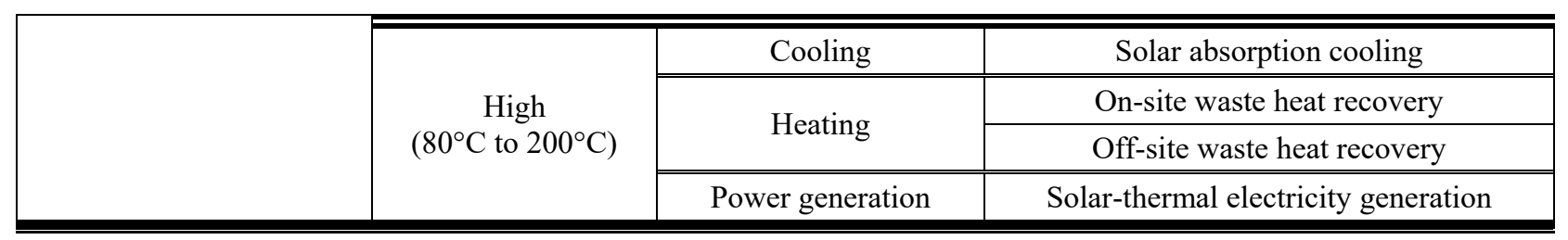

\subsection{Scope of the review article}

The methodology followed in creating this paper work is subjected to some limitations to bound the challenging review of the massive science related to phase change material technology. Firstly, the priority is given to published articles since the year 2015 in order to keep the review up-to-date. Secondly, the paper reviews literature on both basis: numerical and experimental, for the two applications in buildings: heating and hybrid applications (mixing of heating and cooling).

The review is divided into five sections rather than the introduction. It starts in section 2 about thermal energy storage and phase change material as a promising technology within latent thermal energy storage systems. The chapter is subdivided into four sections covering a general background of PCM including its history and functioning modes, material classification, PCM selection criteria and the corresponding measurement methods, which makes the paper comprehensive regarding the base of the studied domain. Then, section 3 deals with the use of PCM-TES for heating applications in buildings, chapter 4 deals with the use of PCM-TES for hybrid applications (i.e. combined heating and cooling) in buildings. Chapters 3 and 4 each covers two sub-sections for active and passive methods. Then, chapter 5 discusses the major outcomes in the literature. At this level discussions regarding the adaptation methods scarcity and insufficiency, and possible extensions of PCM technology integration in buildings are performed. Finally, chapter 6 highlights vital recommendations after drawing detailed conclusions.

\section{Thermal Energy Storage (TES)}

Climatic conditions were considered in the manufacturing process of traditional buildings long time ago where the usage of materials with high thermal mass became the conventional method for keeping indoor cool in summer and warm in winter [55]. However, due to the increase in population and the improvement in architectural engineering with high-rise construction designs to which man is best adapted, building materials are substituted with lightweight materials that lack high thermal mass and heat capacitance property. This led to the installation of mechanical equipment for heating and cooling demand involving large amount of energy expense. For that, the use of thermal energy storage (TES) systems which are combined with building was triggered as an efficient and promising technology that aims for reducing energy demand, shifting cooling/heating loads in time (peak shaving), and improving heating/cooling systems by increasing the thermal efficiency or reducing harmful greenhouse gases emissions [42]. TES is the key toward providing "Energy Flexibility" in buildings [74]. Sharma et al [75] included in their study that different types of thermal storage of solar energy are divided into two categories: (1) Thermal and (2) Thermochemical (see Figure 1 below). Fundamentally, TES is subdivided into three categories: Sensible heat storage, Latent heat storage, and Thermochemical heat storage (TCM-TES) $[23,76]$. Nevertheless, due to the lack of commercially available TCM-TES systems, and due to high material costs and unknown lifespan [42], the main categories for TES techniques are: sensible heat storage and latent heat storage $[13,29]$. Deciding which storage technique to use, it is important to detect the ratio between the building's envelope size, used materials and their volume with their respective thermal mass which represent the most significant factors influencing the thermal response [29]. In their study, Morrison and Abdulkhalik [77] showed that for air-based system, the storage volume of a rock-bed unit (which is a sensible TES method) is 4 times greater than that in a system utilizing Sodium Sulfate Decahydrate $\left(\mathrm{Na}_{2} \mathrm{SO}_{4} \cdot 10 \mathrm{H}_{2} \mathrm{O}\right)$ and double that in a system utilizing paraffin wax (which are latent TES methods). The proven higher heat storage capacity over a constant temperature behavior during phase transition reflect the progressive efficiency that latent heat energy storage 
materials have over sensible storage materials $[78,79]$. Another study by Ghoneim [80] proved that the required storage volume of a conventional water tank (which is a sensible TES method) is roughly double that of sodium sulfate (which is a latent TES method) to realize the same system performance. Consequently, lightweight construction incorporated with PCM-LHTES, having high storage density, is more efficient, especially with their capability of storing energy between 5 and 14 times more heat per unit volume than sensible heat storage materials like water, masonry and rock [17].

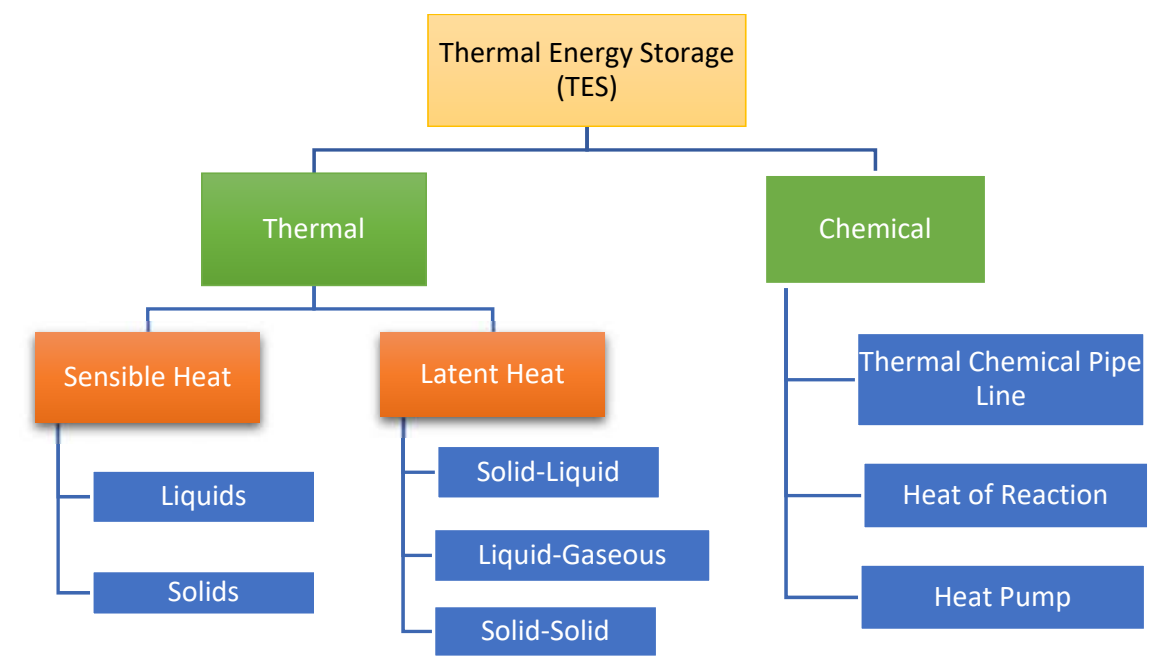

Figure 1 Different types of thermal energy storage for solar energy [75].

\subsection{Phase Change Materials (PCMs)}

Phase change materials are "latent" heat storage materials that undergo a phase transition between liquid and solid that occurs isothermally upon melting (heat storage) or solidifying (crystallization recovery). During phase transition from solid to liquid, PCMs store thermal energy in the form of latent heat by an endothermal process that dissolves the PCM's chemical bonds, and release it exothermally when being cooled to recover its solid state $[55,81,82]$. PCM then is said to act as a thermal storage [83]. The corresponding phase transition of PCM is illustrated in Figure 2.

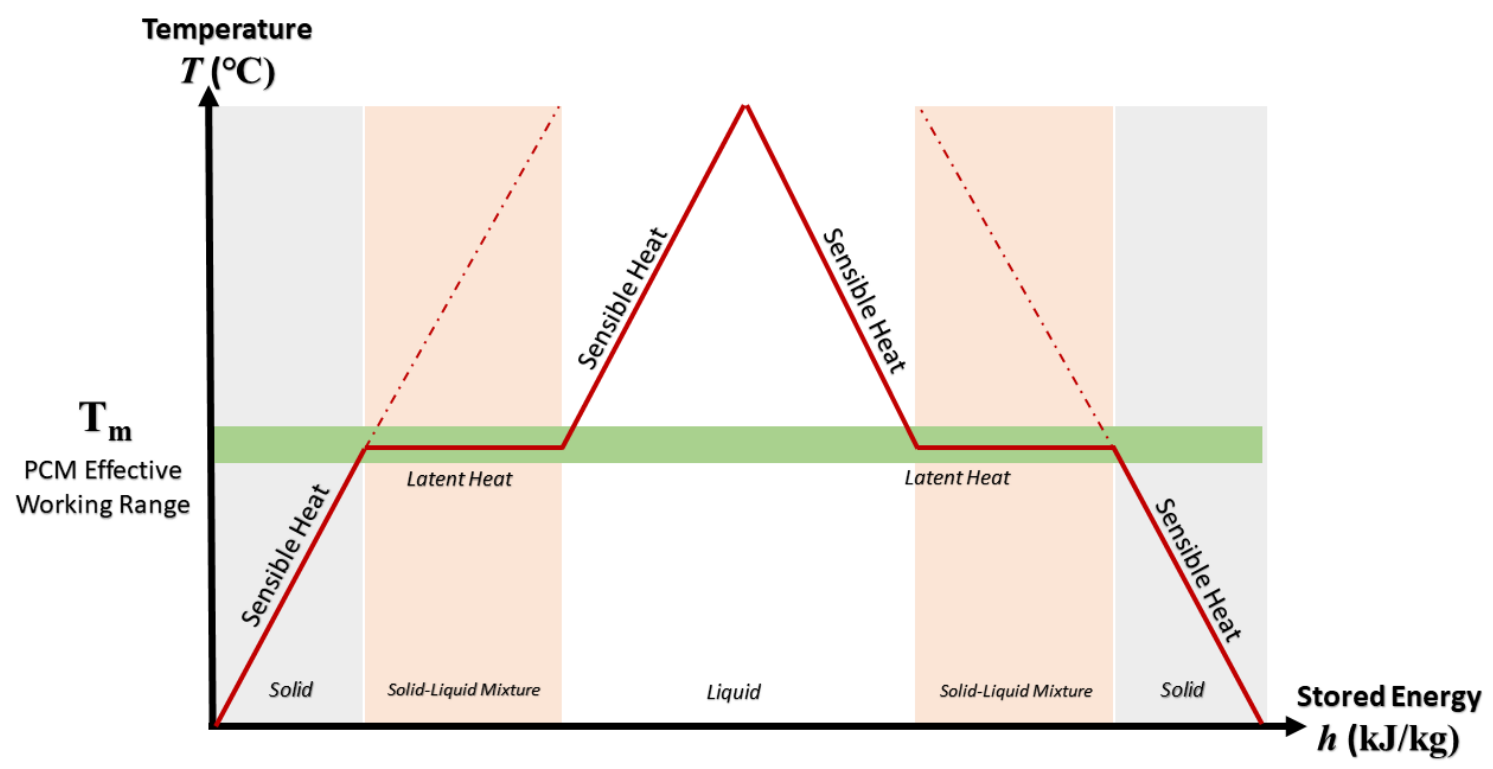

Figure 2 PCM phase change transition. 
Historically speaking, the evolution of PCM as TES combined to building applications for energy conservation was first reported by Barkmann and Wessling [84] on 1975 and then studied by Telkes [85] and lane [86] on 1980, while the first study on nano-PCM was conducted on 2005 by Elgafy and Lafdi [87]. Despite the expected problems in building applications such as: heat transfer problems, fire retardation, sub-cooling, phase separation, and long-term stability [42] as well as uneven melting, coagulation, and leakage problems; with its significant advantages, illustrated in Figure 3, the use of PCM as LHTES technology became one of the most efficient techniques for storing and releasing thermal energy [44].

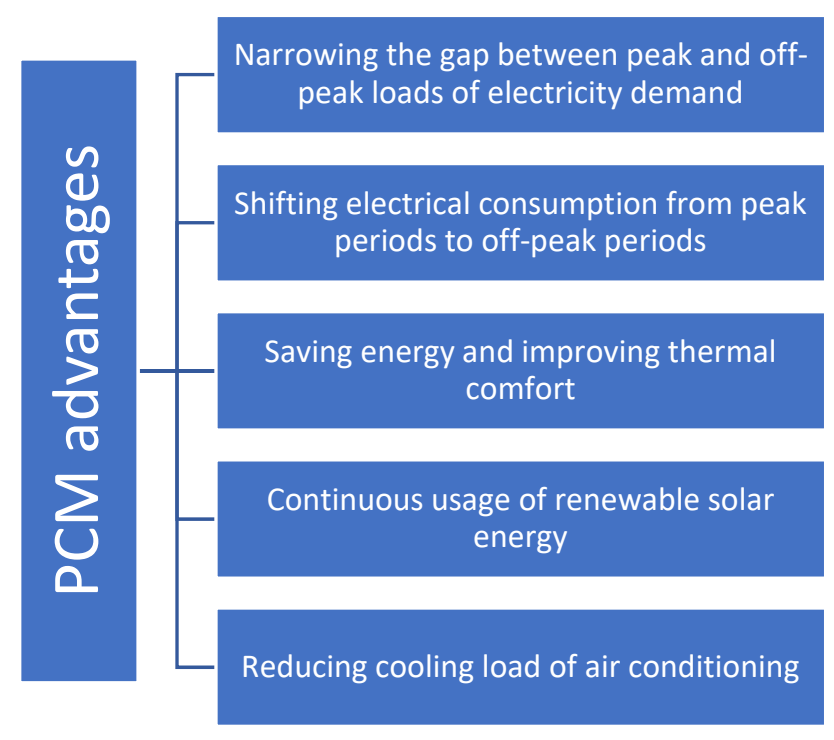

Figure 3 Summary of the advantages of PCMs [17]

\subsection{PCM classification}

Phase change materials that undergo phase change between liquid and solid are classified into three main categories: Organic, Inorganic, and Eutectics [88-90]. These categories are subdivided into further categories based on the chemical components forming the PCM. A generalized helical diagram for the classified PCMs is presented in Figure 4. It is also of great importance to identify the working range of each PCM to meet with the demand while considering its thermal capacity at the same time. Figure 5 shows the variation of melting enthalpy as function of the melting temperature for some common PCMs.

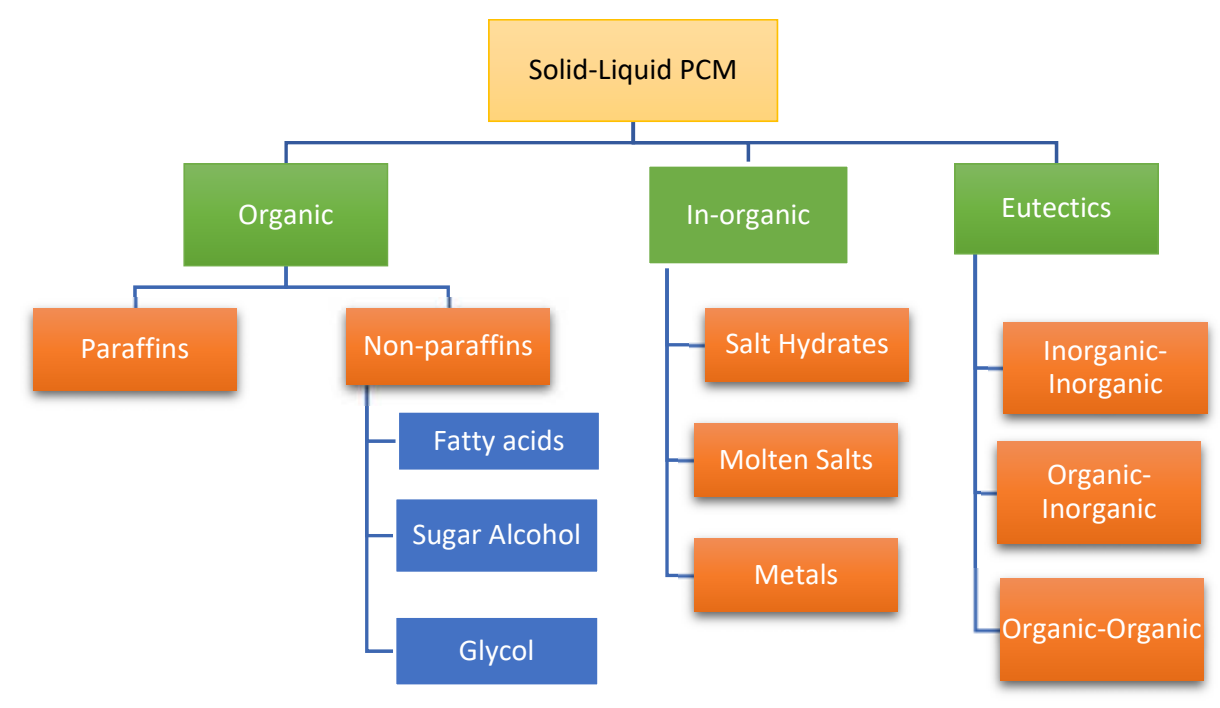

Figure 4 Generalized categories of PCMs [72]. 


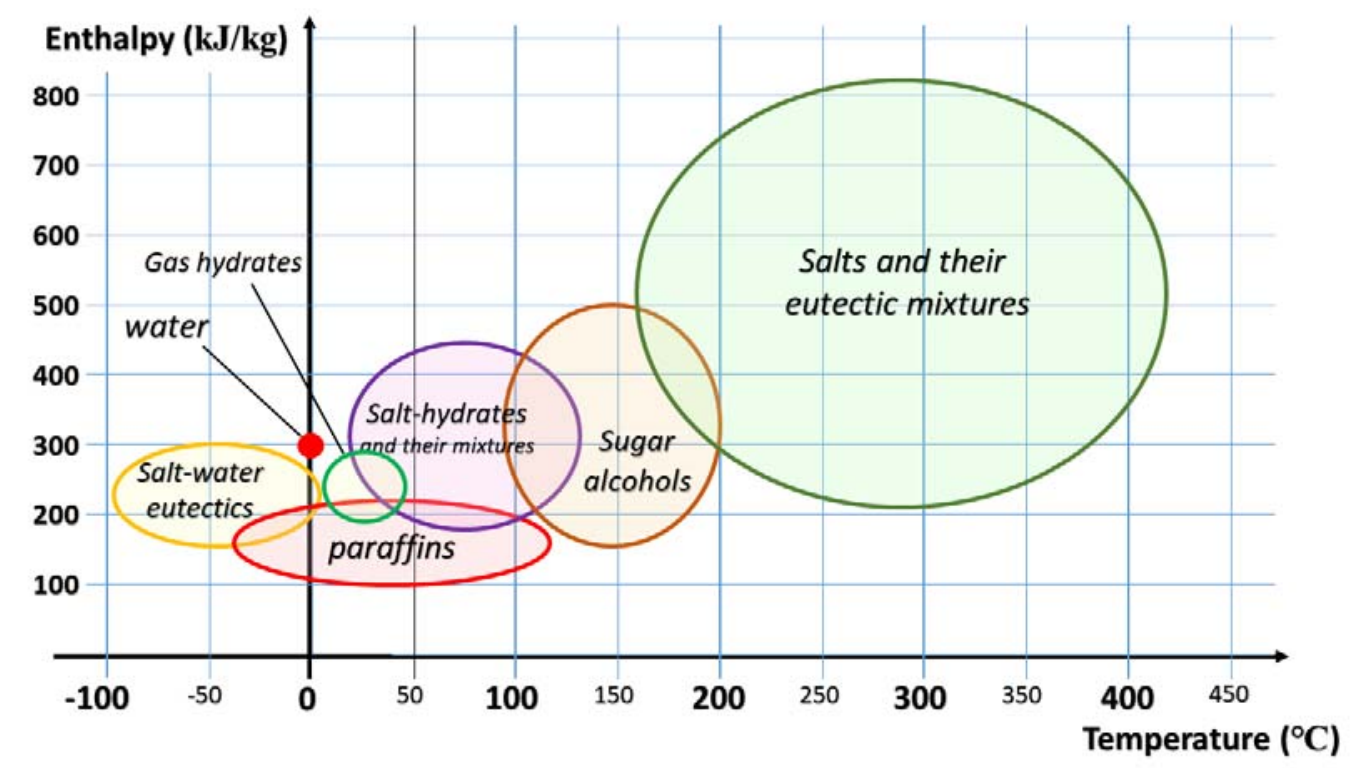

Figure 5 Melting enthalpy versus melting temperature of various PCMs [33].

Organic compounds are subdivided into two main categories: Paraffins and non-paraffins. With their remarkable temperature range that covers the most applications, paraffins seem to have great properties and wide advantages. And since their latent heat is mass-based, they have no phase separation after solid-liquid transition frequent cycles [91]. They also have low vapor pressure, however, they have low thermal conductivity (near 0.2 $\mathrm{W} / \mathrm{m} . \mathrm{K}$ ) [92] and are flammable. The enhancement in thermal conductivity acquired great attention recently; for instance a novel composite PCM was prepared by Yang et al. [93] that is composed of carbonized wood and 1tetradecanol (TD) PCM. The thermal conductivity of the composite PCM was enhanced by $114 \%$ compared to pure TD, reaching a value of $0.669 \mathrm{~W} / \mathrm{m} . \mathrm{K}$. Non-paraffins are either Fatty acids, sugar alcohols, esters or glycols that have promising melting and crystallization properties, however, their costs are higher than those of paraffins by 3 times [94].

Inorganic PCMs are basically salt hydrates (most used), molten salts, or metals and are of higher densities and energy efficiency than organics [95] with the merits of wider transition temperature range, high latent heat and high thermal conductivity [62], besides, they are non-toxic, non-flammable and of low cost, compared to organic PCMs [96]. On the other hand, super cooling, phase segregation, lack of thermal stability, corrosion and decomposition, are drawbacks which dominates their benefits [97].

Eutectics are prepared combinations of two or more low melting temperature components of organics, inorganics, or both, each of which undergo congruent melting and freezing to produce components' crystals mixture upon crystallization [98]. Their best features are not having concern about super-cooling and phase segregation [99]. The main advantage of eutectics over other types of PCMs is that their melting points can be adjusted by combining different weight percentages of components. A summary of the advantages and disadvantages of the different PCM types is presented in

Table 2.

Table 2 Summary of the advantages and disadvantages of three different PCM categories [91,95].

\begin{tabular}{|c|c|c|c|c|c|}
\hline \multicolumn{2}{|c|}{ Organic PCM } & \multicolumn{2}{|c|}{ In-organic PCM } & \multicolumn{2}{|c|}{ Eutectic PCM } \\
\hline Advantages & Disadvantages & Advantages & Disadvantages & Advantages & Disadvantages \\
\hline
\end{tabular}




\begin{tabular}{|c|c|c|c|c|c|}
\hline $\begin{array}{l}\text { - } \text { No super- } \\
\text { cooling } \\
\text { - No phase } \\
\text { segregation } \\
\text { - Low vapor } \\
\text { pressure } \\
\text { - Large } \\
\text { temperature } \\
\text { range } \\
\text { - Self- } \\
\text { nucleating } \\
\text { - Compatible } \\
\text { with } \\
\text { conventional } \\
\text { construction } \\
\text { materials } \\
\text { - Chemically } \\
\text { stable } \\
\text { - Recyclable } \\
\text { - High heat of } \\
\text { fusion }\end{array}$ & $\begin{array}{l}\text { - } \text { Flammable } \\
\text { - Low thermal } \\
\text { conductivity } \\
\text { - Low } \\
\text { volumetric } \\
\text { latent heat } \\
\text { storage } \\
\text { capacity }\end{array}$ & $\begin{array}{l}\text { - Higher } \\
\text { thermal } \\
\text { conductivity } \\
\text { than organics } \\
\text { - Low cost } \\
\text { - Not } \\
\text { flammable } \\
\text { - Sharp phase } \\
\text { change } \\
\text { - High } \\
\text { volumetric } \\
\text { latent heat } \\
\text { storage } \\
\text { capacity } \\
\text { - Low volume } \\
\text { change }\end{array}$ & $\begin{array}{l}\text { - Corrosive to } \\
\text { metals } \\
\text { - Super-cooling } \\
\text { - Phase } \\
\text { segregation } \\
\text { - Congruent } \\
\text { melting } \\
\text { - High volume } \\
\text { change }\end{array}$ & $\begin{array}{l}\text { - Sharp melting } \\
\text { point } \\
\text { - Properties can } \\
\text { be tailored to } \\
\text { match specific } \\
\text { requirements } \\
\text { - High } \\
\text { volumetric } \\
\text { thermal } \\
\text { storage } \\
\text { density }\end{array}$ & $\begin{array}{l}\text { - Limited data } \\
\text { on thermo- } \\
\text { physical } \\
\text { properties } \\
\text { for many } \\
\text { combinations } \\
\text { - High cost }\end{array}$ \\
\hline
\end{tabular}

\subsection{PCM selection criteria}

It is very critical for PCM selection, to be utilized as LHTES materials in buildings, to consider some important contemplations that must be studied. Methodology of selecting the suitable PCM depends on several guidelines. Deciding what melting temperature to be used is the initial start, where, it is recommended that the melting temperature range be in the range of $15-30^{\circ} \mathrm{C}[44]$ or $20-32^{\circ} \mathrm{C}$ [55] for building applications, which are the range of thermal comfort. However, PCMs have to possess certain anticipated thermo-physical, kinetic, chemical, technical and economic characteristics that are listed as follows [61,91,100-102]:

-Thermo-physical properties: In addition to having the desired temperature range mentioned previously, PCMs ought to have high latent heat of fusion, high specific heat, high conductivity, high density, small phase transition volume changes, cycling stability, low vapor pressure at operational temperature and congruent melting.

-Kinetic properties: They are two: High nucleation rate (so liquid phase super-cooling is evaded) and high rate of crystal growth (achieving optimum recovery from storage system).

-Chemical properties: Complete reversible cycle, chemically stable with no degradation after a large number of freezing/melting cycles, chemically compatible with construction/encapsulation materials, no corrosiveness, not toxic, not explosive and anti-flammable.

-Economic properties: Cost effective and commercially available for large-scale practice.

-Environmental properties: Low environmental impact, non-polluting through service life and having a recycling potential.

However, the number of PCM attaining all the desirable properties is null [100], and compromising to a definite point might be made to some cases [61]. For that, Yang et al. [103] proposed a method for PCM selection established on the basis of multi-criteria decision making as an attempt to overcome the conflicting characteristics of PCMs. The method proved to address reasonable conclusions upon PCM selection for specified applications.

\subsection{PCM Characterization Techniques}


Several measurement techniques are developed by the scientific community including [13,29]: (1) Differential Scanning Calorimetry (DSC), (2) Differential thermal analysis (DTA), and (3) T-history method for thermophysical properties; (4)Thermal cycling analysis and (5) Fourier Transformed Infrared Spectroscopy (FT-IR) for chemical properties; (6) Scanning Electron Microscopy (SEM) for microstructure observation; (7) Thermo Gravimetric Analysis (TGA) for thermal stability; And, (7) Hot disk apparatus for thermal conductivity measurement.

\subsubsection{Differential Scanning Calorimetry}

DSC is one of the most prominent tests used for measurements of time, temperature and heat absorbed/released during the phase transition process of PCMs. The technique allows scientists to measure the transition temperature, enthalpy and specific heat of PCMs. In this test, small samples of studied PCM and a reference material undergo controlled cooling and/or heating such that their temperature is kept equal while their linear increase/decrease [104]. Different types and operation modes of DSC are illustrated in Figure 6.

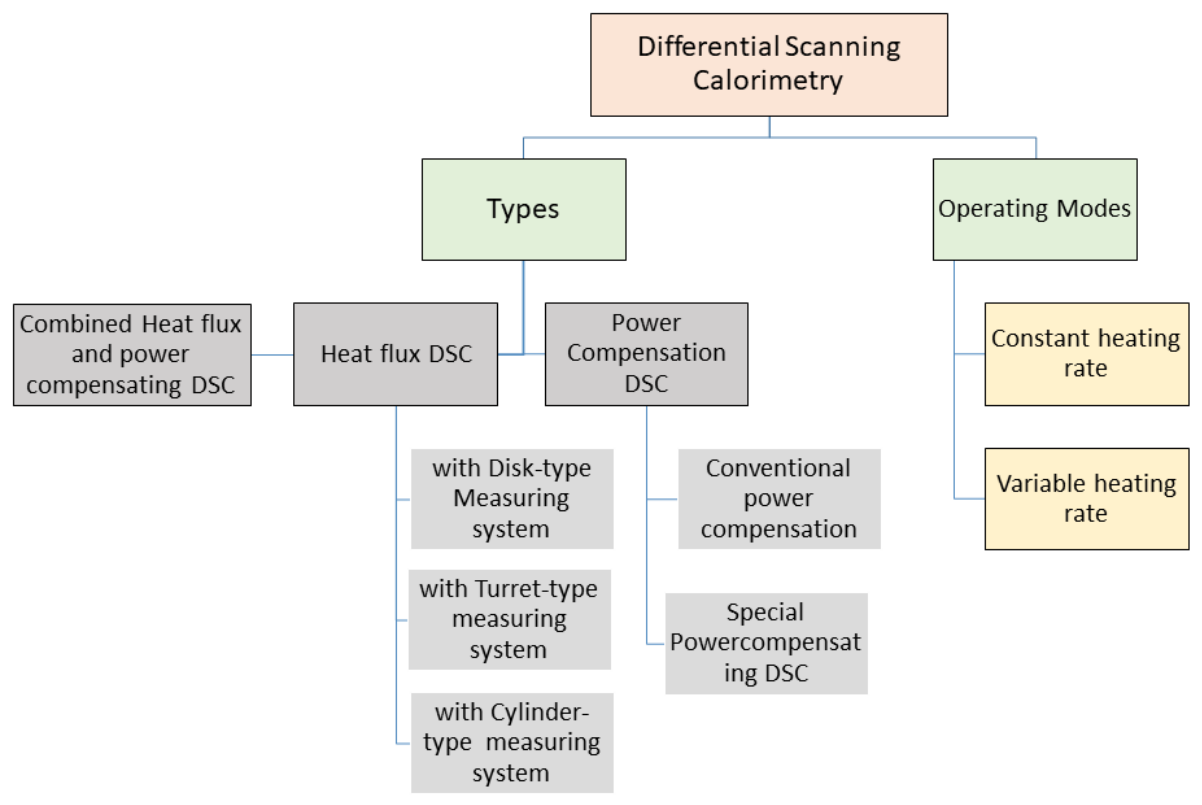

Figure 6 DSC types and operating modes as summarized by G. Höhne et al. [105].

\subsubsection{Differential Thermal Analysis}

DTA is applied to measure the change in temperature difference as a function of temperature or time, between the sample being studied and the inert reference one, while being subjected to a controlled temperature program [105]. It is mainly composed of: a sample holder, thermocouple sensors, furnace, temperature controller and a recording system.

\subsubsection{T-history method}

The original T-history methoud was established by Yinping in 1999 [106]. The technique is based on recording the temperature of the PCM sample and a well-known reference, normally water as function of time. Generally, using the T-history method, heat capacity, fusion and solidification enthalpies and phase change temperatures are determined [101].

\subsubsection{Fourier Transformed Infrared Spectroscopy}

Fourier transform infrared spectroscopy (FT-IR) is a method used to acquire an infrared spectrum of absorption, emission, photoconductivity or Raman scattering of a solid, liquid or gas [107].

\subsubsection{Scanning electron microscopy}


An important property of a PCM is its morphology and particle size. SEM helps in detecting the particle size and determining the shape of the particles especially for micro-encapsulated PCMs such as cement-based PCM composites [108]. Morphological microstructures investigation is important to determine the compatibility of composite PCMs, and the ability of a supporting material to absorb liquid PCM in the preparation processes of such composites [109].

\subsubsection{Thermogravimetric Analysis}

Thermogravimetric analysis (TGA) is a thermal analysis that permits the measurement of the mass of the PCM over time as its temperature changes at a constant heat rate. It can be either a Top-loading test where the sample is held above the balance via a stem support rod, or a Bottom-loading test where the sample is supported via a hang-down below the weighing scale. It allows the determination of the chemical composition of the PCM to predict its thermal stability.

\subsubsection{Hot disk apparatus}

An engrained Hot Disk Transient Plane Source (TPS) method is capable of performing a quick, precise and nondestructive testing of Thermal Conductivity and Thermal Diffusivity (directly measured); and Specific Heat Capacity of variable materials can be calculated from the former two.

\section{Use of PCM-TES for Heating Applications in Buildings}

PCMs applications are suitable for both new buildings and retrofitting of existing ones [91]. Their integration into building materials by various encapsulation techniques is increasing worldwidely [110]. Literature including both experimental and numerical analysis are presented in this section. PCM-TES can be used for heating, cooling or for both heating and cooling which is referred as hybrid systems. Each mode is subdivided into passive and active categories. Heier et al. [42] states that the difference between active and passive systems is the driving force of charging and discharging the store, where active storage utilizes pumps or fans however passive storage depends only on temperature difference.

\subsection{Heating passive methods}

The application of PCM for passive heating is mainly directed to the adaptation of PCM to building envelope starting with walls: particularly in construction materials such as building bricks, stones and concrete, as well as plastering mortar, with special focus on PCM wallboards. Floors and ceilings are also targets for designers in PCM integration for buildings. Other designs include the application of Trombe walls and Solar facades employing PCM for thermal energy storage.

\subsubsection{Walls, wallboards, floors and ceilings}

Mourid et al. [89] tested the thermal behavior of two full-scale real prototypes in the Mediterranean climate of Casablanca, Morocco. The experimental analysis aimed for measuring the indoor, wall surface, ceiling surface, and outdoor ambient temperatures as well as the heat flux through the wall and ceiling. These measurements covered a reference prototype (shown in Figure 7) and another one equipped with $5.26 \mathrm{~mm}$ thick PCM Energain ${ }^{\circledR}$ wallboards. It was shown that the temperature of the PCM room was higher than that of the reference one by a maximum deviation of $7.3^{\circ} \mathrm{C}$. Moreover, it was concluded from the results that the stratification in the room was demolished by the PCM, and the thermal losses are decreased by $50 \%$ across the ceiling emphasizing that the placement of PCM in the ceiling is more efficient than in the wall. Also, an average energy consumption reduction of $20 \%$ was accomplished, with $6 \mathrm{~h}$ shift between entering and leaving flux densities through PCM. 

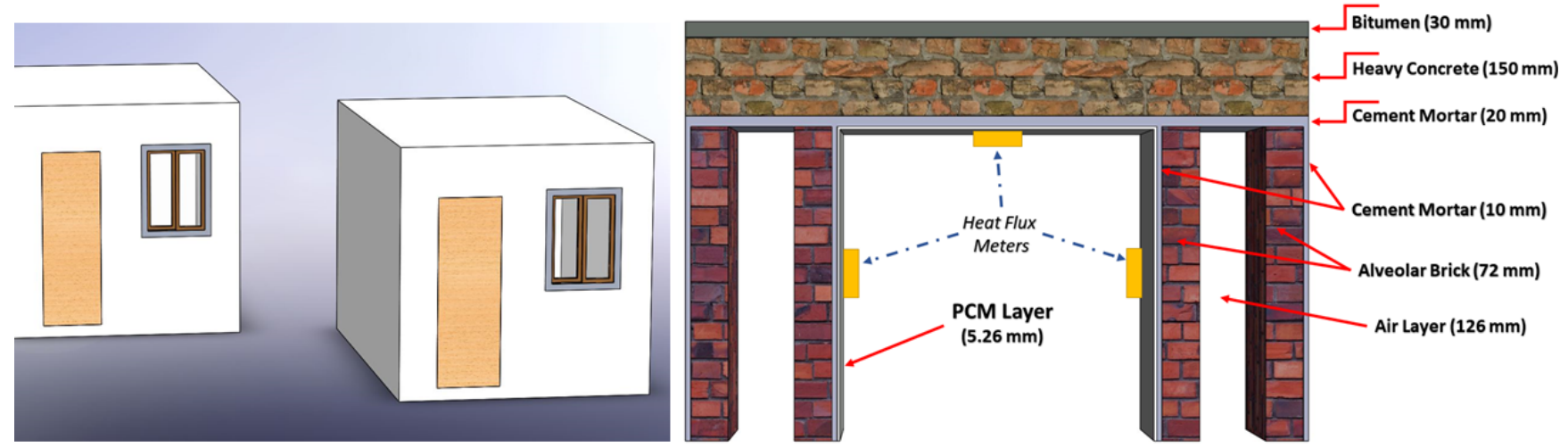

Figure 7 Illustrations of Real scale prototype (left side) and wall and ceiling composition and emplacement of the flux meters on the walls of the first tested period (right side) [89].

Faraji [111] modeled a wall containing PCM at its center layer with heavy concrete on both external and internal sides. The enthalpy method was utilized to predict numerically the thermal behavior of the novel wall being subject to weather conditions of Casablanca, Morocco. Results showed a reduction in indoor temperature fluctuations coupled to a shift in temperature oscillations for the PCM wall compared to reference concreate wall. However, the author concluded that sub-cooling and overheating are major threats for PCM if it doesn't undergo an immediate phase change, thus special care must be taken into account while choosing the right PCM. Li et al. [126] prepared two sided insulated test rooms for the sake of studying the thermal performance of building envelope with and without the integration of PCM on its north wall exterior. It was inferred from the obtained results that PCM is able to improve indoor thermal environment, reduce heating duration, and reduce the consumption of heating energy. Karim et al. [112] developed a hollow concrete floor panel that utilizes shapestabilized polymer composite PCM enclosed in its cavities to increase the floor thermal inertia (Figure 8). The floor was designed as a construction material including the PCM in its body thus removing the leakage problem. Results proved that adding PCM to the floor design increases its ability to store thermal energy, and shifts the peaks to day hours ensuring stability of indoor temperature.

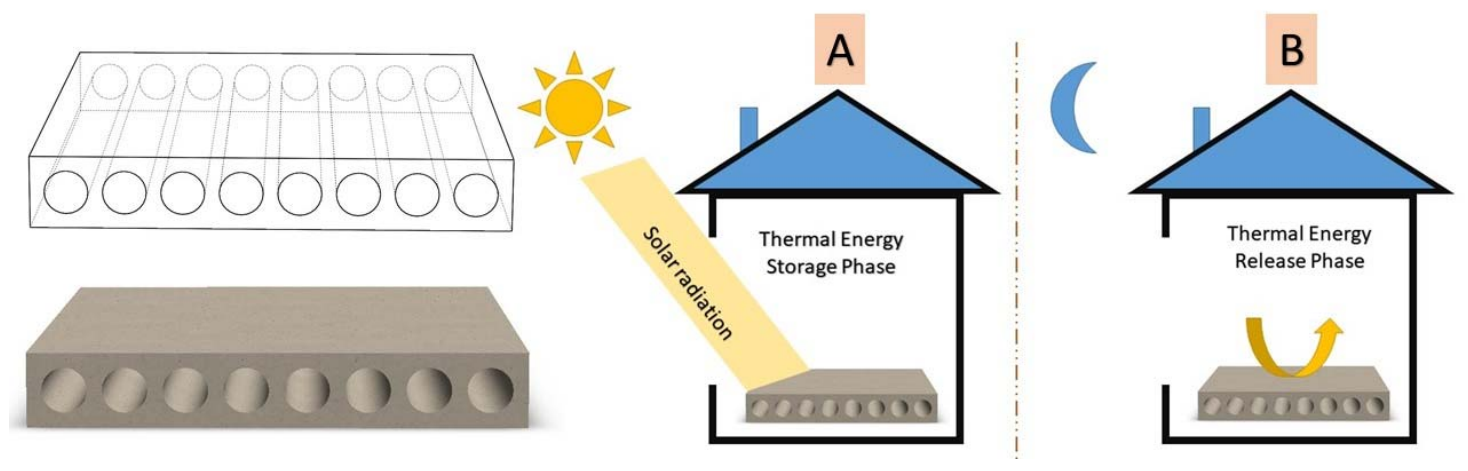

Figure 8 The new floor panel with hollows to contain PCM and its functioning during day and night [112].

Kim et al. [113] proved in his study that the installation position and area are important factors that must be considered in designing LHTES systems in buildings alongside PCM amount. Their study covered the application of shape stabilized PCM sheets in walls, floor and ceiling in Japanese climate for three identical test huts: A (no PCM, reference), B (4 layers of SSPCM sheets in floor) and C (floor, wall and ceiling containing one sheet of SSPCM each). After validating the results with a simulation model using EnergyPlus ${ }^{\circledR}$, the authors managed to run a simulation for 21 cases in 7 Japanese climates. Results showed that the annual heating load was lower for Hut B and Hut C by $8 \%-42 \%$ and $19 \%-54 \%$ than the reference hut A, respectively.

A numerical investigation for the thermal performance of a building brick containing PCM was established by Kant et al. [114]. The model was based on implementing cylindrical cavities in a brick that are considered for 
PCM encapsulation. To have a wide view on the thermal behavior of the PCM and its advantages in improving the performance of such construction material, three bricks were considered: A reference brick having no PCM and no cylinders, brick containing PCM and another one containing air in its cylindrical cavities. Also, the study covered a comparative analysis for three different PCMs: Paraffin $\left(\mathrm{T}_{\mathrm{m}}=28.2^{\circ} \mathrm{C}, \mathrm{L}_{\mathrm{h}}=245 \mathrm{~kJ} / \mathrm{kg}\right), \mathrm{RT} 25$ $\left(\mathrm{T}_{\mathrm{m}}=26.6^{\circ} \mathrm{C}, \mathrm{L}_{\mathrm{h}}=232 \mathrm{~kJ} / \mathrm{kg}\right)$ and Capric acid $\left(\mathrm{T}_{\mathrm{m}}=32^{\circ} \mathrm{C}, \mathrm{L}_{\mathrm{h}}=152.7 \mathrm{~kJ} / \mathrm{kg}\right)$. Results confirmed that Capric acid shows higher effectiveness compared to other PCMs. Also, it was found that up to $8.31 \%$ reduction in heat flux were achieved by PCMs.

\subsubsection{Trombe walls}

Kara and Kurnuç [115] investigated the performance of two Trombe wall constructed in corporation with Triple pane windows in two test facilities sharing the same side and facing south in Erusurm, Turkey (Figure 9). GR35 PCM was placed within the first wall and the other utilized GR41. Results show that the ratio of solar energy gain over by PCM walls to heat load varied between $4 \%$ and $70 \%$, with a daily overall efficiency 0 f $20 \%$ to $36 \%$ for PCM walls. Besides, it was found that GR35 is more efficient than GR41 in such application. A numerical investigation of a composite Trombe solar wall integrated with microencapsulated PCM was performed by Leang et al. [116] using Dymola Modelica software. After validating the numerical model with preceding experimental results of a concrete storage wall, the model was used to investigate a composite solar wall where the concrete storage wall is replaced with mortar mixed with microencapsulated PCM (Figure 10). Results showed that compared to concrete storage wall, large capacity of recovered heat was achieved the MPCM storage wall. Furthermore, the $4 \mathrm{~cm}$ mPCM storage wall triggered a phase time delay almost 4 times shorter than that obtained of the reference wall.

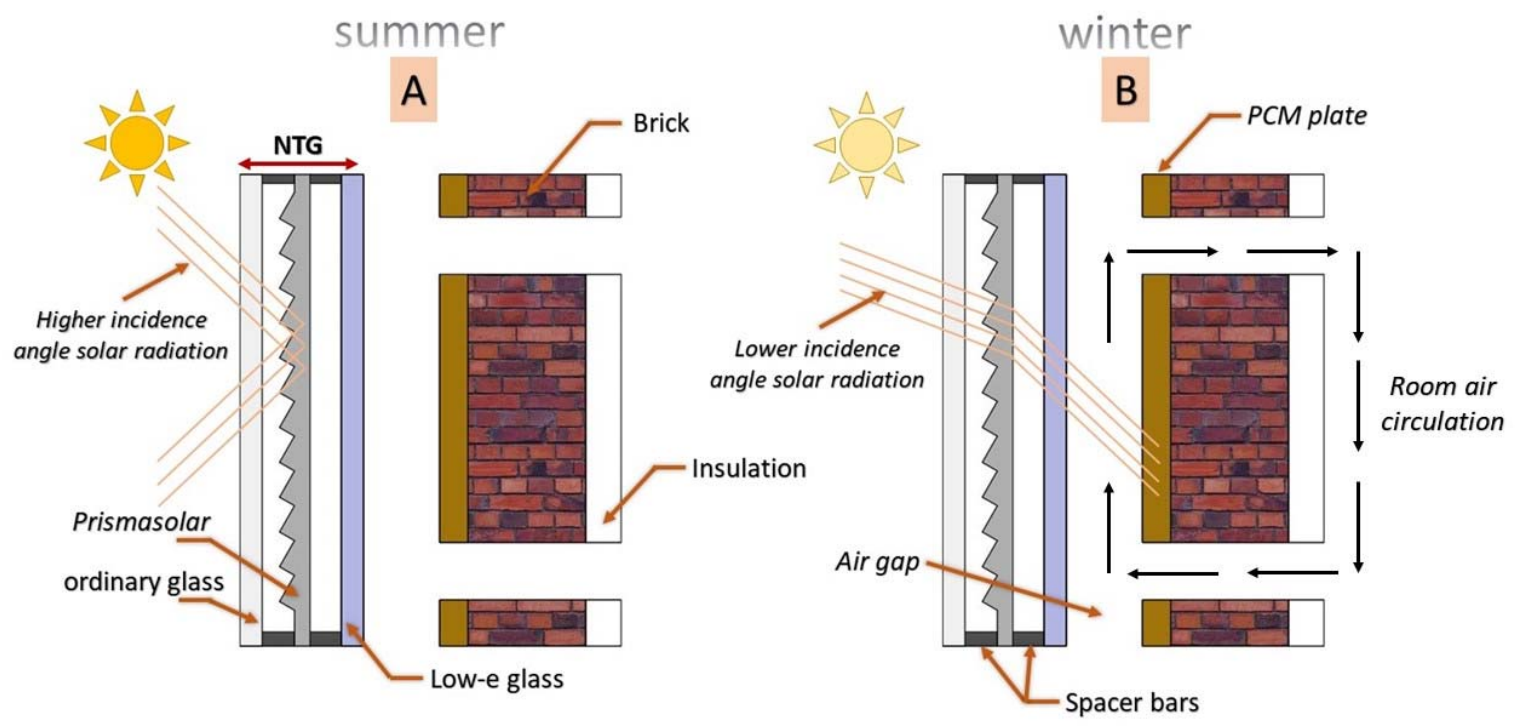

Figure 9 The working principle of the designed Trombe wall coupled with the TW [115]. 


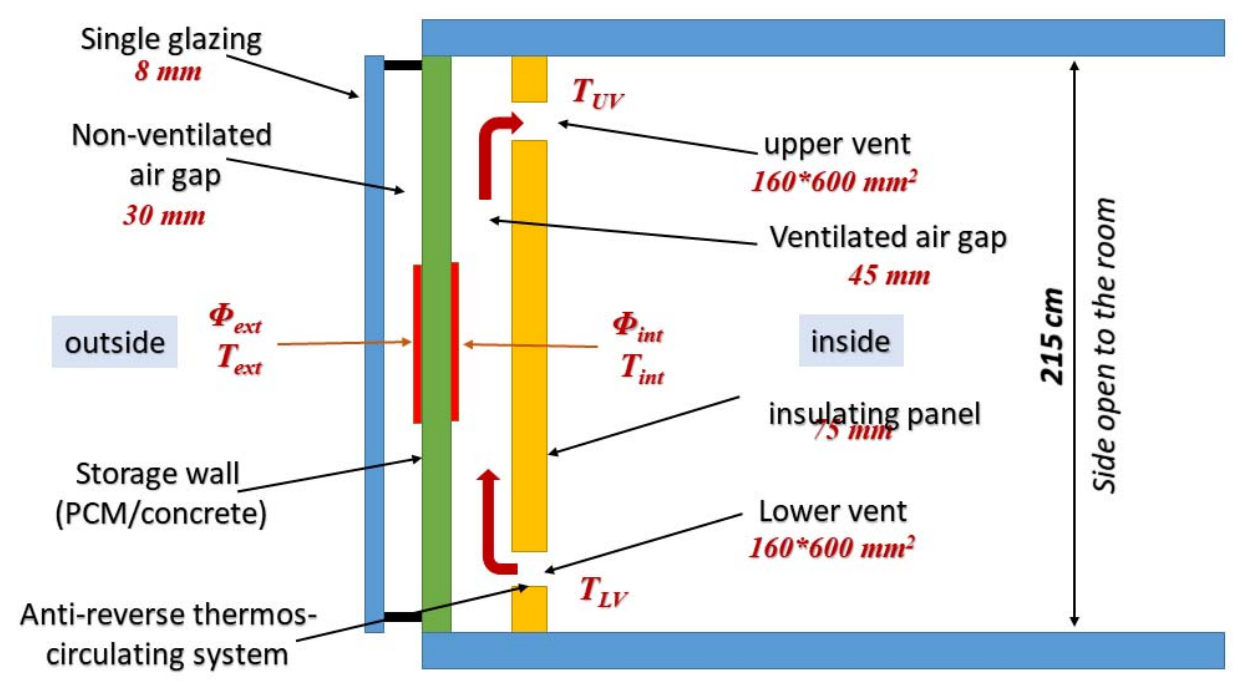

Figure 10 Vertical cross section of the Trombe wall system [116].

$\mathrm{Hu}$ et al. [117] reviewed the Trombe wall applications in buildings during recent 15 years. Trombe walls were categorized into two sets: cooling-based and heating-based. The developed types throughout the years are summarized in the helical diagram presented in Figure 11.

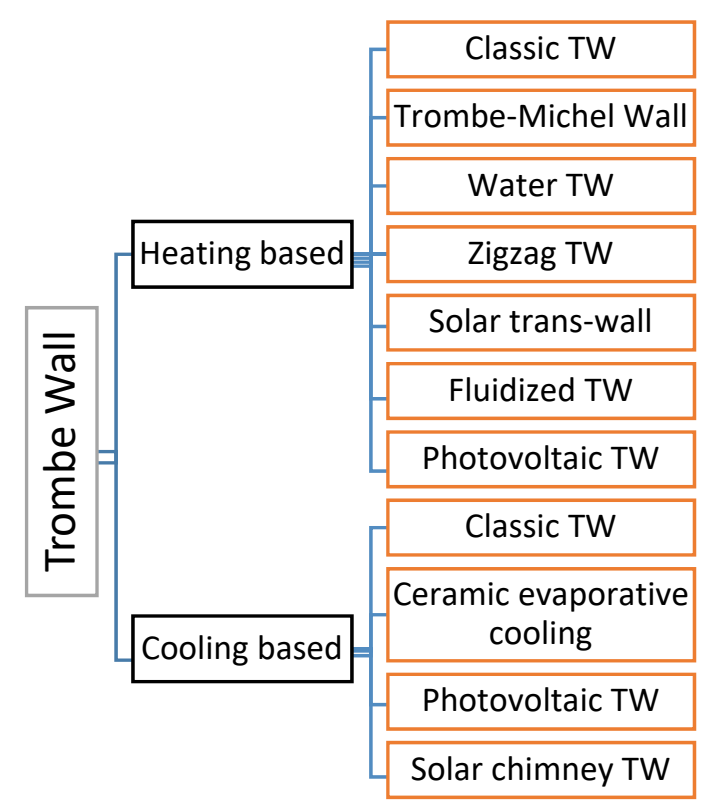

Figure 11 Classification of trombe walls for heating and cooling applications [117].

\subsubsection{Solar facades}

Thermal performance of a ventilated solar façade with macro-encapsulated PCM placed at its air cavity was experimentally investigated by Gracia et al. [118] in Spain. Two identical house cubicles, where one is with a ventilated façade incorporating SP22 PCM plates and the other as a reference. Results employed that a daily increase in the temperature from $9{ }^{\circ} \mathrm{C}$ to $18{ }^{\circ} \mathrm{C}$ under severe winter conditions is achieved with the ventilated facade incorporating PCM during free-floating mode. Moreover, the free-floating experiments demonstrated that the use of HVAC system is almost not necessary during the mild winter period. Liu et al. [119] investigated the thermal performance of a non-ventilated multilayer glazing facade filled with phase change material. The study included the installation of three test facilities as shown in Figure 12, and a model was prepared to obtain valuable results for direct analysis. Results showed that an increase in interior surface temperature and temperature time 
lag when increasing PCM thickness which enhances thermal comfort. However, the authors recommended a maximum limit of $20 \mathrm{~mm}$ thick PCM layer that must not be passed due to the respective decrease in solar transmittance.
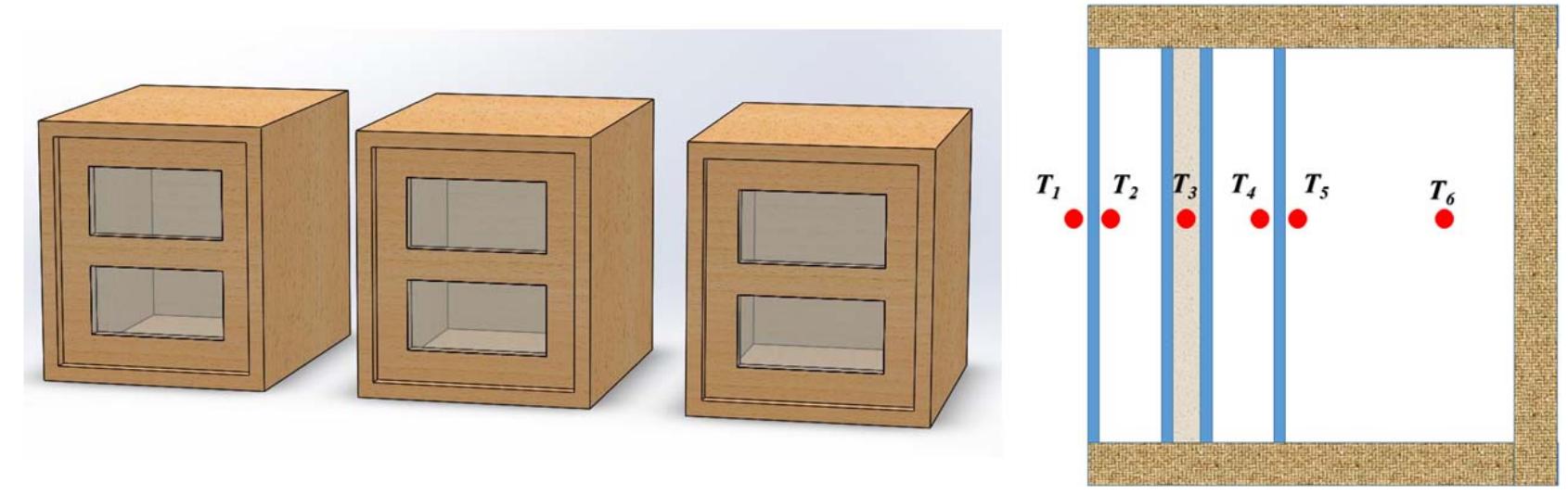

Figure 12 Test facilities on the left, and the schematic diagram of the solar façade on the right [119].

\subsection{Heating active methods}

Starting from the most popular, active heating applications using PCM are: underfloor radiant heating with PCM including: electrical heating systems, hydronic water system and hot water capillary mats, solar water heaters, solar air heaters, ventilated façades, solar heat pumps, heat exchangers, HVAC systems and solar domestic hot water systems.

\subsubsection{Underfloor heating with PCM}

For evolving a proficient zone space, it was anticipated that radiant or convective heating systems play a great role [120]. Thermal performances of hot water floor panel with different heating pipes: polyethylene coils (PE pipes) and capillary mat (CAP mat), incorporated with different TES materials (sand and PCM) were experimentally studied by Zhou et al. [121]. Four floor configurations utilizing the different possibilities regarding heating coil and TES used were studied. The results showed that CAP mat provided more uniform vertical temperature distribution, higher heat storage rate, and required shorter time to reach comfort indoor temperature during charging process as compared to PE-pipes. Also, it was proven that the discharging time of the PCM storage (latent) was twice that of sand (sensible) which ensures that PCM is highly efficient as a thermal mass for floor heating system that releases heat to retain the indoor temperature. Energy savings, economic benefits, and cost-effective performance of HCE-SSPCM used in underfloor heating systems, as well as the effect of SSPCMs thermal conductivities on their performances, were the topics discussed by Cheng et al [122]. The authors performed both experimental and numerical analysis, where at the numerical level, it was shown that the heat leakage through insulation decreases with the increase of PCM's thermal conductivity, however, the heat leakage rate receives no effect when the enhancement of thermal conductivity of the SSPCM exceeds $1 \mathrm{~W} / \mathrm{m} . \mathrm{K}$. And, with a high thermal conductivity PCM in the floor, a better comprehensive performance with a thinner insulation layer can be achieved. Experimentally speaking, two identical test rooms located in Anhui Province, China, were prepared. Heat conduction enhanced SSPCM plates were installed above the electrical heater in the $1^{\text {st }}$ room, while the other room with no PCM contained the electrical heater and a conventional AC system for comparison. Results show that the phase change energy storage system had the lowest economic consumption compared to the other two heating systems, and was proved to have more economic benefits and more cost-effective performance. Besides, a CFD simulation showed a great matching with the experimental results.

The addition of passive systems in attempting to increase the active underfloor heating systems is quite a great idea that require careful research for optimizing the best combination of active and passive systems. Several studies have focused on adding PCM to walls and ceilings to assist the underfloor active PCM-TES system. Limited studies on underfloor heating systems incorporating PCM influenced Barzin et al. [123] to perform a 
peak load shifting application for underfloor heating by integrating PCM into the floor with the incorporation of PCM wallboards. The experiments were conducted in Tamaki Campus, University of Auckland, New Zealand, on two identical huts. The first hut was considered the reference and was heated by an AC unit, and hut 2 contained the PCM impregnated in gypsum wallboards above an electric heater placed in the floor with the corporation of PCM wallboards (DuPont Energain ${ }^{\circledR}$ ) placed at the internal faces of the hut. Results showed a successful morning peak load shifting. However, during the peak load evening period, the results were insignificant. On the other hand, an improvement in the results for the five-days period, influenced by the installation of the PCM wallboards, was promising regarding the evening. The study presented a total cost saving of $18.8 \%$ corresponding to an energy saving of $28.7 \%$, with the maximum achieved cost and energy savings being $35 \%$ and $44.4 \%$, respectively. Finally, the authors consisted on the importance of the proper selection of PCM melting temperature that best meets thermal comfort requirements. Devaux and Farid [17] validated the experimental results obtained from experiments done on the two huts presented in the previous study, numerically via EnergyPlus software after modelling the rooms with PCM underfloor heating system being installed. The PCM hut 2 and its model design is assembled as shown in Figure 13, having the aforementioned paraffin-based PCM impregnated gypsum board. The authors declared that the use of EnergyPlus is reliable in predicting energy consumption when incorporating PCM underfloor heating systems. Moreover, results emphasized that the use of higher melting point PCM with underfloor heating system allowed significant peak load shifting whereas comfort demands are accomplished with lower melting point PCM in walls and ceilings. For the 10 days' study period, a cost saving of $42 \%$ corresponding to an energy saving of $32 \%$ was achieved. Authors finally recommended for further work the study of possibilities for predicting suitable temperature ranges for controller change before the next day.

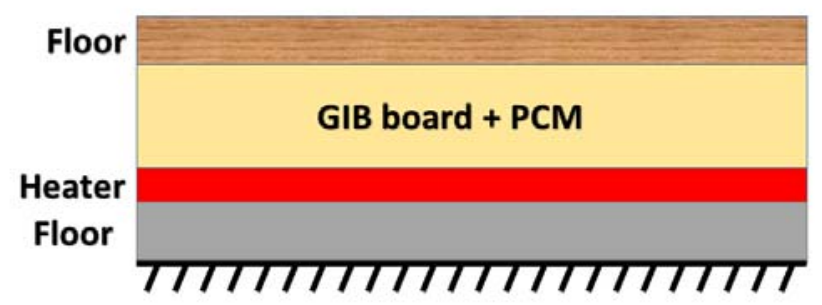

Figure 13 Underfloor heating system layout [17].

Lin et al. [124] prepared a model for simulating an underfloor electrical heating system with shape-stabilized PCM, and after its promising results, they followed it by an experiment [125] which was prepared to test the effectiveness of SSPCM in underfloor electric heating system. The design was based on placing $12 \mathrm{~cm}$ thick polystyrene insulation at the base of the floor with electric heaters, $1.5 \mathrm{~cm}$ thick PCM with some wood supporters between the PCM plates above it respectively. An air gap is left with a $1 \mathrm{~cm}$ thickness above the PCM layers, and finally an $8 \mathrm{~mm}$ thick wooden floor. Their results were quite promising: More than half of total electric energy was shifted from peak position to off-peak position, providing economic benefit due to different electricity tariff between day and night in Beijing, China. Another research done by Yinping et al. [126] included the use of PCMs having melting points of $20^{\circ} \mathrm{C}$ and $60^{\circ} \mathrm{C}$. The graphed results showed that the optimal melting temperature for PCMs when used with electric underfloor heating system is $40^{\circ} \mathrm{C}$, and optimal heat of fusion for Paraffin used is between $120 \mathrm{~kJ} / \mathrm{kg}$ and $160 \mathrm{~kJ} / \mathrm{kg}$.

\subsubsection{Solar water heater}

Huang et al. [127] performed a numerical analysis and validated it experimentally for a new design of a solar water heating system utilizing capillary pipes placed above and below a prefabricated concrete skeleton having 169 vacancies occupied by macro-encapsulated capric acid (Figure 14). ANSYS software was used to model the floor and two sided identical $2^{\text {nd }}$ floor rooms were prepared, in Shenyang JianZhu university, northern China, for the experimental investigation: the $1^{\text {st }}$ with PCM floor and the other with concrete. Results showed that the floor's energy storage capacity is greatly enhanced with the benefit of saving water tank's space. $37677.6 \mathrm{~kJ}$ was released by the floor for $16 \mathrm{~h}$ while the water circulation is stopped during sunset with the floor surface temperature maintained above $20{ }^{\circ} \mathrm{C}$ in case of PCM, which was equivalent to $47.7 \%$ of energy supplied by solar water. A 
numerical study by Bouhal et al. [48] was conducted to investigate the effect of adding PCM to solar water heaters (Figure 15). The study focused on comparing the simulation results of both methods: Enthalpy method and the apparent heat capacity method. It was shown that Enthalpy method requires more computing time if compared to the second method, where the latter is best adapted if the specific heat capacity form of the PCM during charging and discharging of the PCM is knownZhou et al. [210] investigated the thermal performance of a storage tank filled with PCM spherical capsules utilized in a centralized solar hot water system. The authors used two PCMs of different melting temperatures $\left(55^{\circ} \mathrm{C}\right.$ and $\left.60^{\circ} \mathrm{C}\right)$ and their results inferred that the use of the higher melting temperature PCM is more efficient in such case. Nevertheless, an obvious enhancement in the solar fraction was achieved with the use of the two PCMs.

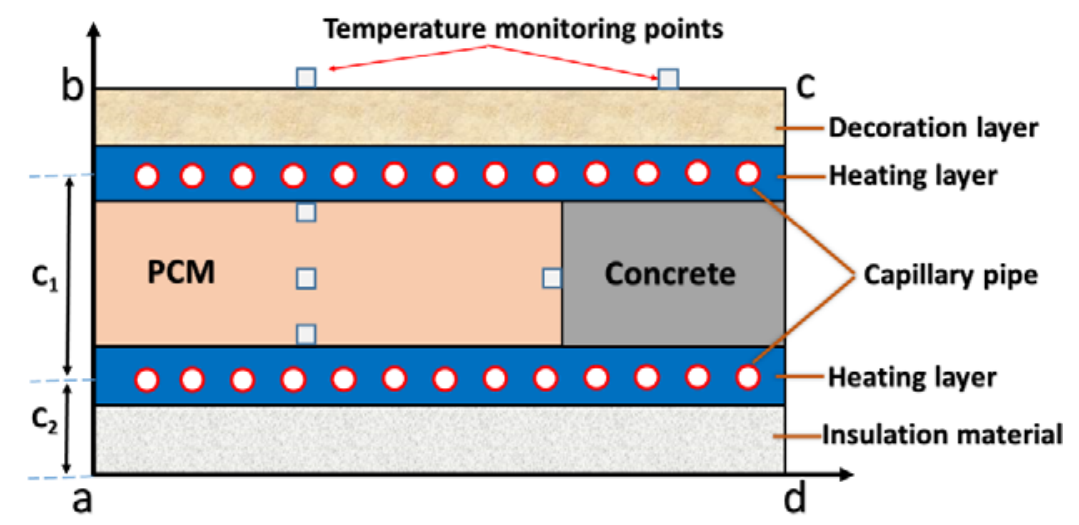

Figure 14 Cross-section of the floor with PCM for the design of SWHS [127].

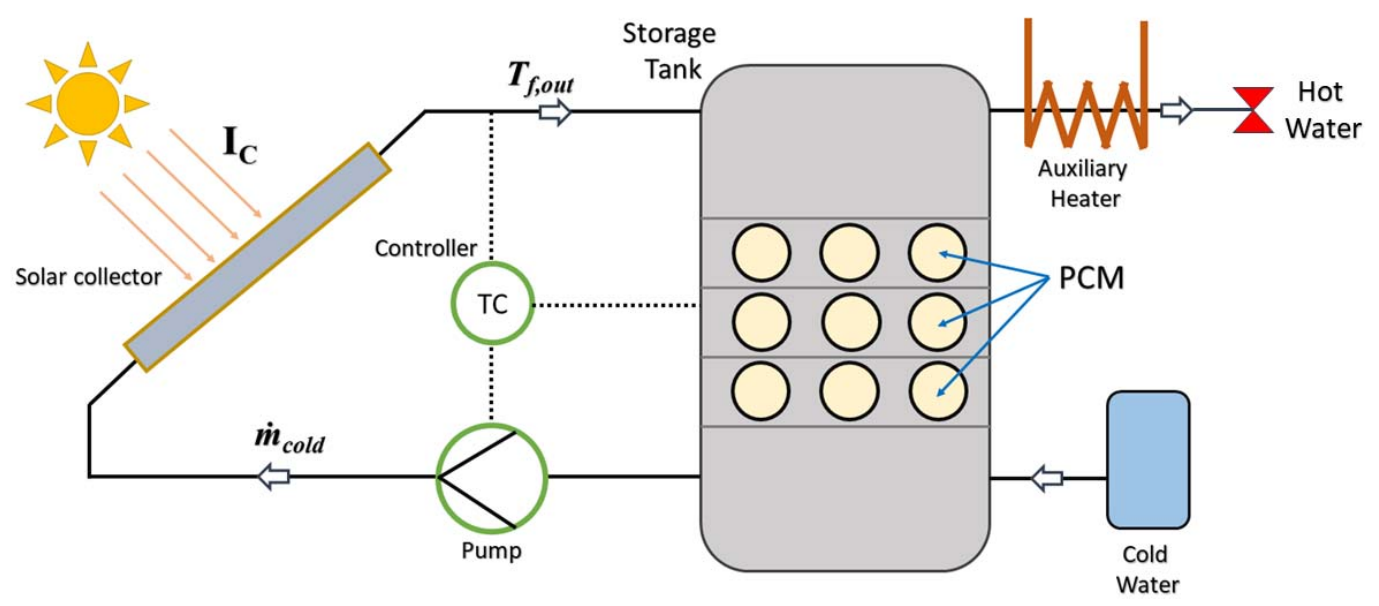

Figure 15 The heating storage unit with PCM used in the solar water heater system [48].

\subsubsection{Solar air heater}

For solar air heater (SAH) applications using PCM as thermal storage system, spherical encapsulation of PCM forming a packed bed LHTES system proved to have the advantage of higher storage density, configurational simplicity and large ratio of surface to volume. A study by Esakkimuthu. [60] who performed experiments on the charging and discharging characteristics of a SAH packed with HC58 PCM as a TES system in India, focused on the effect of different flow rates on the TES system performance. Kabeel et al. [128] carried out an experimental investigation of flat and v-corrugated plate SAHs with built-in PCM as thermal energy storage material illustrated in Figure 16. The integrated SAH with paraffin wax as PCM was designed and tested under prevailing weather 
conditions of Tanta city, Egypt. Results confirmed that upon using PCM, the outlet temperature of the vcorrugated plate $\mathrm{SAH}$ was higher than ambient temperature by $1.5-7.2^{\circ} \mathrm{C}$ during $3.5 \mathrm{~h}$ after sunset compared with $1-5.5^{\circ} \mathrm{C}$ during $2.5 \mathrm{~h}$ after sunset for flat plate $\mathrm{SAH}$ when the mass flow rate was $0.062 \mathrm{~kg} / \mathrm{s}$. where at this flow rate, the daily efficiency of the v-corrugated SAH using PCM was higher by $12 \%$ than the corresponding ones without using the PCM, 15\% than the corresponding values when the flat plate was used with PCM and $21.3 \%$ than the corresponding values when the flat plate was used without PCM.
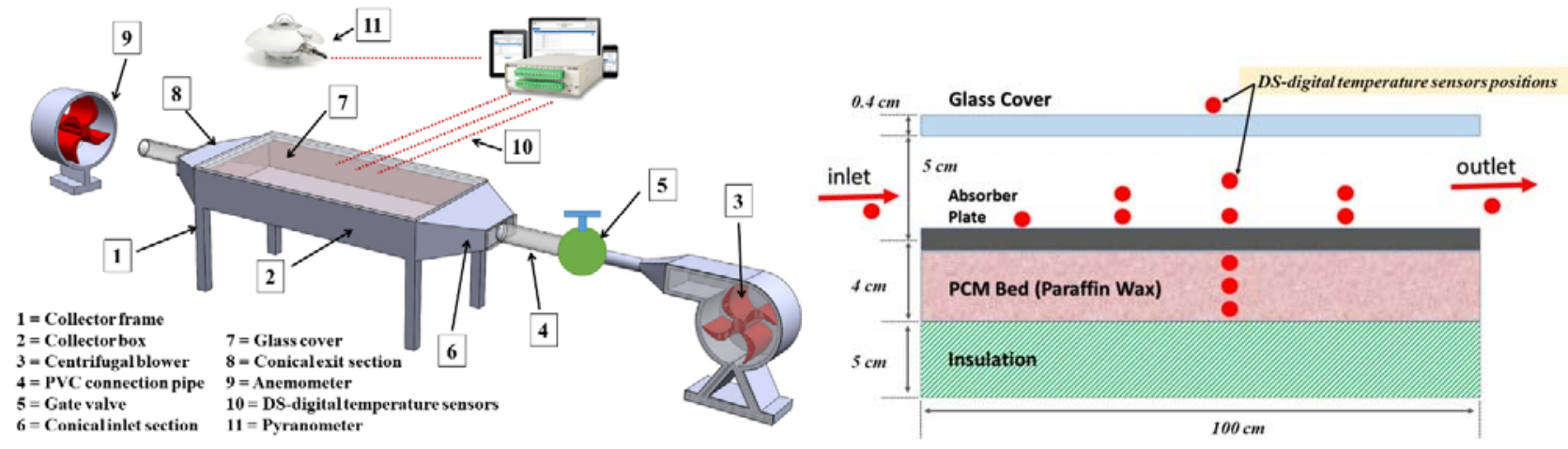

Figure 16 Schematic diagram of the tested experimental set-up of the solar air heater and its cross sectional view [128].

Moradi et al. [129] worked on optimizing a solar air heater using PCM through both approaches: experiments and simulations. The design of the double-glazed solar air heater utilized Paraffin based PCM that was placed underneath the absorber. Later on, the designed system was modeled using ANSYS Fluent 17 for optimizing the PCM thermal conductivity, PCM amount and the air mass flow rate in order to achieve high thermal energy efficiency and maximum nocturnal temperature difference between SAH's inlet and outlet. Results revealed that the average nocturnal temperature difference was kept at $4.5{ }^{\circ} \mathrm{C}$ using a layer with $4 \mathrm{~cm}$ thickness of paraffin under the absorber plate, equivalent to $23.5 \mathrm{~kg}$, and the total energy efficiency reached $37 \%$ at $65 \mathrm{~kg} / \mathrm{h}$ airflow rate. Abuska et al. [130] prepared three identical solar air heaters with single glazing to test the effect of PCMTES on the thermal performance and to investigate the effect of integrating honeycomb internal fin construction in the SAH (see Figure 17). Type I SAH contained a honeycomb core with PCM, type II contained only PCM, and type III had a flat absorber with no PCM as a reference for the study. Results showed that PCM heaters had an improvement of 2.6 to $22.3 \%$ in the daily thermal efficiency especially at high mass flow rates. Also, it was proved that the honeycomb core decreases the charging and discharging durations. Wadhawan et al. [131] analyzed the effect of integrating lauric acid as a PCM in a solar water heater. The results were promising showing an enhancement in the temperature of air leaving the SAH when the TES was used. 


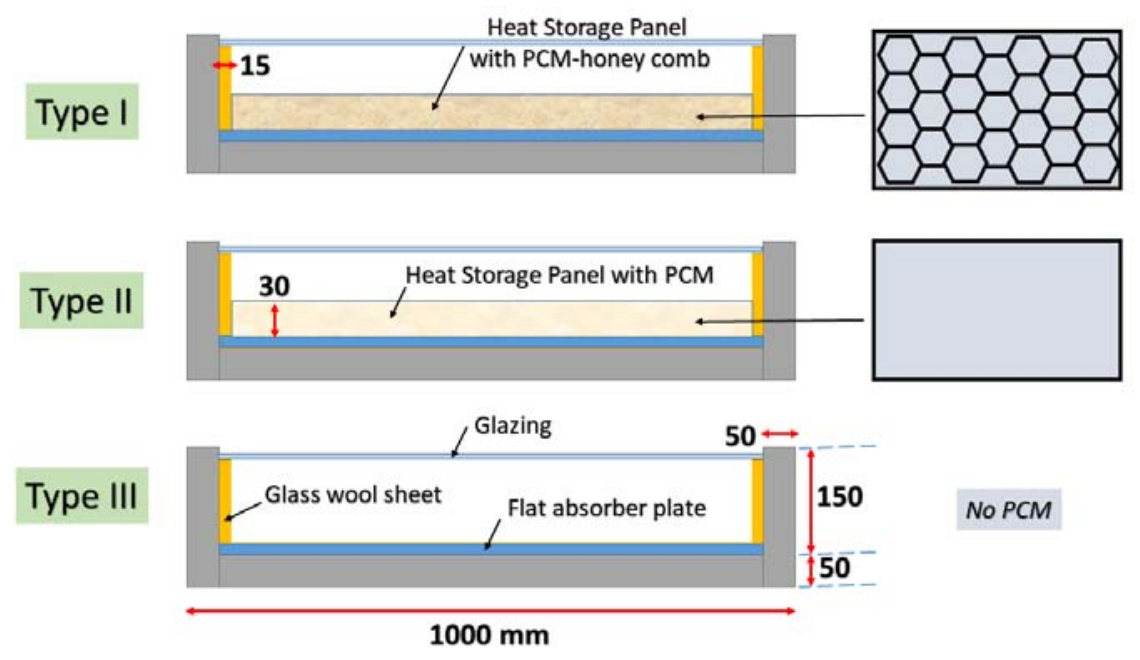

Figure 17 Cross-sectional schematic for the three types of the tested solar air heaters [130].

\subsubsection{Ventilated façades}

Gracia et al. [132] performed experimental investigation for a double skin ventilated solar façade integrated with 112 PCM panels distributed to form 14 air way channels. The mechanism is shown in Figure 18. Results revealed that the building thermal performance is increased, and a better enhancement can be obtained if thermal control system is integrated. The authors then in a later study [133] validated a numerical model, based on finite volume control approach, in attempt to create an operational schedule for melting and freezing process of the PCM. In the same field of study, Gracia et al. [118] tested the thermal improvement of the ventilated solar façade achieved by activating installed fans to meet the desired set study targets: controlled temperature and demand profile experiments. Experimental outcomes of measured electrical energy consumption of the heat pumps and fans proved that the use of mechanical ventilation in this system is unnecessary unless a fast heating supply is needed. Using the Gambit software for mesh generation and Fluent 6.3 for 2D CFD simulation, Diarce et al. [211] conducted a comparative study for a CFD model of a ventilated active façade. Results showed that the simulations are accurate and the model can be used for the investigation of active facades with and without PCMs under complete turbulence conditions. However, the authors recommend more research on the accuracy of the model for low turbulence conditions.

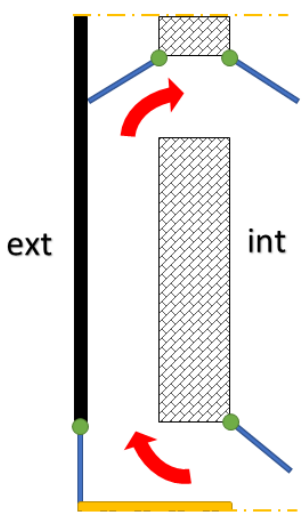

A

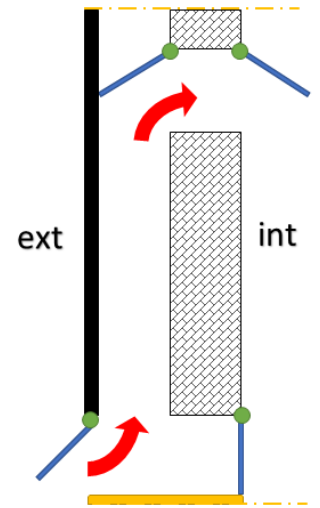

B

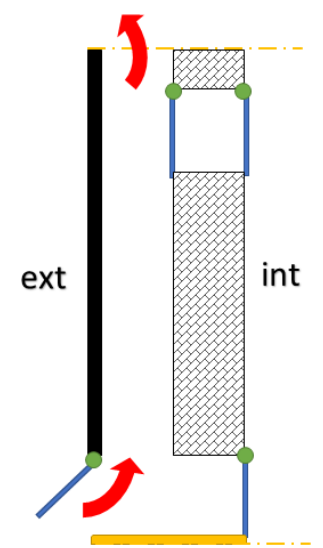

C

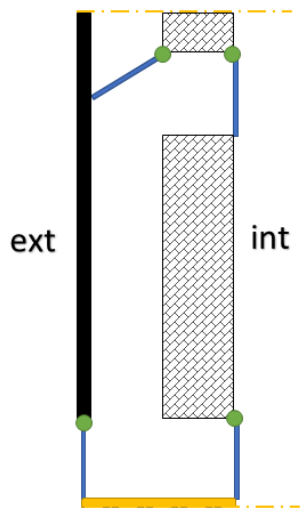

D

Figure 18 Principle of the Solar façade designed by Gracia et al. [132]. 


\subsubsection{Other active applications}

Sun et al. [134] designed a novel flat-heat pipe system for radiant heating purposes. The system utilizes inorganic PCM and a thermoelectric unit. The experimental investigation executed within the study showed that the PCM was able to sustain a heating temperature of $40^{\circ} \mathrm{C}$ for 42 minutes. Also, it was found that the COP of the thermoelectric unit was 1.7 when it functioned as an auxiliary unit. Youssef et al. [135] performed a novel experimental study to control an indirect solar assisted heat pump (IDX-SAHP) system integrated with a latent heat storage (PCM) tank. The special design of the PCM heat exchanger tank allowed an automatic control that permitted storing excess energy during day and releasing it upon request. Results showed that the PCM tank has a significant effect on the system operation stability and a respective improvement in the COP of $6.1 \%$ and $14 \%$ on sunny and cloudy days has been achieved compared to the system lacking the PCM. Plytaria et al. [136] used TRNSYS software to investigate the effect of integrating Q29-M91 Bio-based PCM panels with a solar assisted heat pump underfloor heating system for a $100 \mathrm{~m}^{2}$ floor plan building. The study evaluated the performance of three different types of solar collectors that are connected to a storage tank for winter heating purposes. It was found that: (1) Integrating a PCM layer with the underfloor heating system accounts for a $40 \%$ reduction in heating load; (2) A reduction of $42 \%$ to $67 \%$ in electricity consumption was achieved using the solar-driven systems; (3) The lowest grid electricity consumption was attained by adapting the thermal PV in the system.

Domestic hot water applications utilizing PCM is a promising technique. Aiming to perform off-peak auxiliary power shaving and to work under power outage, Deng et al. [137] performed an assessment and improvement of a solar domestic hot water system with PCM in its mantle. It was realized that $70.7 \%$ of the PCM heat storage was donated to the water in the tank. Also, according to the assessment of 16 test cycles lasting for more than 3 months, no performance degradation occurred for the PCM composite implying that it is stable, indicating that the PCM heat storage worked well as a thermal battery and would be a potential for promotion in domestic heat storage of dwellings in the low-temperature solar thermal market. In order to increase the amount of the stored energy in a limited portion of time during maximum solar radiation, Gorzin et al. [138] studied the possibility of reducing the melting time of the PCM used in a heat exchanger placed in a flat solar heater plate utilizing water as the heat transfer fluid. In order to find the best PCM distribution between inner and outer annulus of the proposed multi-tube heat exchanger, the authors studied the charging process of RT-50 as the PCM on a shell and multi-PCM-tube by heated water from flat plate solar collector. The results show that by distributing the PCM mass in which $40 \%$ of PCM mass is in inner tube and $60 \%$ in the circumferential annulus, a reduction in melting time reached $52 \%$, emphasizing that solar energy can be used more efficiently in the time of maximum solar radiation.

Iten et al. [139] performed an experimental test on the behavior RT25 PCM filled in metallic plates and placed in an air heater unit serving as a TES unit. The results were used for direct comparison with the simulations obtained using ANSYS Fluent 15.0 software using two CFD methods: Effective heat capacity method and Enthalpy method. It was revealed that Enthalpy method is suitable for predicting PCM temperature for pure PCMs and not for commercial composites, where the effective heat capacity method proved to be more efficient. However, both methods showed efficient predictions in the case of air outlet temperature simulations. M. Fadl and Eames [140] prepared a multi-pass tube heat exchanger oriented vertically adopted to a PCM container filled with RT44HC, used for domestic hot water in buildings. The study aimed to analyze the experimental results related to the variation of the heat transfer fluid (HTF) inlet temperature and its effect on charging/discharging rates of PCM. It was shown that an increase of $10^{\circ} \mathrm{C}$ for the HTF inlet temperature led to a decrease of $3.5 \mathrm{hrs}$ in charging time.

\section{Use of PCM-TES for Hybrid applications in Buildings}

Thermal energy storage in buildings is necessary to present a balance between the energy demand and availability annually during both heating and cooling seasons [44]. For that, a good TES system is that working 
in several seasons and weather conditions. Hybrid applications for buildings are that which involves overheating reduction during summer, and heat storage during winter.

\subsection{Hybrid passive methods}

Most popular passive method is the integration of PCM in building envelope including walls, wallboards, plastering mortar bricks, as well as windows, roofs and floors.

Sun et al. [141] executed experimental tests on lightweight buildings walls integrated with PCM spherical capsules to investigate their optimal position. The tested walls were three: Wall A composed of five XPS insulation layers, Wall B composed of 4 XPS layers and a cavity-integrated sheet, and Wall C composed of 4 XPS layers with PCM integrated sheet. It was proved by the authors that for summer and annual cases, the third layer is the optimum position for PCM spheres, while concerning winter case it is best to have the PCM spheres in the fourth layer.

Saafi and Daouas [142] performed a numerical study, using Energy Plus, on the effect of integrating PCM into building envelopes within the Mediterranean climate of Tunisia. Results showed that integrating PCM on the outside face of a brick wall contributed to an energy saving of $13.4 \%$ for south orientation. Within their study on using PCMs for limiting the temperature swings of high-rise buildings with high window to wall ratios, Berardi and Soudian [143] performed an experimental test compromising composite PCMs with $21.7^{\circ} \mathrm{C}$ and $25^{\circ} \mathrm{C}$ melting temperatures. The adaptation of the composite PCMs in the walls and ceiling of the test cell, with $80 \%$ window to wall ratio, revealed a decrease of $6^{\circ} \mathrm{C}$ in the peak indoor and surface temperatures.

Pisello et al. [144] worked on an innovative multifunctional concrete incorporating 5\% paraffin-based microcapsulated PCM compared to normal concrete of the same thickness. Authors conducted a new experimental technique to investigate the dynamic thermal performance of the PCM-doped concrete walls by measuring the thermal diffusivity, thermal conductivity, and volumetric specific heat using CC-TPS method to bridge the gap between in-lab PCM investigation and the expensive full-scale prototype experimentations. Particularly, the setup of the technique couples the usage of the HOT DISK TPS 2500S unit and the ATT DM 340 SR climatic chamber (see Figure 19). Obtained graphs show that thermal conductivity and thermal diffusivity decrease with time during phase change, while volumetric specific heat increase. On the other hand, it was shown that due to the sub-cooling phenomena of the bio-based PCM there is a difference in the thermal behavior of the PCM during crystallization and melting. Boussaba et al. [29] prepared an eco-friendly and low-cost bio-based PCM using coconut fat recovered from underused feedstocks. The study aimed to fabricate a novel composite PCM for improving thermal inertia of building envelopes. Using the direct immersion method, the authors prepared a composite PCM from natural clay, cellulose fibers, graphite and coconut fat. Thermal treatment, DSC, FT-IR, SEM, TGA and thermal conductivity analysis were performed on the tested module. The results were promising in terms of enhancing thermal inertia by which the material was proved to be: Chemically stable, uniformly distributed in its matrix, thermally stable, has promising thermal properties, and of enhanced thermal conductivity. At the end the prepared composite PCM was formed as a sandwich panel between two stainless steel sheets of $1 \mathrm{~mm}$ thickness for direct integration with building envelopes in an attempt for its commercialization.

Using type 204 in TRNSYS 17 software, Derradji et al. [145] completed a thermal dynamic simulation for two top floor offices in Algeria: one with conventional walls and the other with walls incorporating PCM. The modeled office contained a double-glazing window and only the southern wall was in contact with the outdoor. Results showed that an enhancement in thermal environment was attained where the use of the PCM contributed to an increase in the indoor temperature in winter by $4^{\circ} \mathrm{C}$, and a decrease by $7^{\circ} \mathrm{C}$ in summer, compared to the conventional office. This lead to an overall of $25 \%$ energy savings for heating and cooling in Algeria climate. 
A

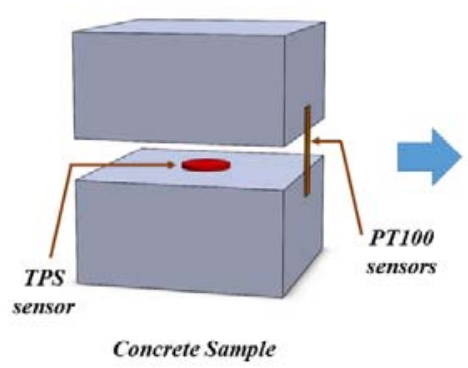

B

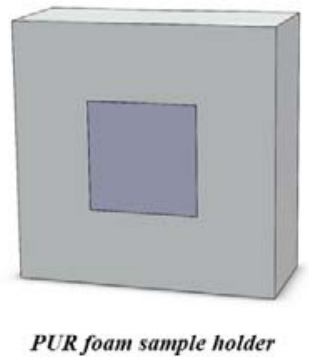

C

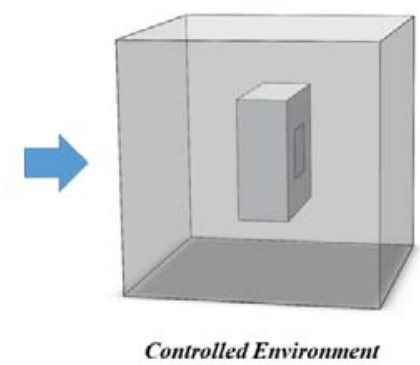

Figure 19 Experimental setup: (a) concrete samples and TPS sensor positioning, (b) polyurethane guard setup and concrete samples positioning, and (c) final experimental setup in the environmental climatic chamber [144].

Souayfane et al. [146] analyzed the energetic and economic performances of a novel PCM wall utilizing a transparent insulation material. Results showed that incorporating the TIM-PCM wall, compared to double-glazed wall, has higher efficiency within the studied climates, for the case of south oriented wall. The authors emphasized on the importance of climatic conditions, energy costs, energy savings, the discount rate in the country and the costs of the system investment while studying the economic viability of TIM-PCM wall application. Hanchi et al. [147] conducted a numerical study on the thermal behavior of a dynamic regime for a multilayer roof with two PCM layers of different melting points. The study focuses on comparing two conditioned zones in Casablanca and Ouarzazate, Morocco with two different comfort temperatures $\left(18^{\circ} \mathrm{C}\right.$ and $\left.20^{\circ} \mathrm{C}\right)$ for the cases of a reference conventional roof and another roof with integrated PCM as shown in Figure 20. Six different PCMs were used in 18 combinations with melting temperatures ranging between $19^{\circ} \mathrm{C}$ and $34^{\circ} \mathrm{C}$. With the 7 assumptions made, it was found that the relative deviation of energy consumed $(\sigma)$ is always lower than zero indicating that the insertion of PCM is always beneficial. Moreover, reduction of annual consumption presented by $\sigma$ is high for PCM combinations having a low $\mathrm{Tm}$ that is slightly higher than the occupied zone comfort temperature for the first PCM layer (i.e. $21^{\circ} \mathrm{C}$ and $23^{\circ} \mathrm{C}$ for comfort temperature of $20^{\circ} \mathrm{C}$; and $19^{\circ} \mathrm{C}$ and $21{ }^{\circ} \mathrm{C}$ for the case of $18^{\circ} \mathrm{C}$ ), and a relatively higher Tm for the second PCM.
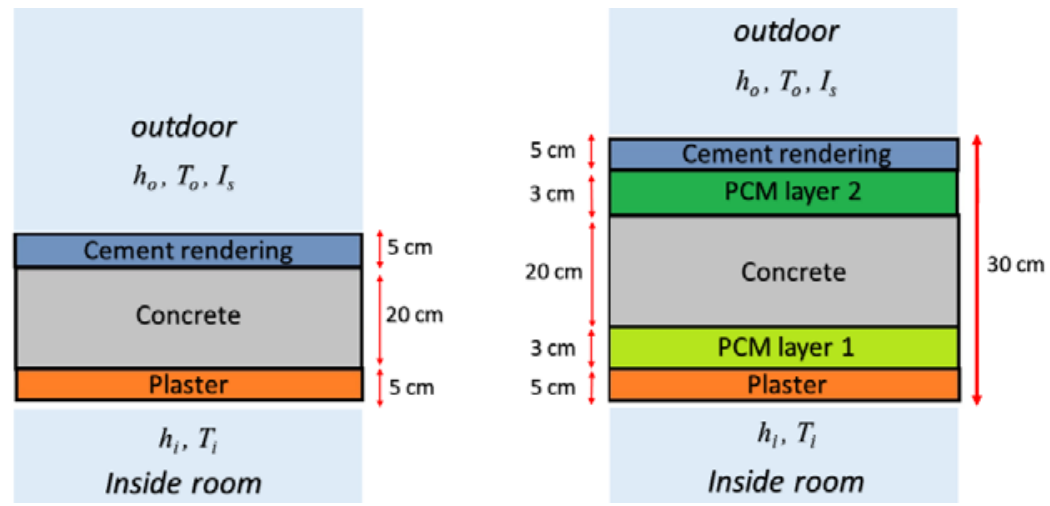

Figure 20 Illustrations of the (a) reference roof and (b) the roof with the two integrated PCM layers [147].

Yang et al. [148] investigated the thermal behavior of a novel plastering mortar incorporating three PCM layers. The comparison between conventional mortar and the hybrid mortar studied reflects the potential of PCM to reduce heating/cooling loads and maintain thermal comfort.

A numerical thermal analysis utilizing CFD model prepared through the incorporation of PCM in steel capsules at the middle of a brick with cylindrical air cavities for thermal insulation enhancement was conducted by Dabiri et al. [149]. The aim was to test a brick containing PCM and investigate the PCM role in improving thermal comfort. It was proved that at the coldest day in Tehran, Iran, the temperature contours inside the room remained at near thermal comfort as the external temperature changed with time. Final results ensured that thermal 
regulation was achieved by PCM bricks during winter and summer however heat storage was mostly sensible in winter and latent in summer. Marin et al. [150] evaluated the performance of a relocatable lightweight building incorporating PCM wallboards and monitored the effect of PCM on energy savings. The obtained results highlighted the potential of PCM in reducing energy consumption throughout the year in Chilean climates. However, for extreme cold and extreme hot climates, the effect of such passive TES system is limited. It was recommended to optimize the melting temperature of the PCM intended to be used for each climate in order to maximize its potential.

The dynamic thermal performance of a four-pane glazing window containing macro-encapsulated salt-hydrate PCM in its internal cavity was investigated by Grynning et al. [151]. The system was installed in a large scale test hut located in a large scale climate simulator in Switzerland, and utilized a prismatic glass at the exterior cavity for transmittance control. And, it was compared to a conventional double pane window commercially present in the country. Results showed that PCM window is capable of improving thermal comfort, however for full activation of PCM, high outdoor temperature and radiations are required.

Due to high costs for experimental investment, it is of great need to improve reduced-scale experiments in order to obtain methods for investigating thermal performance of PCM applications so that less material, time, and volume are required. Young et al. [152] performed an experimental study on a reduced-scale prototype containing PCM in its wall, placed in a climatic chamber. The study was then extended to numerical investigation for the performance of full-scale buildings.

Vanaga et al. [18] performed a small-scale experiment on a developed solar façade module (Figure 21) comprising a combination of RT21HC PCM, granulated aerogel for heat losses reduction, Fresnel lens and copper plate with 25 cylindrical pins as heat transfer enhancers, and a reference box with neither lens, enhancer nor PCM. Experiments showed that the dynamic behavior of the solar façade module showed a 4 times higher heat flux due to solar radiation concentrated by the lens, compared to the reference room. Then, after good agreement with simulated results on COMSOL, the authors performed 4 daily simulations covering summer, winter, late and early autumn; for (A1) solar façade module, and (A2) module with opaque wall. Results showed that the indoor temperature difference ranges between $0.5^{\circ} \mathrm{C}$ to $9^{\circ} \mathrm{C}$ between $\mathrm{A} 1$ and $\mathrm{A} 2$. Both simulations and experimental results indicate that the use of Fresnel lens for solar radiation concentration combined with insulation materials and PCM, can increase the indoor temperature and reduce building energy consumption for heating in cold climates compared to opaque wall, however it caused overheating in hot weather conditions. 


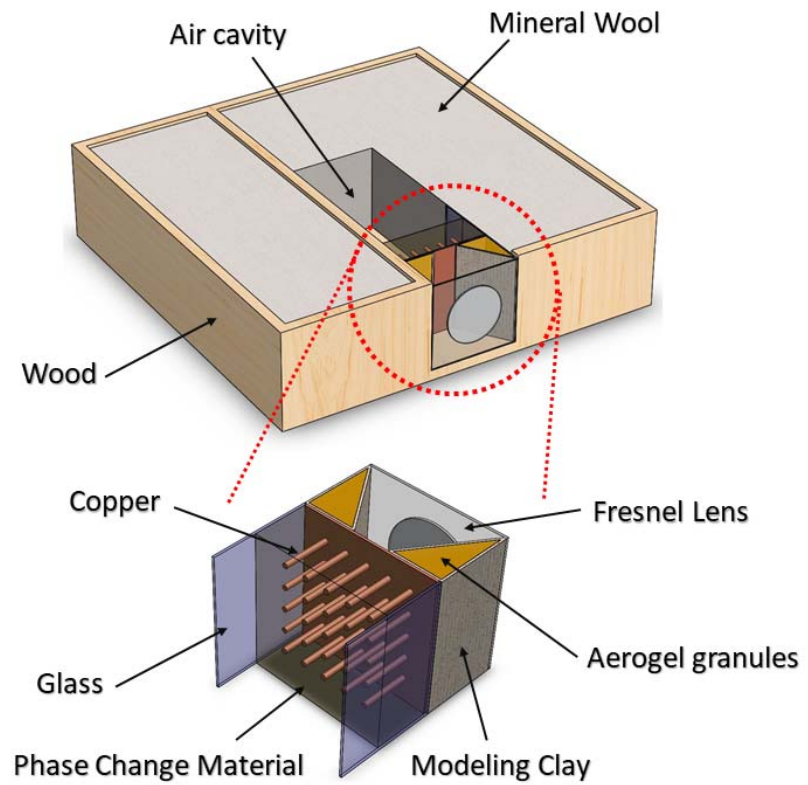

(a)

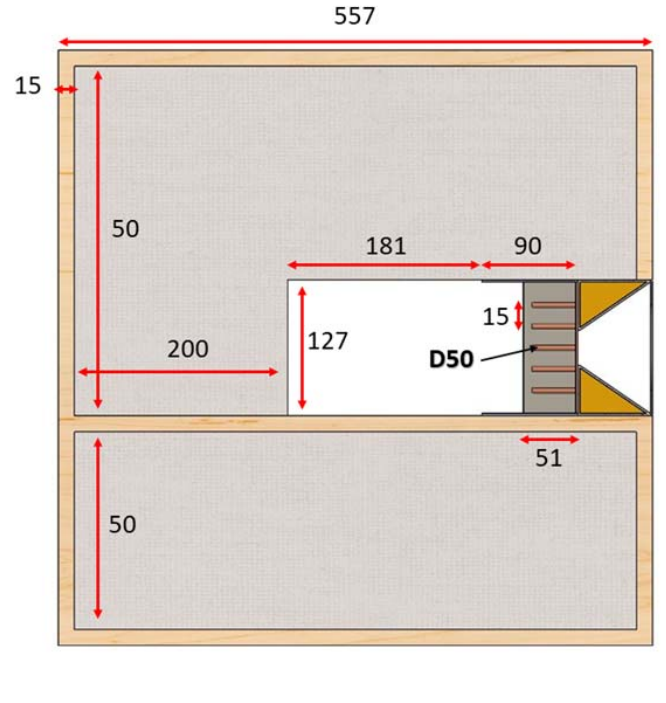

(b)

Figure 21 Graphical views of (a) Experimental test boxes of the solar façade module and the reference one, with (b) a schematic diagram for the cross-section of the façade module [18].

$\mathrm{Li}$ et al. [153] investigated the thermal behavior of glazed windows filled with nano-PCM in different seasons. The numerical model was validated with the experimental results obtained. The authors proved that a temperature difference between interior surface of glazed windows and indoor environment are in the range of 1-4 in summer, 5-10 in autumn, 14-16 in winter. Nevertheless, energy consumption can be reduced by $4 \%$ only corresponding to the suitable selection of the Nanoparticles sizes.

Guldentops and Dessel [154] performed an experimental test on a cellular passive solar façade designed such that small air cells are backed with PCM in order to thermally condition the building (see Figure 22). The authors then conducted a numerical simulation for the proposed model and validated it with experimental results. It was shown that an increase in the system efficiency was obtained upon the addition of PCM behind the air cell in both hot and cold seasons. Besides, during summer, up to $42 \%$ reduction in heat gains using PCM. 


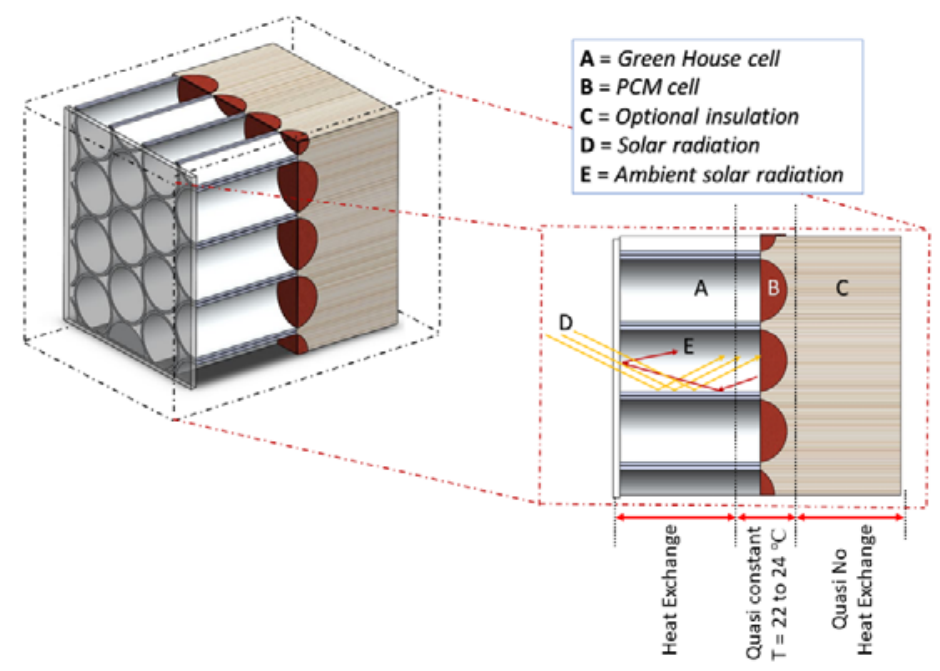

Figure 22 The proposed design of the cellular solar façade [154].

All what have been reviewed was utilizing PCM in heating and passive hybrid applications by incorporating the PCM with one of the five major incorporation methods: direct mixing, imbibing, shape-stabilization, macroencapsulation and microencapsulation. However, a new evolving technology for PCM envolvement in building applications is the adaptation of PCM as nanoparticles in textiles, fibers, fabrics and foams. Sarter and Onder [155] prepared a massive overview on the evolving technology of Organic nano-PCM and its applications in clothing and textiles, particularly their integration in fibers, fabrics and foams using direct impregnation and microencapsulation techniques.

\subsection{Hybrid active methods}

Stritih et al. [156] tested the thermal performance of a solar air heater utilizing a LHTES unit containing PCM plates (Figure 23) in the weather condition of Ljubljana, Slovenia. The authors also performed numerical simulations for the tested facility using TRNSYS. Annual cost savings of 58\% for the system without PCM compared with $68 \%$ for the system with PCM, if the running costs were only considered. However, if the investment costs were taken into consideration, compared to district heating, annual savings will reach $91 \%$ and 93\% for PCM system and reference one respectively. Osterman et al. [157] proposed an office solar air heater incorporating 15 or 30 RT22HC paraffin based PCM plates (depends on the case study) as TES system (Figure 24). Using Fluent simulator, results showed that there is a good agreement between simulations and experimental values. March in winter, July and August in summer represent the months where largest savings by PCM unit are obtained. Besides, for a typical office building it was revealed that up to $142 \mathrm{kWh}$ decreased in energy consumption can be achieved.

HVAC systems are dedicated to provide thermal comfort to occupants all seasons. Thus, the integration of TES systems is best adapted if they contribute to energy efficiency increase during cooling and heating seasons. Maccarini et al. [158] performed a numerical analysis for evaluating the performance of a PCM-based heat exchanger coupled with a novel HVAC system for simultaneous heating and cooling of buildings. Results inferred that for a typical office building, the integrated free cooling devices, of which is the PCM-TES, are capable of reducing the primary energy use of the novel HVAC system, with energy savings by the PCM-TES system of about $67 \%$ when compared to the base-line thermal plant configuration. Another study by Said and Hassan [159] focused on testing the effectiveness of several PCMs adapted to the air conditioning unit condenser and its effect on the coefficient of performance of the unit.

Wu et al. [160] applied an experimental study on the performance of a novel solar water heater incorporating PCM. The system showed favorable results on annual basis under different seasons (Figure 25). At summer time, the SWH with PCM was able to keep the exit water temperature during night above $50^{\circ} \mathrm{C}$ which is decreased in case of the system without PCM. It was also observed that in winter nights, the coefficient of performance of the 
SWH with PCM is over 3 which can make the exit water temperature reach $50^{\circ} \mathrm{C}$ in much shorter time than the reference system without PCM.

In their study on enhancing AC systems, Behi et al. [161] assessed the performance of a novel solar assisted sorption modules (SM) for both heating and cooling purposes. The systems utilized RT11 PCM for cooling, and RT27 for heating. Results showed that for the $\mathrm{LiCl}-\mathrm{H}_{2} \mathrm{O}$ based SM, the average values of COP for heating and cooling are 0.42 and 0.36 , respectively. Ansuini et al. [162] performed an experimental study on a radiant floor integrated with PCM for indoor temperature control. The study included a simulation of a 2D model for the examined system to cover all weather conditions. It was shown that during summer conditions, for a $16 \mathrm{~m}^{2}$ room, radiant cooling by PCM floor allowed a saving of approximately $25 \%$ of the water used for cooling. However, PCM was able to buffer the direct radiant gains of the sun and in general the internal gains, during mid-season. Thus, an improvement was depicted for the integration of the floor into systems using intermittent renewable energy sources. However, in the conditions of winter no effect on the heating behavior was monitored with the optimized PCM layer.

One of the hybrid active methods is the adaptation of PCM incorporated with air ventilation tubes to couple the purposes of intra-ventilation and enhanced envelope thermal inertia. This study was performed by Laaouatni et al. [163] using two validated simulation methods. Results proved the effectiveness of such system in diminishing the problem of anti-symmetry storing/recovering of the PCM to function annually covering hot and cold climates.

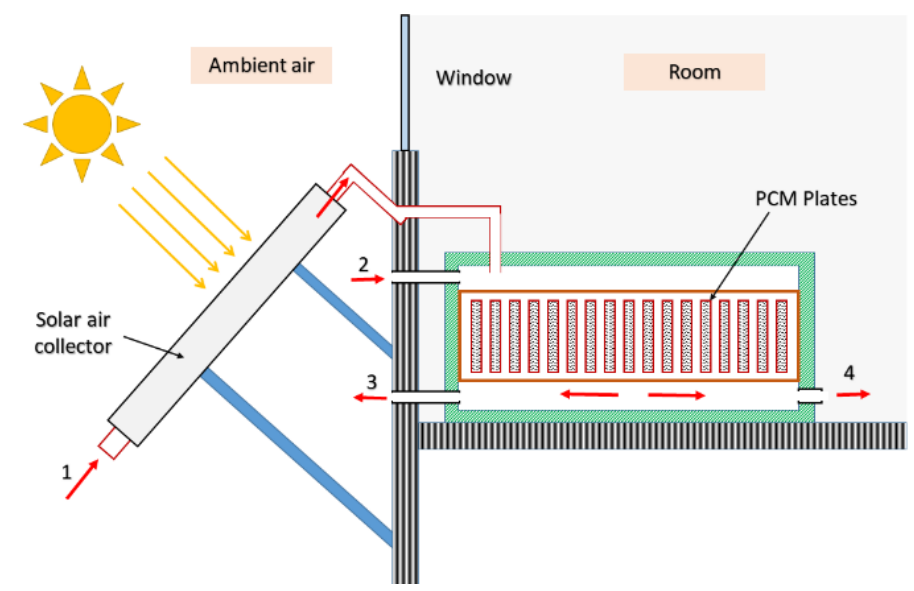

Figure 23 Schematic diagram showing the solar air heater unit design [156].

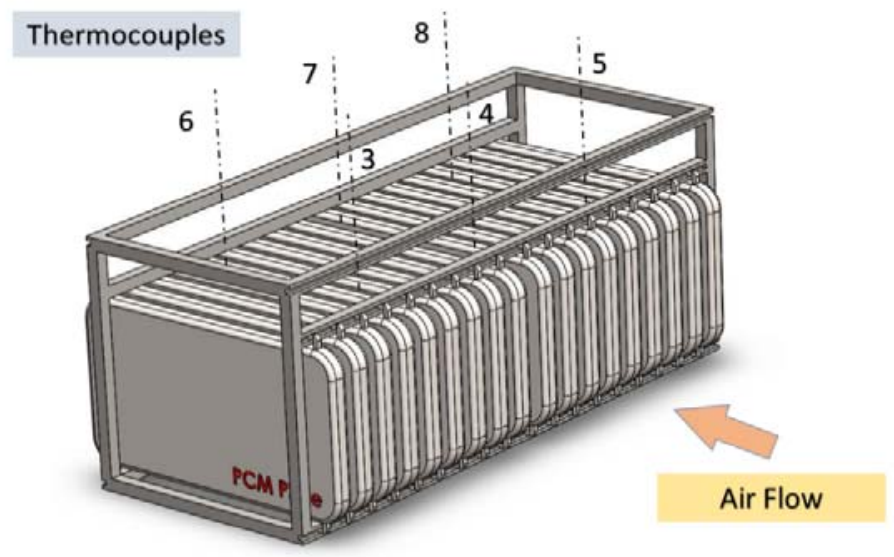

Figure 24 Schematic for the TES unit placed in the office [157]. 


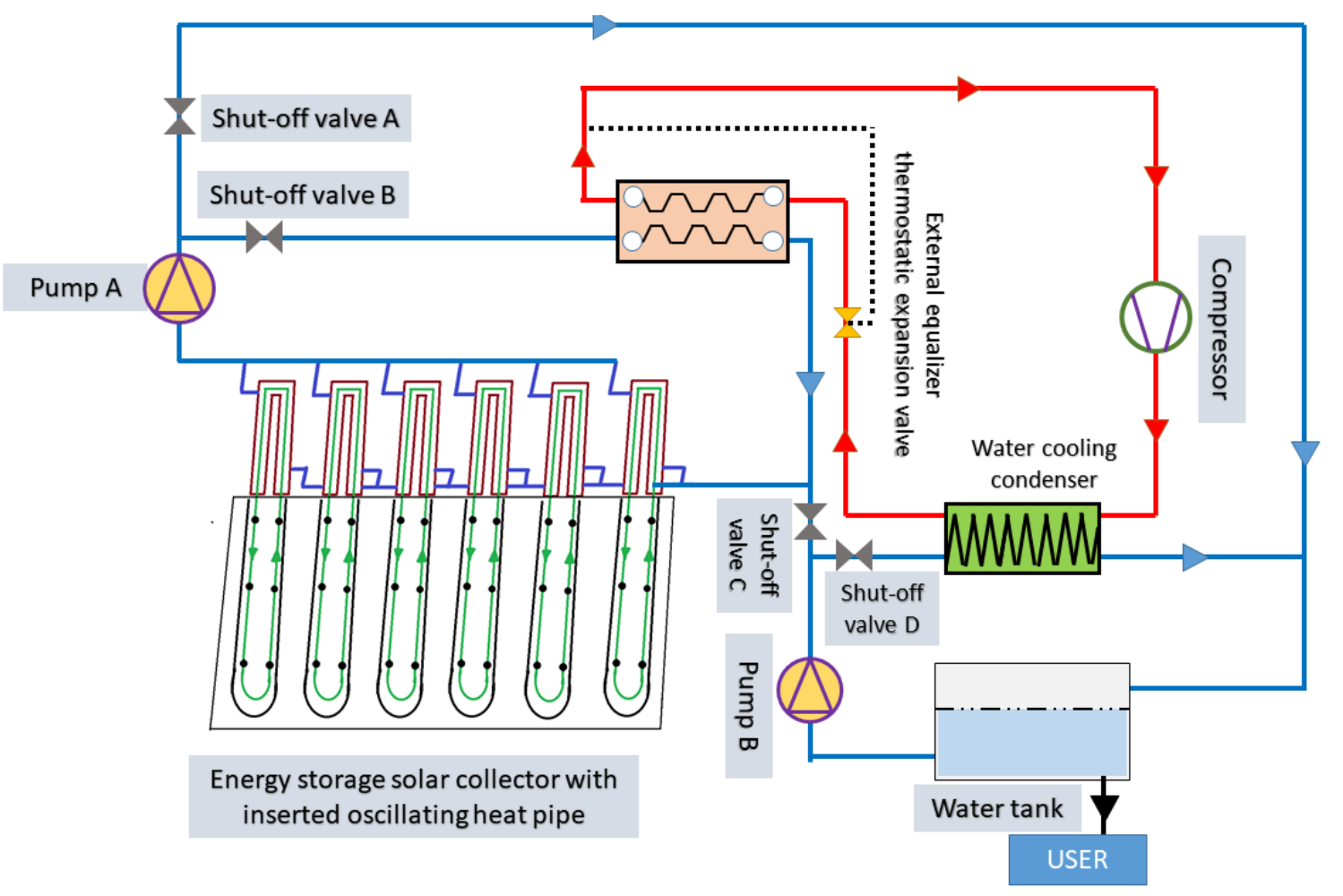

Figure 25 The schematic diagram of the Novel Solar water heater utilizing PCM [160].

Finally, to summarize all reviewed applications for the systems that are classified as active or passive, a schematic diagram showing the classification of the applications for heating and hybrid systems utilizing PCMs in buildings are illustrated in Figure 26. Then, a summary for the literature on the use of phase change materials in buildings for heating and hybrid applications are summarized in Table 3. Also, the used PCM types, thermos-physical properties, incorporation methods and applications are summarized in Table 4. 


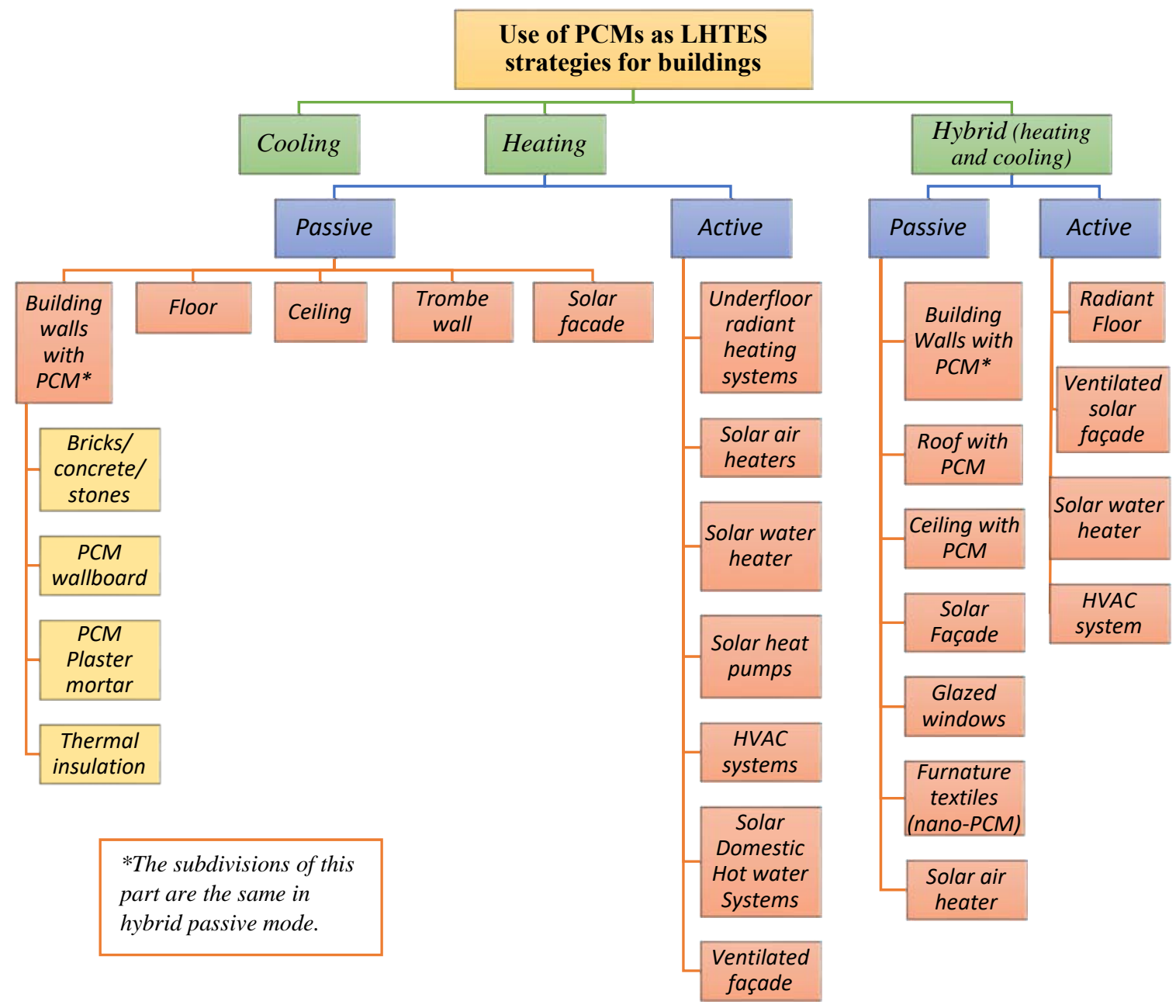

Figure 26 Schematic diagram for heating and hybrid applications of PCM-TES in buildings as discussed in the current review article. 
Table 3 Summary of literature for PCM heating and hybrid applications for buildings.

\begin{tabular}{|c|c|c|c|c|c|c|c|}
\hline $\begin{array}{c}\text { Test } \\
\text { methodology }\end{array}$ & Prototype/software & Climate & Used PCM & Application & $\begin{array}{l}\text { PCM-LHTES } \\
\text { technique/system }\end{array}$ & Key results & Ref. \\
\hline Numerical & TRNSYS 17 & Algeria & - & $\begin{array}{l}\text { Heating and } \\
\text { cooling }\end{array}$ & $\begin{array}{l}\text { PCM in concrete } \\
\text { ceiling and hollow } \\
\text { brick walls }\end{array}$ & $\begin{array}{l}\text { - Increase of office temperature by } 3-4^{\circ} \mathrm{C} \text { in winter. } \\
\text { - Decrease of office temperature by } 7{ }^{\circ} \mathrm{C} \text { in summer. }\end{array}$ & {$[145]$} \\
\hline Numerical & - & $\begin{array}{l}\text { Casablanca and } \\
\text { Ouarzazate, } \\
\text { Morocco }\end{array}$ & $\begin{array}{l}18 \text { eutectic } \\
\text { combinations of } 6 \\
\text { PCMs }\end{array}$ & $\begin{array}{l}\text { Heating and } \\
\text { cooling }\end{array}$ & $\begin{array}{l}\text { Multilayer of PCM } \\
\text { in roof }\end{array}$ & $\begin{array}{l}\text { - Reduction in annual consumption increases for } \\
\text { cold period PCM of Tm slightly higher than comfort } \\
\mathrm{T} \text { and the second PCM with relatively higher Tm. }\end{array}$ & {$[147]$} \\
\hline Experimental & $\begin{array}{l}\text { Two } 10 \times 10 \times 5 \\
\mathrm{~cm}^{3} \text { rectangular } \\
\text { concrete prisms }\end{array}$ & - & $\begin{array}{l}\text { Paraffin based } \\
\text { micro-capsulated } \\
\text { PCM }\end{array}$ & $\begin{array}{l}\text { Heating and } \\
\text { cooling }\end{array}$ & $\begin{array}{l}\text { PCM doped } \\
\text { concrete wall }\end{array}$ & $\begin{array}{l}\text { - The new proposed methodology is validated for } \\
\text { measurements of thermal conductivity, diffusivity } \\
\text { and volumetric specific heat. }\end{array}$ & [144] \\
\hline Experimental & $3 \mathrm{~m}$ side cubicle & $\begin{array}{l}\text { Casablanca, } \\
\text { Morocco }\end{array}$ & $\begin{array}{l}\text { Paraffin based } \\
\text { PCM }\end{array}$ & Heating & $\begin{array}{l}\text { PCM incorporated } \\
\text { to internal faces of } \\
\text { tested cubicle (walls } \\
\text { and ceiling) }\end{array}$ & $\begin{array}{l}-50 \% \text { thermal loss reduction in ceiling } \\
-20 \% \text { overall energy. consumption reduction. } \\
\text { - } 6 \mathrm{~h} \text { time shift between entering and leaving flux } \\
\text { densities through PCM. }\end{array}$ & [89] \\
\hline $\begin{array}{l}\text { Experimental } \\
\text { and Numerical }\end{array}$ & $\begin{array}{l}\text { Two identical huts } \\
(2.63 \times 2.64 \times \\
\left.2.64 \mathrm{~m}^{3}\right) / \\
\text { EnergyPlus }^{\circledR} \\
\text { software }\end{array}$ & $\begin{array}{l}\text { Auckland, New } \\
\text { Zealand }\end{array}$ & $\begin{array}{l}\text { Paraffin-based } \\
\text { PCM }\end{array}$ & Heating & $\begin{array}{c}\text { High } \mathrm{T}_{\mathrm{m}} \text { PCM } \\
\text { impregnated in } \\
\text { underfloor Gypsum } \\
\text { board and low } \mathrm{T}_{\mathrm{m}} \\
\text { PCM DuPont sheets } \\
\left(\text { Energain }{ }^{\circledR} \text { ) lined in }\right. \\
\text { walls and ceiling }^{\text {(Ened }}\end{array}$ & $\begin{array}{l}\text { - load shifting is limited at the morning and } \\
\text { profitable at evening. } \\
\text { - cost saving of } 42 \% \text { corresponding to an energy } \\
\text { saving of } 32 \% \text {. }\end{array}$ & {$[17]$} \\
\hline $\begin{array}{l}\text { Experimental } \\
\text { and Numerical }\end{array}$ & $\begin{array}{l}\text { Two test boxes } \\
\text { with and without } \\
\text { façade module / } \\
\text { COMSOL } \\
\text { Multiphysics } 5.1\end{array}$ & Latvia & RT21HC & $\begin{array}{l}\text { Heating and } \\
\text { Cooling }\end{array}$ & $\begin{array}{l}\text { Solar façade module } \\
\text { with PCM }\end{array}$ & $\begin{array}{l}\text { - Fresnel lens with PCM and insulation can increase } \\
\text { the indoor temperature and reduce building energy } \\
\text { consumption for heating in cold climates. }\end{array}$ & [18] \\
\hline Experimental & $\begin{array}{l}\text { Two identical huts } \\
(2.62 \times 2.62 \times \\
\left.2.64 \mathrm{~m}^{3}\right)\end{array}$ & $\begin{array}{l}\text { Tamaki, } \\
\text { Auckland, New } \\
\text { Zealand }\end{array}$ & $\begin{array}{l}\text { Paraffin-based } \\
\text { PCM }\end{array}$ & Heating & $\begin{array}{l}\text { PCM underfloor } \\
\text { heating with PCM } \\
\text { wallboards }\end{array}$ & $\begin{array}{l}\text { - cost saving of } 18.8 \% \text { during } 5 \text { days }(35 \% \max ) \\
\text { - energy saving of } 28.7 \% \text { during } 5 \text { days }(44.4 \% \max )\end{array}$ & [123] \\
\hline Experimental & $\begin{array}{l}\text { Test facility }(2.6 \times \\
\left.2.1 \times 2 \mathrm{~m}^{3}\right) \text { with } \\
\text { window and door }\end{array}$ & $\begin{array}{c}\text { Basemen of an } \\
\text { office, Beijing, } \\
\text { China }\end{array}$ & $\begin{array}{l}\text { In-organic macro- } \\
\text { encapsulated }\end{array}$ & Heating & $\begin{array}{c}\text { Radiant floor } \\
\text { heating with macro- } \\
\text { encapsulated PCM } \\
\text { bags }\end{array}$ & $\begin{array}{l}\text { - capillary mat is more efficient than PE coils in } \\
\text { providing thermal comfort } \\
\text { - PCM (latent) in floor attained twice longer } \\
\text { discharging time for keeping thermal comfort } \\
\text { compared to sand (sensible) }\end{array}$ & {$[121]$} \\
\hline
\end{tabular}


Two test rooms

$\left(4 \times 3 \times 3 \mathrm{~m}^{3}\right)$ in

$2^{\text {nd }}$ floor each with

a window covered

Anhui, Chin
(subtropical

with black curtain

climate)

ANSYS / second

floor room with

Experimental

and Numerical

$\mathrm{A}=11.02 \mathrm{~m}^{2}$

$\mathrm{h}=3 \mathrm{~m}$ )

Underflow V-

Experimental

corrugated Solar

air heater

TRNSYS / Solar

Experimental

and Numerical

air heater LHTES

Ljubljana,

Slovenia

Two floorplan

Experimental

rooms facing

Erzurum,

Turkey

Two sided

identical test

rooms $(3.5 \times 3 \times$

$\left.2,2 \mathrm{~m}^{3}\right)$

Experimental

EnergyPlus ${ }^{\circledR} /$

and Numerical

Three identical

lightweight huts

Chiba

Prefecture,

Japan

SSPCM sheets

Dymola

Modelica ${ }^{\circledR}$

affin-based

HCE-SSPCM

"Natural TCM

energy saver"

product

Numerical
Heating

Electric floor

heating with HCE-

SSPCM rectangular

plates

consumption compared to other heating systems

- more economic benefits and more cost-effective

performance achieved by HCE-SSPCM

Macro-encapsulated

within prefabricated

- PCM floor releases $47.7 \%$ of energy supplied by

concrete skeleton

Spherical macro-

capsules forming a

packed bed storage

tank

and discharging of and discharging of PCM is reached at $200 \mathrm{~kg} / \mathrm{h}$.

- maximum capacity of the storage system and

longer heating duration are attained with low mass flow rates.

29 compact storage

modules (CSM)

filled with paraffin

with an exterior

solar collector

Novel triple glass with PCM wall

Exterior wall

Heating

rated with $2 \mathrm{~cm}$

PCM layer

4 layers of $\mathrm{PCM}$

sheets in floor of B,

and one layer per

prismatic side in $\mathrm{C}$

Trombe-Michel

wall with PCM

layer
- Annual cost saving of $68 \%$ for the solar air heater with PCM compared to $58 \%$ for that without PCM if only operating costs are considered.

- Ratio of solar energy gain over by PCM walls to heat load varied between $4 \%$ and $70 \%$.

Higher inner surface temperature for PCM wall when heater was off.

- While heating, the inner heat flux was lower by

$18.48 \%$ in the PCM wall compared to reference.
Heating
- With the same amount of PCM in huts B and C, heat storage performance changed ensuring the importance of installation area and position.

- Large capacity of heat recovery was achieved by the PCM Trombe wall compared to concrete. 
FLUENT 15.0

air-PCM heat

Experimental

and Numerical

transfer unit with

heating coil and

exhaust fan

Three test facilities

Experimental $\quad\left(86 \times 96 \times 120 \mathrm{~cm}^{3}\right)$

and Numerical

with facades and

windows

Daqing, China

o identical test

$$
\text { facilities }
$$

Experimental

$\left(2.4 \times 2.4 \times 5.1 \mathrm{~m}^{3}\right)$

ANSYS Fluent 17

Experimental

and Numerical

/ Double-glazed

$\mathrm{SAH}$

Experimental

Single-glazed SAH

Bayar

University,

Turkey

Numerical

Experimental

and Numerical

\section{FLUENT / Single-} glazed SAH

Numerical

Fluent 6.3 and

Gambit 2.2

Spain

Marrakech,

Morocco

In-organic salthydrate

Lauric acid

RT35

Heating

Novel Solar Water

$$
\text { System }
$$

RT25

Heating
Air-PCM unit with

PCM panels

Effective heat capacity CFD method is

recommended for PCM thermal performance

analysis.

non-ventilated

multilayer glazing

facades with PCM

layer in the middle

- An increase in interior surface temperature and

temperature time lag when increasing PCM

thickness which enhances thermal comfort.

Ventilated façade with 112 PCM

panels, 14 air flow

- Improvement in building thermal behavior that needs thermal control for surplus enhancement. channels

Double-glazed solar - The optimum thickness of PCM is $4 \mathrm{~cm}(23.5 \mathrm{~kg}$ in air heater with PCM this SAH) that allowed a total thermal efficiency of

layer below the $\quad 37 \%$ and a temperature difference between inlet and absorber outlet of $4.5^{\circ} \mathrm{C}$

Single glazed solar air heater with

honeycomb core filled with PCM

- 2.6 to $22.3 \%$ improvement in daily therma efficiency and a shortening in the charge-discharge times with the use of the honeycomb core.

Storage tank with spherical capsules filled with PCM coupled to a SWH

- More computation time is required by Enthalpy model than the apparent specific heat model.

\section{PCM filled in}

copper tubes below - Solar air heater's outlet temperature is enhanced the absorber plate of when PCM-TES is used compared to reference.

$$
\text { a the SAH }
$$

PCM sheet placed at

VSF system with

fins at the air way

Simulation and optimization of a ventilated façade can be done with the accurate models developed.

Solar evacuated

- Solar energy collection efficiency fluctuation with PCM for TES 


\begin{tabular}{|c|c|c|c|c|c|c|}
\hline $\begin{array}{l}\text { Experimental } \\
\text { and Numerical }\end{array}$ & $\begin{array}{l}\text { Insulated test } \\
\text { facility }\end{array}$ & Ningxia, China & $\begin{array}{l}\mathrm{CaCl}_{2}-6 \mathrm{H}_{2} \mathrm{O} \\
\text { /expanded } \\
\text { graphite }\end{array}$ & $\begin{array}{l}\text { Heating and } \\
\text { cooling }\end{array}$ & $\begin{array}{l}\text { PCM panels } \\
\text { integrated in the test } \\
\text { room insulated } \\
\text { walls }\end{array}$ & $\begin{array}{l}\text { - Reduction in indoor temperature fluctuations by the } \\
\text { PCM. } \\
\text { - Optimum thickness of PCM was } 8-10 \mathrm{~mm} \text { based } \\
\text { on simulations. }\end{array}$ \\
\hline $\begin{array}{l}\text { Experimental } \\
\text { and Numerical }\end{array}$ & $\begin{array}{l}\text { ANSYS Fluent / } \\
\text { Test cell } \\
\text { containing PCM } \\
\text { mortar }\end{array}$ & $\begin{array}{l}\text { Climatic } \\
\text { Chamber }\end{array}$ & $\begin{array}{l}\text { RT10, MC24, } \\
\text { BSF26, MC28 }\end{array}$ & $\begin{array}{l}\text { Heating and } \\
\text { cooling }\end{array}$ & $\begin{array}{l}\text { PCM embedded in } \\
\text { plastering mortar }\end{array}$ & $\begin{array}{l}\text { - Reduction in heating and cooling demands for } \\
\text { maintaining thermal comfort was achieved with } \\
\text { PCM. }\end{array}$ \\
\hline $\begin{array}{l}\text { Experimental } \\
\text { and Numerical }\end{array}$ & $\begin{array}{l}\text { Cellular passive } \\
\text { solar façade }\end{array}$ & USA & $\begin{array}{l}\text { Paraffin-based } \\
\text { PCM }\end{array}$ & $\begin{array}{l}\text { Heating and } \\
\text { cooling }\end{array}$ & $\begin{array}{c}\text { Small air cells } \\
\text { backed with PCM }\end{array}$ & $\begin{array}{l}\text { - up to } 42 \% \text { reduction in heat gains using PCM. } \\
\text { - Increase in system efficiency for summer and } \\
\text { winter with PCM. }\end{array}$ \\
\hline Experimental & $\begin{array}{l}\text { Radiant floor with } \\
\text { pipes and } \\
\text { supporting net }\end{array}$ & $\begin{array}{l}\text { Climatic } \\
\text { Chamber }\end{array}$ & GR27 & $\begin{array}{l}\text { Heating and } \\
\text { cooling }\end{array}$ & $\begin{array}{l}\text { Granulated PCM } \\
\text { filled in a metal } \\
\text { plate above the } \\
\text { radiant pipes }\end{array}$ & $\begin{array}{l}\text { - saving of } \sim 25 \% \text { of the water used for cooling in } \\
\text { summer. } \\
\text { - No effect on heating in winter. }\end{array}$ \\
\hline Numerical & - & $\begin{array}{l}\text { Casablanca, } \\
\text { Morocco }\end{array}$ & Organic & Heating & $\begin{array}{l}\text { A layer of PCM in } \\
\text { between } 2 \text { layers of } \\
\text { heavy concrete }\end{array}$ & $\begin{array}{l}\text { - Reduction in indoor temperature fluctuations. } \\
\text { - Time shift in temperature oscillations between } \\
\text { PCM wall and reference wall. }\end{array}$ \\
\hline Numerical & $\begin{array}{l}\text { COMSOL } \\
\text { Multiphysics }\end{array}$ & $\begin{array}{l}\text { Rae Bareli and } \\
\text { Bhopal, India }\end{array}$ & $\begin{array}{l}\text { Capric acid, } \\
\text { RT25 and } \\
\text { Paraffin }\end{array}$ & Heating & $\begin{array}{l}\text { Building brick } \\
\text { containing PCM in } \\
\text { cylindrical cavities }\end{array}$ & $\begin{array}{l}-8.31 \% \text { reduction in heat flux through the PCM } \\
\text { brick compared to reference. } \\
\text { - Best PCM was capric acid. }\end{array}$ \\
\hline Numerical & $\begin{array}{l}\text { ANSYS Fluent } \\
18.0\end{array}$ & Tehran, Iran & RT35 & $\begin{array}{l}\text { Heating and } \\
\text { cooling }\end{array}$ & $\begin{array}{l}\text { Building brick } \\
\text { containing PCM in } \\
\text { steel capsules }\end{array}$ & $\begin{array}{l}\text { - Thermal regulation was achieved by PCM bricks } \\
\text { during winter and summer } \\
\text { - Heat storage was sensible in winter and latent in } \\
\text { summer. }\end{array}$ \\
\hline Numerical & EnergyPlus ${ }^{\circledR}$ & Chile & $\begin{array}{c}\text { Knauf } \\
\text { comfortboard } \\
\text { with } \\
\text { Micronal PCM }{ }^{\circledR}\end{array}$ & $\begin{array}{l}\text { Heating and } \\
\text { cooling }\end{array}$ & $\begin{array}{l}\text { PCM plasterboards } \\
\text { placed at the walls } \\
\text { of the building }\end{array}$ & $\begin{array}{l}\text { - Increase in energy performance of the relocatable } \\
\text { building with PCM boards during both summer and } \\
\text { winter. }\end{array}$ \\
\hline Numerical & Fluent & $\begin{array}{l}\text { Ljubljana, } \\
\text { Slovenia }\end{array}$ & RT22HC & $\begin{array}{l}\text { Heating and } \\
\text { cooling }\end{array}$ & $\begin{array}{l}15 \text { or } 30 \text { PCM plates } \\
\text { placed in a stand- } \\
\text { alone office SAH } \\
\text { unit }\end{array}$ & $\begin{array}{l}\text { - Up to } 142 \mathrm{kWh} \text { decreased in energy consumption } \\
\text { can be achieved. }\end{array}$ \\
\hline $\begin{array}{l}\text { Experimental } \\
\text { and Numerical }\end{array}$ & $\begin{array}{l}\text { MATLAB/ } \\
\text { modeled wall }\end{array}$ & China & $\begin{array}{l}\text { Paraffin-based } \\
\quad \text { SSPCM }\end{array}$ & Heating & $\begin{array}{l}\text { Interior northern } \\
\text { wall with PCM } \\
\text { wallboard }\end{array}$ & $\begin{array}{l}\text { - Maximum heating load reduction of } 17 \% \text { during } \\
\text { winter for a PCM thickness of } 30 \mathrm{~mm} \text { and } \mathrm{h}_{\mathrm{L}}=60 \\
\mathrm{~kJ} / \mathrm{kg} \text { and a phase and heating temperatures of } 23 \\
\text { and } 20^{\circ} \mathrm{C} \text { respectively. }\end{array}$ \\
\hline Experimental & $\begin{array}{l}\text { Two identical } \\
\text { rooms }\end{array}$ & Wuhan, China & $\begin{array}{l}\text { Paraffin-based } \\
\text { SSPCM }\end{array}$ & $\begin{array}{l}\text { Heating and } \\
\text { cooling }\end{array}$ & $\begin{array}{l}\text { Double SSPCM } \\
\text { layers on south wall }\end{array}$ & $\begin{array}{l}\text { - Average reduction in indoor temperature of } 0.6^{\circ} \mathrm{C} \\
\text { for summer, and increase of } 0.1{ }^{\circ} \mathrm{C} \text { for winter. }\end{array}$ \\
\hline
\end{tabular}




\begin{tabular}{|c|c|c|c|c|c|c|c|}
\hline Numerical & TRNSYS & Wuhan, China & $\begin{array}{l}\text { Paraffin-based } \\
\quad \text { SSPCM }\end{array}$ & $\begin{array}{l}\text { Heating and } \\
\text { cooling }\end{array}$ & $\begin{array}{l}\text { Double SSPCM } \\
\text { layers on south wall }\end{array}$ & $\begin{array}{l}\text { - Energy consumption reduction of: } \\
20.51 \% \text { (winter) and } 0.65 \% \text { (summer) if PCM layers } \\
\text { are placed on wall's interior and exterior surfaces. } \\
18.75 \% \text { (winter) and } 13.46 \% \text { (summer) if PCM } \\
\text { layers are placed on wall's interior surfaces. }\end{array}$ & {$[170]$} \\
\hline Experimental & $\begin{array}{l}\text { Three identical } \\
\text { huts A,B and C }\end{array}$ & $\begin{array}{c}\text { Chiba } \\
\text { Prefecture, } \\
\text { Japan }\end{array}$ & $\begin{array}{l}\text { Paraffin-based } \\
\text { eutectic SSPCM }\end{array}$ & Heating & $\begin{array}{l}\text { Single layers of } \\
\text { PCM wallboards at } \\
\text { interiors / } 4 \text { SSPCM } \\
\text { wallboards at the } \\
\text { interior floor surface }\end{array}$ & $\begin{array}{l}\text { - Total power consumption reduction of } 18.4 \% \text { and } \\
9.2 \% \text { for hut } \mathrm{C} \text { (single layers on walls, floor and } \\
\text { roof) and hut B ( } 4 \text { layers on floor), respectively. }\end{array}$ & [171] \\
\hline Experimental & $\begin{array}{l}\text { Prototype wall in } \\
\text { thermal chamber }\end{array}$ & $\begin{array}{l}\text { Thermal } \\
\text { chamber }\end{array}$ & $\begin{array}{l}\text { Paraffin-based } \\
\text { SSPCM }\end{array}$ & $\begin{array}{l}\text { Heating and } \\
\text { cooling }\end{array}$ & PCM-bricks wall & $\begin{array}{l}\text { - The PCM-brick is effective only in mid-seasons } \\
\text { with an increase in heat storage capacity of } 12.7 \% \\
\text { compared to reference bricks at a temperature range } \\
\text { of } 15-30^{\circ} \mathrm{C} \text {. }\end{array}$ & [172] \\
\hline Numerical & TRNSYS & $\begin{array}{l}\text { Béchar, } \\
\text { Algeria }\end{array}$ & - & $\begin{array}{l}\text { Heating and } \\
\text { cooling }\end{array}$ & $\begin{array}{l}\text { Double layered } \\
\text { PCM wallboards }\end{array}$ & $\begin{array}{l}\text { - Reduction in annual heating and cooling loads of } \\
12.8 \% \text { and } 1 \% \text {, respectively. }\end{array}$ & [173] \\
\hline Experimental & $\begin{array}{l}\text { Prototype room } \\
\text { with Trombe wall }\end{array}$ & Turkey & GR41 and GR35 & Heating & $\begin{array}{l}\text { South facing } \\
\text { Trombe wall }\end{array}$ & $\begin{array}{l}\text { - Daily solar heat gain by PCM to the heat load of } \\
\text { the prototype varied from } 12 \text { to } 25 \%\end{array}$ & [174] \\
\hline
\end{tabular}


Table 4 Thermo-physical properties of key PCMs used in experimental heating and hybrid applications for buildings

\begin{tabular}{|c|c|c|c|c|c|c|c|c|c|}
\hline PCM ingredients & Type & $\begin{array}{l}\text { Synthetic/ } \\
\text { commercial }\end{array}$ & Application & $\begin{array}{l}\text { Incorporation } \\
\text { Method }\end{array}$ & $\begin{array}{c}\text { Melting } \\
\text { temperature, }{ }^{\circ} \mathrm{C}\end{array}$ & $\begin{array}{l}\text { Latent heat, } \\
\mathrm{kJ} / \mathrm{kg}\end{array}$ & $\begin{array}{c}\text { Thermal } \\
\text { conductivity, } \\
\text { W/m.K } \\
\end{array}$ & $\begin{array}{l}\text { Specific heat, } \\
\mathrm{kJ} / \mathrm{kg} \cdot \mathrm{K}\end{array}$ & Reference \\
\hline Paraffin & Paraffin-based & Synthetic & $\begin{array}{l}\text { Hybrid concrete } \\
\text { wall }\end{array}$ & Immersion & 18 & - & - & - & [144] \\
\hline $\begin{array}{l}40 \% \text { ethylene-based } \\
\text { polymer and } 60 \% \\
\text { paraffin wax }\end{array}$ & $\begin{array}{l}\text { DuPont sheets } \\
\text { Energain }{ }^{\circledR} \\
\text { (Paraffin) }\end{array}$ & Commercial & $\begin{array}{l}\text { Heating walls and } \\
\text { ceiling }\end{array}$ & $\begin{array}{c}\text { Macro- } \\
\text { encapsulation }\end{array}$ & $20-35$ & 72.4 & $\begin{array}{l}0.18 \text { (solid) } \\
0.22 \text { (liquid) }\end{array}$ & - & [89] \\
\hline Paraffin & Paraffin-based & Commercial & $\begin{array}{l}\text { Heating wall, floor } \\
\text { and ceiling }\end{array}$ & $\begin{array}{c}\text { Direct } \\
\text { impregnation }\end{array}$ & $\begin{array}{c}27-29 \text { (for floor) } \\
21.7 \text { (for walls } \\
\text { and ceiling) }\end{array}$ & 120 (for floor) & 0.2 (for both) & $\begin{array}{l}2 \text { (for floor) } \\
2.4 \text { (for walls } \\
\text { and ceiling) }\end{array}$ & [17] \\
\hline $\begin{array}{l}\text { Natural clay }+ \\
\text { graphite }+ \text { cellulose }+ \\
\text { coconut fat }(4 \\
\text { samples, different } \\
\text { percentages })\end{array}$ & Bio-based & Synthetic & Hybrid wallboards & $\begin{array}{c}\text { Shape- } \\
\text { stabilization }\end{array}$ & 23.79 & $\begin{array}{l}59.10 \text { (for } \\
\text { melting) } \\
60.72 \text { (for } \\
\text { freezing) }\end{array}$ & $\begin{array}{l}1.06 \text { (for } \\
\text { composite } \\
\text { PCM) }\end{array}$ & - & [29] \\
\hline Paraffin & $\mathrm{RT} 21 \mathrm{HC}$ & Commercial & $\begin{array}{l}\text { Hybrid solar } \\
\text { façade }\end{array}$ & $\begin{array}{c}\text { Macro- } \\
\text { encapsulated }\end{array}$ & $20-23$ & 190 & 0.2 & 2 & [18] \\
\hline Paraffin & Paraffin-based & Commercial & $\begin{array}{c}\text { Heating floor and } \\
\text { walls }\end{array}$ & $\begin{array}{c}\text { Direct } \\
\text { impregnation }\end{array}$ & $\begin{array}{c}28 \text { (floor) } \\
21.7 \\
\text { (wallboards) }\end{array}$ & $\begin{array}{c}120 \text { (floor) } \\
70 \\
\text { (wallboards) }\end{array}$ & 0.2 (for both) & $\begin{array}{c}2 \text { (floor) } \\
2.4 \\
\text { (wallboards) }\end{array}$ & [123] \\
\hline- & In-organic & Synthetic & Heating floor & $\begin{array}{c}\text { Macro- } \\
\text { encapsulated }\end{array}$ & 29 & 220 & $\begin{array}{l}1.09 \text { (solid) } \\
0.52 \text { (liquid) }\end{array}$ & $\begin{array}{l}1.46 \text { (solid) } \\
1.7 \text { (liquid) }\end{array}$ & [121] \\
\hline $\begin{array}{l}\text { 65:35 solid to liquid } \\
\text { paraffin + high } \\
\text { density polyethylene } \\
+ \text { expanded graphite }\end{array}$ & $\begin{array}{l}\text { Paraffin-based } \\
\text { HCE-SSPCM }\end{array}$ & Synthetic & Heating floor & $\begin{array}{c}\text { Shape- } \\
\text { stabilization }\end{array}$ & 30.3 & 80.85 & 0.66 & 1.92 & [122] \\
\hline Paraffin wax & Paraffin-based & Commercial & $\begin{array}{l}\text { Heating solar air } \\
\text { heater }\end{array}$ & $\begin{array}{c}\text { Macro- } \\
\text { encapsulated }\end{array}$ & 54 & 190 & 0.21 & 2.1 & [128] \\
\hline Salt-hydrate & SP22 & Commercial & $\begin{array}{l}\text { Heating ventilated } \\
\text { façade }\end{array}$ & $\begin{array}{c}\text { Macro- } \\
\text { encapsulated }\end{array}$ & 22 & 170 & 0.6 & 2 & [118] \\
\hline $\begin{array}{l}\mathrm{NaOAc}, 3 \mathrm{H}_{2} \mathrm{O} \\
\text { Salt hydrate }\end{array}$ & In-organic SAT & Synthetic & Heating SDHW & - & 58 & 264 & $0.12-0.67$ & - & [137] \\
\hline Paraffin & RT50 & Commercial & Heating SDHW & $\begin{array}{c}\text { Macro- } \\
\text { encapsulated }\end{array}$ & 51 & 168 & 0.2 & 2 & [138] \\
\hline
\end{tabular}




\begin{tabular}{|c|c|c|c|c|c|c|c|c|c|}
\hline Fatty-acid & Capric acid & Commercial & $\begin{array}{l}\text { Heating } \\
\text { solar water heating } \\
\text { floor }\end{array}$ & $\begin{array}{c}\text { Macro- } \\
\text { encapsulated }\end{array}$ & 29.3 & 162 & $\begin{array}{c}0.36 \text { (solid) } \\
0.17 \text { (liquid) }\end{array}$ & 2 & [127] \\
\hline Salt hydrate & HS58 & Commercial & $\begin{array}{l}\text { Heating solar air } \\
\text { heater }\end{array}$ & $\begin{array}{c}\text { Macro- } \\
\text { encapsulated }\end{array}$ & 58 & 250 & - & 2.5 & {$[60]$} \\
\hline Paraffin & RT22HC & Commercial & $\begin{array}{l}\text { Heating solar air } \\
\text { heater }\end{array}$ & $\begin{array}{c}\text { Macro- } \\
\text { encapsulated }\end{array}$ & 22 & 200 & - & - & [164] \\
\hline Paraffin & GR35 & Commercial & $\begin{array}{c}\text { Heating } \\
\text { Trombe wall }\end{array}$ & $\begin{array}{c}\text { Macro- } \\
\text { encapsulation }\end{array}$ & 35 & - & - & - & [115] \\
\hline Paraffin & GR41 & Commercial & $\begin{array}{l}\text { Heating } \\
\text { Trombe wall }\end{array}$ & $\begin{array}{c}\text { Macro- } \\
\text { encapsulation }\end{array}$ & 41 & - & - & - & [115] \\
\hline - & $\begin{array}{l}\text { Natural TCM } \\
\text { energy saver }\end{array}$ & Commercial & Heating wall & $\begin{array}{c}\text { Macro- } \\
\text { encapsulated }\end{array}$ & $18-26$ & 178.5 & $\begin{array}{c}0.5 \text { (solid) } \\
0.25 \text { (liquid) }\end{array}$ & 1.785 & [165] \\
\hline $\begin{array}{c}\text { Paraffin }+ \\
\text { polypropylene + } \\
\text { elastomer }\end{array}$ & $\begin{array}{l}\text { Paraffin-based } \\
\text { SSPCM }\end{array}$ & Synthetic & $\begin{array}{l}\text { Heating walls, } \\
\text { floor, and ceiling }\end{array}$ & $\begin{array}{c}\text { Shape- } \\
\text { stabilization }\end{array}$ & $19-26$ & 62.24 & 0.12 & - & [113] \\
\hline Mortar + Paraffin & $\begin{array}{l}\text { Micronal PCM® } \\
\text { DS } 5001 \mathrm{X}\end{array}$ & Commercial & $\begin{array}{l}\text { Heating Trombe } \\
\text { wall }\end{array}$ & $\begin{array}{c}\text { Micro- } \\
\text { encapsulated }\end{array}$ & 26 & 120 & 0.55 & $\begin{array}{l}1.1 \text { (solid) } \\
1.07 \text { (liquid) }\end{array}$ & [116] \\
\hline Paraffin & RT25 & Commercial & $\begin{array}{l}\text { Heating Air-PCM } \\
\text { unit }\end{array}$ & $\begin{array}{c}\text { Macro- } \\
\text { encapsulated }\end{array}$ & $23-25$ & $\begin{array}{l}170 \text { (solid) } \\
150 \text { (liquid) }\end{array}$ & 0.2 & 3 & [139] \\
\hline - & - & - & $\begin{array}{l}\text { Heating Solar } \\
\text { façade }\end{array}$ & $\begin{array}{c}\text { Macro- } \\
\text { encapsulation }\end{array}$ & $25-28$ & 184 & 0.2 & $\begin{array}{l}3.11 \text { (solid) } \\
4.81 \text { (liquid) }\end{array}$ & [119] \\
\hline Salt-hydrate & SP22 & Commercial & $\begin{array}{l}\text { Heating Solar } \\
\text { façade }\end{array}$ & $\begin{array}{c}\text { Macro- } \\
\text { encapsulation }\end{array}$ & 22 & 170 & 0.6 & 2 & [132] \\
\hline $\begin{array}{l}\text { Paraffin }+ \text { aluminum } \\
\text { powder }\end{array}$ & Paraffin-based & Synthetic & $\begin{array}{l}\text { Heating solar air } \\
\text { heater }\end{array}$ & $\begin{array}{c}\text { Macro- } \\
\text { encapsulation }\end{array}$ & $52-56$ & 250 & 0.2 & 2.5 & [129] \\
\hline Paraffin & RT54HC & Commercial & $\begin{array}{l}\text { Heating solar air } \\
\text { heater }\end{array}$ & - & $53-54$ & 200 & 0.2 & 2 & [130] \\
\hline $\begin{array}{l}\mathrm{NaOAc}^{\mathrm{NaO}, 3 \mathrm{H}_{2} \mathrm{O}} \\
\text { Salthydrate }\end{array}$ & In-organic SAT & - & $\begin{array}{l}\text { Heating solar } \\
\text { water heater }\end{array}$ & $\begin{array}{c}\text { Macro- } \\
\text { encapsulation }\end{array}$ & $57.31-60.75$ & 173 & 5 & $\begin{array}{l}4.02 \text { (solid) } \\
3.68 \text { (liquid) }\end{array}$ & {$[48]$} \\
\hline Lauric acid & Organic & - & $\begin{array}{l}\text { Heating solar air } \\
\text { heater }\end{array}$ & $\begin{array}{c}\text { Macro- } \\
\text { encapsulated }\end{array}$ & 43 & - & - & - & [131] \\
\hline Paraffin & RT35 & Commercial & $\begin{array}{l}\text { Heating solar } \\
\text { active façade }\end{array}$ & $\begin{array}{c}\text { Macro- } \\
\text { encapsulated }\end{array}$ & 35 & 135 & 0.2 & - & [166] \\
\hline $\begin{array}{c}90 \% \text { Paraffin }+10 \% \\
\text { Aluminum powder }\end{array}$ & Paraffin-based & Synthetic & $\begin{array}{l}\text { Heating underfloor } \\
\text { system }\end{array}$ & $\begin{array}{c}\text { Macro- } \\
\text { encapsulation }\end{array}$ & $35-37$ & 244 & - & - & [175] \\
\hline
\end{tabular}




\begin{tabular}{|c|c|c|c|c|c|c|c|c|c|}
\hline Pure cocoa nut oil & Bio-based & Commercial & $\begin{array}{l}\text { Heating underfloor } \\
\text { system }\end{array}$ & $\begin{array}{c}\text { Macro- } \\
\text { encapsulation }\end{array}$ & 28 & 254 & - & - & {$[176]$} \\
\hline $\begin{array}{c}\text { Stearic acid }+ \\
\text { carbonized sunflower } \\
\text { straw }\end{array}$ & Organic & Synthetic & $\begin{array}{l}\text { Heating Solar } \\
\text { energy storage }\end{array}$ & Impregnation & 66.4 & $\begin{array}{c}186.1 \\
\text { (melting) } \\
186.7 \\
\text { (freezing) }\end{array}$ & 0.33 & - & [177] \\
\hline- & $\begin{array}{c}\text { DuPont } \\
\text { Energain }{ }^{\circledR} \mathrm{M} 27 \\
\text { (bio-based) }\end{array}$ & Commercial & $\begin{array}{l}\text { Hybrid PCM } \\
\text { wallboards }\end{array}$ & $\begin{array}{c}\text { Macro- } \\
\text { encapsulated }\end{array}$ & $21,23,25,27,29$ & 200 & 0.2 & 1.97 & {$[178]$} \\
\hline Cocoa nut oil & Bio-based & Synthetic & $\begin{array}{l}\text { Hybrid PCM } \\
\text { wallboards }\end{array}$ & $\begin{array}{c}\text { Macro- } \\
\text { encapsulated }\end{array}$ & - & 249 & - & $\begin{array}{l}3.2 \text { (solid) } \\
4.1 \text { (liquid) }\end{array}$ & [179] \\
\hline $\begin{array}{c}(78.4 \% \text { Capric acid }+ \\
21.6 \% \text { stearic acid })+ \\
\text { white carbon black } \\
\text { composite }\end{array}$ & Organic eutectic & Synthetic & $\begin{array}{l}\text { Hybrid building } \\
\text { envelops }\end{array}$ & $\begin{array}{l}\text { Shape- } \\
\text { stabilization }\end{array}$ & 20.79 & 78.74 & - & - & {$[180]$} \\
\hline RT27 paraffin + SBS & $\begin{array}{l}\text { Paraffin-based } \\
\text { SSPCM }\end{array}$ & Commercial & $\begin{array}{l}\text { Heating underfloor } \\
\text { system }\end{array}$ & $\begin{array}{c}\text { Shape- } \\
\text { stabilization }\end{array}$ & 27 & 110 & $\begin{array}{l}0.28 \text { (solid) } \\
0.18 \text { (liquid) }\end{array}$ & $\begin{array}{l}2.8 \text { (solid) } \\
2.5 \text { (liquid) }\end{array}$ & [181] \\
\hline $\begin{array}{c}\text { sodium acetate } \\
\text { trihydrate-urea } \\
+ \text { expanded graphite }\end{array}$ & In-organic & Synthetic & $\begin{array}{l}\text { Heating underfloor } \\
\text { system }\end{array}$ & - & 47.84 & 223.1 & 2.076 & - & [182] \\
\hline Paraffin wax & Paraffin-based & - & $\begin{array}{l}\text { Hybrid Solar } \\
\text { water heater }\end{array}$ & $\begin{array}{c}\text { Macro- } \\
\text { encapsulation }\end{array}$ & $48-50$ & 234 & - & $\begin{array}{l}3.2 \text { (solid) } \\
2.8 \text { (liquid) }\end{array}$ & {$[160]$} \\
\hline $\begin{array}{c}\mathrm{CaCl}_{2}-6 \mathrm{H}_{2} \mathrm{O}+ \\
\text { expanded graphite }\end{array}$ & In-organic & Synthetic & Hybrid walls & $\begin{array}{c}\text { Macro- } \\
\text { encapsulation }\end{array}$ & 27.11 & $\begin{array}{c}118.7 \\
\text { (melting) } \\
115.7 \\
\text { (freezing) }\end{array}$ & - & - & [167] \\
\hline Octadecane & Paraffin-based & Commercial & $\begin{array}{l}\text { Hybrid bricks in } \\
\text { buildings }\end{array}$ & $\begin{array}{c}\text { Macro- } \\
\text { encapsulation }\end{array}$ & 27.1 & 249.7 & - & - & {$[183]$} \\
\hline Paraffin wax & RT10 & Commercial & $\begin{array}{l}\text { Hybrid plastering } \\
\text { mortar }\end{array}$ & $\begin{array}{c}\text { Micro- } \\
\text { encapsulation }\end{array}$ & 10 & 150 & - & - & {$[148]$} \\
\hline Paraffin wax & $\mathrm{MC} 24$ & Commercial & $\begin{array}{l}\text { Hybrid plastering } \\
\text { mortar }\end{array}$ & $\begin{array}{c}\text { Micro- } \\
\text { encapsulation }\end{array}$ & 24 & 162.4 & - & - & {$[148]$} \\
\hline Paraffin wax & BSF26 & Commercial & $\begin{array}{l}\text { Hybrid plastering } \\
\text { mortar }\end{array}$ & $\begin{array}{c}\text { Micro- } \\
\text { encapsulation }\end{array}$ & 26 & 110 & - & - & {$[148]$} \\
\hline Paraffin wax & MC28 & Commercial & $\begin{array}{l}\text { Hybrid plastering } \\
\text { mortar }\end{array}$ & $\begin{array}{c}\text { Micro- } \\
\text { encapsulation }\end{array}$ & 28 & 170.1 & - & - & {$[148]$} \\
\hline Paraffin & Paraffin-based & Commercial & $\begin{array}{l}\text { Hybrid ventilated } \\
\text { solar façade }\end{array}$ & - & 22 & 165 & 0.1 & 2.8 & {$[154]$} \\
\hline
\end{tabular}




\begin{tabular}{|c|c|c|c|c|c|c|c|c|c|}
\hline Paraffin & GR27 & Commercial & $\begin{array}{l}\text { Hybrid Radiant } \\
\text { floor }\end{array}$ & $\begin{array}{c}\text { Macro- } \\
\text { encapsulation }\end{array}$ & 27 & 72 & 0.2 & 1.5 & [162] \\
\hline - & Organic & - & Heating wall & - & 16 & 148.5 & 0.145 & $\begin{array}{l}1.46 \text { (solid) } \\
2.13 \text { (liquid) }\end{array}$ & [111] \\
\hline Paraffin & Paraffin-based & - & Heating brick wall & $\begin{array}{c}\text { Macro- } \\
\text { encapsulation }\end{array}$ & 28.2 & 245 & $\begin{array}{c}0.35 \text { (solid) } \\
0.149 \text { (liquid) }\end{array}$ & $\begin{array}{l}1.934 \text { (solid) } \\
2.196 \text { (liquid) }\end{array}$ & [114] \\
\hline Capric acid & Organic & - & Heating brick wall & $\begin{array}{c}\text { Macro- } \\
\text { encapsulation }\end{array}$ & 32 & 152.7 & $\begin{array}{l}0.372 \text { (solid) } \\
0.153 \text { (liquid) }\end{array}$ & $\begin{array}{l}1.9 \text { (solid) } \\
2.4 \text { (liquid) }\end{array}$ & [114] \\
\hline Paraffin & RT25 & Commercial & Heating brick wall & $\begin{array}{c}\text { Macro- } \\
\text { encapsulation }\end{array}$ & 26.6 & 232 & $\begin{array}{l}0.19 \text { (solid) } \\
0.18 \text { (liquid) }\end{array}$ & $\begin{array}{l}1.8 \text { (solid) } \\
2.4 \text { (liquid) }\end{array}$ & [114] \\
\hline Paraffin & $\begin{array}{l}\text { BASF Micronal }{ }^{\circledR} \\
\text { DS 5038X }\end{array}$ & Commercial & Heating & $\begin{array}{l}\text { Micro- } \\
\text { encapsulation }\end{array}$ & 26 & 110 & - & - & [184] \\
\hline Paraffin & MPCM24D & Commercial & Hybrid wall & $\begin{array}{c}\text { Micro- } \\
\text { encapsulation }\end{array}$ & 24 & 160 & - & - & [152] \\
\hline Paraffin & RT35 & Commercial & Hybrid brick wall & $\begin{array}{c}\text { Macro- } \\
\text { encapsulation }\end{array}$ & 35.15 & 160 & 0.2 & 2 & [149] \\
\hline Paraffin & Micronal PCM ${ }^{\circledR}$ & Commercial & Hybrid wallboard & $\begin{array}{c}\text { Micro- } \\
\text { encapsulation }\end{array}$ & 25 & - & 0.23 & 1.625 & [150] \\
\hline HDPE + paraffin & $\begin{array}{l}\text { Paraffin-based } \\
\text { SSPCM }\end{array}$ & Synthesized & Heating wallboard & $\begin{array}{c}\text { Shape- } \\
\text { stabilization }\end{array}$ & 23 & 60 & 0.4 & - & [168] \\
\hline $\begin{array}{c}80 \% \text { paraffin }+15 \% \\
\text { HDPE }+5 \% \text { EG }\end{array}$ & & Synthesized & Hybrid wallboard & $\begin{array}{l}\text { Shape- } \\
\text { stabilization }\end{array}$ & $\begin{array}{c}26.35-36.25 \\
\text { (layer1) } \\
17.03-26.97 \\
\text { (layer 2) }\end{array}$ & $\begin{array}{c}157.6 \text { (layer 1) } \\
148 \text { (layer 2) }\end{array}$ & $\begin{array}{l}0.6 \text { (layer 1) } \\
0.2 \text { (layer 2) }\end{array}$ & 2 (for both) & [169] \\
\hline $\begin{array}{c}80 \% \text { paraffin }+15 \% \\
\text { HDPE }+5 \% \text { EG }\end{array}$ & $\begin{array}{l}\text { Paraffin-based } \\
\text { SSPCM }\end{array}$ & Synthesized & Hybrid wallboard & $\begin{array}{c}\text { Shape- } \\
\text { stabilized }\end{array}$ & - & $\begin{array}{l}190 \text { (layer 1) } \\
225 \text { (layer 2) }\end{array}$ & $\begin{array}{l}0.6 \text { (layer } 1) \\
0.2 \text { (layer 2) }\end{array}$ & 2 (for both) & [170] \\
\hline $\begin{array}{c}\text { hexadecane }+ \\
\text { octadecane }+ \\
\text { polypropylene }+ \\
\text { elastomer }\end{array}$ & $\begin{array}{l}\text { Paraffin-based } \\
\text { eutectic SSPCM }\end{array}$ & Synthesized & $\begin{array}{l}\text { Heating floor / } \\
\text { Heating envelope }\end{array}$ & $\begin{array}{c}\text { Shape- } \\
\text { stabilization }\end{array}$ & $19-26$ & 62.24 & 0.12 & 3.26 & [171] \\
\hline $\begin{array}{l}\text { 70\% Paraffin wax + } \\
\text { HDPE + EG }\end{array}$ & $\begin{array}{l}\text { Paraffin-based } \\
\text { SSPCM }\end{array}$ & Synthesized & Hybrid Brick & $\begin{array}{l}\text { Shape- } \\
\text { stabilization }\end{array}$ & - & - & 0.82 & - & [172] \\
\hline $\begin{array}{c}\text { In-organic salt + EG } \\
+ \text { Silica }\end{array}$ & In-organic & Commercial & $\begin{array}{l}\text { Flat-pipe radiant } \\
\text { heating }\end{array}$ & $\begin{array}{c}\text { Macro- } \\
\text { encapsulation }\end{array}$ & $54-58$ & 225 & $\begin{array}{c}1.1 \text { (solid) } \\
0.55 \text { (liquid) }\end{array}$ & - & [134] \\
\hline $\begin{array}{c}48.5 \mathrm{wt} \% \mathrm{n} \text {-octadecane } \\
+ \text { polystyrene }+5 \mathrm{wt} \% \\
\mathrm{EG}+\text { toluene }\end{array}$ & $\begin{array}{l}\text { Paraffin-based } \\
\text { SSPCM }\end{array}$ & Synthetic & $\begin{array}{c}\text { Solar heating } \\
\text { systems }\end{array}$ & $\begin{array}{c}\text { Shape- } \\
\text { stabilization }\end{array}$ & 27.5 & 98.05 & 1.01 & - & [185] \\
\hline
\end{tabular}




\section{Discussion}

\subsection{Analysis of studied heating applications}

The incorporation of PCM in buildings for occupants' thermal comfort enhancement, during cold winter season, can be in a passive system that depends only on weather conditions and outdoor temperature. PCM passive heating and cooling is easy in installation and does not require additional energy [24]. Mostly, commercial paraffin-based PCM wallboards are used for installation in walls, roofs, ceilings and floors for passive heating. Having remarkable characteristics such as: being non-corrosive to containers -in the case of macro-encapsulation- and of high chemical stability (over 1500 stable cycles), makes it the most used PCM in building passive heating systems [30]. According to the reviewed articles, three important factors must be considered while choosing the proper PCM: (1) PCM amount, (2) PCM position and (3) PCM characteristics: Thermo-physical, chemical, environmental, kinetic and economic characteristics. For instance, placing PCM in the ceiling is more efficient than placing it in the wall [89]. The combination of several passive applications may enhance the thermal comfort and reduce energy consumption. Having all the envelope sides covered with PCM wallboards, i.e. combing roof, walls and floor applications, proved to be more efficient than placing the same amount of PCM in one side only [113]. In addition, mixing or imbibing PCM to construction materials such as bricks sounds quite exciting. PCM bricks is promising in terms of heat storage capabilities but is limited to applications of buildings with frame structure. This is due to their weak performance against flexures and compressions (low bending and flexure strengths) [172]. Another possible method is using the bricks as a second layer over the normal bricks forming both a TES source for thermal regulation and a decorative pattern that can be painted and designed solely, like decorative stones.

The concept of Trombe wall improved to have higher efficiencies than conventional walls with PCMs. There are 7 types of heating based trombe walls. The addition of insulation to building structure enhances the performance of Trombe walls and permits an increase in reduction of energy consumption [186].

Although PCMs used lack high thermal conductivity, their effect on heat load reduction is quite significant that varies around 20-25\% for PCM wallboards in walls. To increase these percentages, nanoparticles can be dispersed to PCM enhancing their conductivities. Other methods are summarized as: the addition of fins, heat pipes, carbon fibers, expanded graphite (EG), and microencapsulation of PCM. For instance, adding A12O3 for paraffin wax in a Trombe wall passive application enhanced the exit air temperature by increasing it $43.24 \%$, on average, compared to Trombe wall with only paraffin wax [187].

One of the most threats that face buildings and has to be considered is its construction material flammability. For instance, a huge fire in Grenfell tower lead to the death of 72 victims were the external Aluminum-polyethylene cladding that are the main cause of the fire spread [188]. Regarding PCMs, organic paraffin is an example of flammable PCM that contributes to the propagation of fire. The addition of retardants into the used PCM can enhance its flammability properties as in the case studied by Palacios-Trujillo et al. [189]. It was proven that the addition of flame retardants such as ammonium polyphosphate, hydro-magnesite and magnesium hydroxide to fatty acid mixture PCM improved its flammability properties, however no effect was observed for paraffin RT21. A study by Cai et al. showed that the addition of organophilic montmorillonite (OMT) nanocomposites to a form-stable paraffin contributes to flammability properties enhancement [190]. Accordingly, PCM used in buildings has to follow the fire safety guidelines, and be developed and enhanced as in many research studies $[191,192]$ so that no restrictions ban its utility.

Filling glazed windows with PCM is another interesting approach, however, their overall heat reduction effect is relatively small if compared to other passive heating applications. Instead of filling glass windows, it is more preferred to adapt PCM to window shutters for the sake of sustaining sun light entering to the room.

PCM also can be incorporated actively, by installing PCM layers to a mechanically driven heating or hybrid system. It is shown through the studied literature that active systems are of higher efficiency than passive systems. Special focus is given to active underfloor radiant heating systems coupled with PCM. Mostly, the design of the 
floor ensures that the PCM layer is placed above the heating system. Yet, it is important to study the placement of the PCM layers under the radiant heating system. For radiant hydronic pipes, it is also important to investigate the thermal performance of PCM when the pipes pass through the PCM and vary the position to optimize the configuration. Energy consumption reduction varies around 30\% for the reviewed literature which is higher than that of single passive applications.

For both heating methods: active and passive, it is essential to prepare proper comparisons between reference and designed novel application. This comparison, whether the study is experimentally or numerically done, is completed by varying the overall thickness of the studied part of the building upon adding PCM. At this point, it might be drawn out that the results may infer that PCM is functioning as an insulation, rather than being a heat storage source. A reference of inserting insulation materials to the reference building versus PCM is of valuable importance.

Another scarcity found in the literature, is the lack of experimental test for a year-round or near year-round duration. It is understood that numerical approaches are developed to decrease the cost of experiments, however, the big difference between a tool full of assumptions and a real test for a real prototype under real test conditions is clear.

An additional important scarcity, is the comparative studies between selective Numerical tools, such as comparing the results of ANSYS Fluent with COMSOL Multiphysics, or comparing TRNSYS with EnergyPlus. It is important to discuss the capabilities of each numerical tool to direct researchers toward using the right tool within the right application with the aim of obtaining most accurate results.

\subsection{Analysis of studied hybrid applications}

Obtaining NZEB is the goal. The operation of passive and active systems in both heating and cooling forms a hybrid system that is the first attempt toward the goal. The main factors affecting the right choice of PCM for a specified application during a specified time and zone are summarized by Suayfane [24] as: (1) Weather condition, (2) PCM phase change range, type and characteristics, (3) Encapsulation technique, (4) PCM thickness and effective volume, (5) Application (location and installation), (6) Category type (passive or active), (7) Building orientation and characteristics and (8) Real life conditions. The simplest hybrid system is obtained by the adaptation of double PCM wallboard layers in building envelopes which reduces energy consumption during winter and summer seasons [169]. Research studies proved that the effect of integrating PCM in building envelopes, as passive strategies, has fluctuating impacts on energy consumption reduction $[169,170]$. Thus, hybrid systems require optimization toward providing constant feedback during all varying weather conditions.

The use of PCM in doors is absent, although it is present in windows. More studies on the effect of integrating PCM in doors are needed to investigate their effects on thermal comfort enhancement. Also the adaptation of PCM in furniture is still lacking.

Most results in studied literature on hybrid applications focused on combining two layers of PCM wallboards having different melting range. Active and passive systems were studied and compared separately [193], however attempts on evaluating the performance of combining active with passive applications, which is promising in terms of building energy efficiency enhancement, is still lacking. Some attempts by different researchers were made and showed high effectiveness. For instance, Zhao et al. [194] combined the three different applications of solar façade, PV cooling, and radiative cooling utilizing PCM layers for the sake of building cooling. The hybrid system was more efficient with high energy performance compared to the traditional one. Kong et al. [195] performed an experimental study coupling the performance of passive PCM wallboards integrated in walls and ceiling, with an active solar heater system utilizing capillary tubes at the east and north walls. Results were promising showing a reduction of $44.16 \%$ in daily heating energy consumption in the PCM room compared to the reference room with no PCM. Zhao et al. [196] prepared and studied a solar heating system equipped with a PCM storage tank for heating conditions. The study includes seven operation modes and simulation models. The 
combination of the plate solar collector, PCM storage tank, plate heat exchanger and auxiliary heat source has ensured the coverage of the entire heating season for the first time. Another study by Abed et al. [197] included investigation of the performance enhancement by $\mathrm{Al}_{2} \mathrm{O}_{3} /$ water Nano-fluid when used as the heat exchanger working fluid in a hybrid cooling system. The system coupled the utility of PV panels and that of a Trombe wall. Results showed an increase in the thermal and electrical efficiencies of the solar cell, however a hostile effect on the indoor space temperature.

Combining different heating systems can take three forms: Passive-Passive, Active-Active and Active-Passive systems. Possible combinations of different applications are presented in Table 5. As shown in the table there are 105 possible combinations for heating systems that might be designed and optimized each in a specific study to form hybrid system of high efficiency toward NZEB. The combination of more applications can give more possibilities which show how much the field of PCM in buildings is wide and challenging. 
Table 5 Possible combinations of active and passive heating applications of PCM proposed by this study.

\begin{tabular}{|c|c|c|c|c|c|c|c|c|c|c|c|c|c|c|c|c|}
\hline \multirow{2}{*}{\multicolumn{2}{|c|}{$\begin{array}{l}\text { Possible combined } \\
\text { applications for heating } \\
\text { applications }\end{array}$}} & \multirow{3}{*}{$\begin{array}{l}\text { Category } \\
\text { Application }\end{array}$} & \multicolumn{7}{|c|}{ Passive } & \multicolumn{7}{|c|}{ Active } \\
\hline & & & Building & Plastering & Insulation & Floor & Roof/Ceiling & Trombe & Solar & Underfloor & $\begin{array}{l}\text { Solar } \\
\text { air }\end{array}$ & $\begin{array}{l}\text { Solar } \\
\text { water }\end{array}$ & $\begin{array}{l}\text { Solar } \\
\text { heat }\end{array}$ & HVAC & SDHW & Ventilated \\
\hline Category & Application & & P1 & P2 & P3 & P4 & P5 & P6 & P7 & A1 & A2 & A3 & A4 & A5 & A6 & A7 \\
\hline \multirow{7}{*}{ Passive } & $\begin{array}{l}\text { Building } \\
\text { walls }\end{array}$ & P1 & P1P1 & P1P2 & P1P3 & P1P4 & P1P5 & P1P6 & P1P7 & P1A1 & P1A2 & P1A3 & P1A4 & P1A5 & P1A6 & P1A7 \\
\hline & $\begin{array}{c}\text { Plastering } \\
\text { mortar }\end{array}$ & P2 & & P2P2 & $\mathrm{P} 2 \mathrm{P} 3$ & P2P4 & P2P5 & P2P6 & $\mathrm{P} 2 \mathrm{P} 7$ & P2A1 & $\mathrm{P} 2 \mathrm{~A} 2$ & P2A3 & P2A4 & P2A5 & P2A6 & P2A7 \\
\hline & $\begin{array}{c}\text { Insulation } \\
\text { materials }\end{array}$ & P3 & & & P3P3 & P3P4 & P3P5 & P3P6 & P3P7 & P3A1 & P3A2 & PЗАЗ & P3A4 & P3A5 & P3A6 & P3A7 \\
\hline & Floor & P4 & & & & P4P4 & P4P5 & P4P6 & P4P7 & P4A1 & P4A2 & P4A3 & P4A4 & P4A5 & P4A6 & P4A7 \\
\hline & Roof/Ceiling & P5 & & & & & P5P5 & P5P6 & P5P7 & P5A1 & P5A2 & P5A3 & P5A4 & P5A5 & P5A6 & P5A7 \\
\hline & $\begin{array}{c}\begin{array}{c}\text { Trombe } \\
\text { wall }\end{array} \\
\end{array}$ & P6 & & & & & & P6P6 & P6P7 & P6A1 & P6A2 & P6A3 & P6A4 & P6A5 & P6A6 & P6A7 \\
\hline & Solar façade & P7 & & & & & & & P7P7 & P7A1 & P7A2 & P7A3 & P7A4 & P7A5 & P7A6 & P7A7 \\
\hline \multirow{7}{*}{ Active } & $\begin{array}{c}\text { Underfloor } \\
\text { Radiant }\end{array}$ & A1 & & & & & & & & A1A1 & $\mathrm{A} 1 \mathrm{~A} 2$ & A1A3 & A1A4 & A1A5 & A1A6 & A1A7 \\
\hline & $\begin{array}{c}\begin{array}{c}\text { Solar air } \\
\text { heater }\end{array} \\
\end{array}$ & A2 & & & & & & & & & $\mathrm{A} 2 \mathrm{~A} 2$ & A2A3 & A2A4 & A2A5 & A2A6 & A2A7 \\
\hline & $\begin{array}{c}\text { Solar water } \\
\text { heater }\end{array}$ & A3 & & & & & & & & & & A3A3 & A3A4 & A3A5 & A3A6 & A3A7 \\
\hline & $\begin{array}{c}\text { Solar heat } \\
\text { pump }\end{array}$ & A4 & & & & & & & & & & & A4A4 & A4A5 & A4A6 & A4A7 \\
\hline & $\begin{array}{c}\text { HVAC } \\
\text { system }\end{array}$ & A5 & & & & & & & & & & & & A5A5 & A5A6 & A5A7 \\
\hline & SDHW & A6 & & & & & & & & & & & & & A6A6 & A6A7 \\
\hline & $\begin{array}{l}\text { Ventilated } \\
\text { façade }\end{array}$ & A7 & & & & & & & & & & & & & & A7A7 \\
\hline
\end{tabular}




\section{Conclusions and Recommendations}

A review on recent research literature in regarding to the usage of phase change materials as latent heat thermal energy storage strategies applied to residential and commercial buildings is presented in this article. Firstly, Phase change materials and their concepts, classification, selection criteria and properties tests were discussed. Then two application aspects were presented: Heating applications and Hybrid (heating and cooling covering annual needs) applications in buildings. Presented literature were classified into two categories in each studied aspect: Passive and active systems and a helical diagram that summarizes these applications was illustrated. In terms of summary, two tables were generated, the first summing up most heating and hybrid literature presenting the type of study, used PCM, climate and most valuable outcomes, and the second showing a summary of the used PCMs in each classified application with their respective thermo-physical properties and encapsulation techniques.

From thermal performance analysis presented in each study that have been reviewed and by analyzing the outcomes presented in table 3 , it is concluded that:

- PCM do serve as thermal buffers that prevails load shifting and consequently reduces indoor temperature swings resulting in residential thermal comfort in heating applications while it needed more research effort regarding hybrid applications.

- Most hybrid applications were based on verifying a numerical model with an experimental outcome of a small-scale prototype and then annual studies were conducted with a plenty of assumptions. This assures that the need of more real scale experimental investigation is highly required for adequate results.

- Optimization of PCM melting temperature and other thermos-physical properties in the domain of studying most suitable PCMs according to climates requires more attention. Studies on PCM size, mass and location are still few, and most present optimization studies are based on pure numerical models that are not covered by experimental evidence.

- Economic analysis must be added to thermal performance and energy efficiency analysis to have wider view of PCM capabilities.

- Most important, the majority of the reviewed articles focused on studying one application using PCM, and few covered combined applications such as the use of PCM wallboards in walls and ceiling as a passive heating method, in combination with underfloor electrical heating with incorporated PCM as active heating method. The amount of choices for combining two or more applications in one test facility is high and require organized work distribution on research groups all over the world.

- The right choice of PCM, with the optimization of its variable parameters, and the suitable combination of more than one application is capable of improving thermal behavior of buildings to reach net zero energy building state for retrofits and new buildings.

Table 4 showing different PCMs used allows the generation of the following conclusions

- Most PCMs that are already commercialized are Paraffin-based. A plenty of PCMs such as bio-based, inorganic, and eutectic mixtures need commercialization.

- Incorporation techniques in literature were at most macro-encapsulation within containers, packages and capsules...etc. Despite the decent benefits of such incorporation technique, special focus must rely on other incorporation techniques, mainly micro-encapsulation and nano-PCM utilization.

- In addition to the type of application and design issues, the range of human thermal comfort differs with the climate change; this have led to the variation in melting temperature of each selected PCM in each study.

- The performance of combined PCMs in one application is an important aim to focus on in upcoming studies. 105 possibilities for systems that varies between: Active-Active, Passive-Passive, and ActivePassive for heating applications are to be studied to obtain an optimized design for a NZEB by PCM.

Finally, it is worth mentioning that PCMs is a promising evolving technology that can help in energy consumption reduction toward sustainable living. This limitless horizon of unknown potentials in such domain requires more research that is organized and direct properly. 


\section{References}

[1] M. He, L. Yang, W. Lin, J. Chen, X. Mao, Z. Ma, Preparation, thermal characterization and examination of phase change materials (PCMs) enhanced by carbon-based nanoparticles for solar thermal energy storage, Journal of Energy Storage. 25 (2019). https://doi.org/10.1016/j.est.2019.100874.

[2] Y. Zhang, J. Zhang, X. Li, X. Wu, Preparation of hydrophobic lauric acid / SiO 2 shape-stabilized phase change materials for thermal energy storage, Journal of Energy Storage. 21 (2019) 611-617. https://doi.org/10.1016/j.est.2018.12.022.

[3] N. Aslfattahi, R. Saidur, A. Arifutzzaman, R. Sadri, N. Bimbo, M.F.M. Sabri, P.A. Maughan, L. Bouscarrat, R.J. Dawson, S.M. Said, B.T. Goh, N.A.C. Sidik, C. Sidik, Experimental investigation of energy storage properties and thermal conductivity of a novel organic phase change material/MXene as A new class of nanocomposites, Journal of Energy Storage. 27 (2020). https://doi.org/10.1016/j.est.2019.101115.

[4] S.G. Ranjbar, G. Roudini, F. Barahuie, Fabrication and characterization of phase change material-SiO2 nanocomposite for thermal energy storage in buildings, Journal of Energy Storage. 27 (2020). https://doi.org/10.1016/j.est.2019.101168.

[5] W. Yang, R. Xu, B. Yang, J. Yang, Experimental and numerical investigations on the thermal performance of a borehole ground heat exchanger with PCM backfil, Energy. (2019). https://doi.org/10.1016/j.energy.2019.02.172.

[6] X. Bao, Y. Tian, L. Yuan, H. Cui, W. Tang, W.H. Fung, Development of high performance PCM cement composites for passive solar buildings, Energy and Buildings. 194 (2019) 33-45. https://doi.org/10.1016/j.enbuild.2019.04.011.

[7] S. Jeong, S. Wi, S. Jin, J. Lee, S. Kim, An experimental study on applying organic PCMs to gypsumcement board for improving thermal performance of buildings in different climates, Energy and Buildings. 190 (2019) 183-194. https://doi.org/10.1016/j.enbuild.2019.02.037.

[8] Y. Song, C. Li, H. Yu, Y. Tang, Z. Xia, Optimization of the phase-change wallboard test method: Experimental and numerical investigation, Journal of Energy Storage. 30 (2020). https://doi.org/10.1016/j.est.2020.101559.

[9] A.O. Acheampong, Economic growth, CO2emissions and energy consumption: What causes what and where?, Energy Economics. 74 (2018) 677-692. https://doi.org/10.1016/j.eneco.2018.07.022.

[10] K. Sohag, R.A. Begum, S.M. Syed Abdullah, M. Jaafar, Dynamics of energy use, technological innovation, economic growth and trade openness in Malaysia, Energy. 90 (2015) 1497-1507. https://doi.org/10.1016/j.energy.2015.06.101.

[11] V. Andreoni, S. Galmarini, Drivers in CO2emissions variation: A decomposition analysis for 33 world countries, Energy. 103 (2016) 27-37. https://doi.org/10.1016/j.energy.2016.02.096.

[12] K. Ahmed, M. Bhattacharya, Z. Shaikh, M. Ramzan, I. Ozturk, Emission intensive growth and trade in the era of the Association of Southeast Asian Nations (ASEAN) integration: An empirical investigation from ASEAN-8, Journal of Cleaner Production. 154 (2017) 530-540. https://doi.org/10.1016/j.jclepro.2017.04.008.

[13] D. Zhou, C.Y. Zhao, Y. Tian, Review on thermal energy storage with phase change materials (PCMs) in building applications, Applied Energy. 92 (2012) 593-605. https://doi.org/10.1016/j.apenergy.2011.08.025.

[14] International Energy Agency, IEA Roadmap targets 2015 2035, (n.d.). https://www.iea.org/publications/freepublications/publication/IEA_Solar_HC_Roadmap_Foldout_Print. pdf.

[15] M. Rabani, M. Rabani, Heating performance enhancement of a new design trombe wall using rectangular thermal fin arrays: An experimental approach, Journal of Energy Storage. 24 (2019). https://doi.org/10.1016/j.est.2019.100796.

[16] N. Putra, S. Rawi, M. Amin, E. Kusrini, E.A. Kosasih, T. Mahlia, Preparation of beeswax/multi-walled carbon nanotubes as novel shape-stable nanocomposite phase change material for thermal energy storage, Journal of Energy Storage. 21 (2019) 32-39. https://doi.org/10.1016/j.est.2018.11.007.

[17] P. Devaux, M.M. Farid, Benefits of PCM underfloor heating with PCM wallboards for space heating in winter, Applied Energy. 191 (2017) 593-602. https://doi.org/10.1016/j.apenergy.2017.01.060.

[18] R. Vanaga, A. Blumberga, R. Freimanis, T. Mols, D. Blumberga, Solar facade module for nearly zero energy building, Energy. 157 (2018) 1025-1034. https://doi.org/10.1016/j.energy.2018.04.167. 
[19] M.R. Poole, S.B. Shah, M.D. Boyette, L.F. Stikeleather, T. Cleveland, Performance of a coupled transpired solar collector - phase change material-based thermal energy storage system, Energy and Buildings. 161 (2018) 72-79. https://doi.org/10.1016/j.enbuild.2017.12.027.

[20] X. Sun, M.A. Medina, K.O. Lee, X. Jin, Laboratory assessment of residential building walls containing pipe-encapsulated phase change materials for thermal management, Energy. 163 (2018) 383-391. https://doi.org/10.1016/j.energy.2018.08.159.

[21] F.F.D.A. Landi, C. Fabiani, A.L. Pisello, Palm oil for seasonal thermal energy storage applications in buildings: The potential of multiple melting ranges in blends of bio-based fatty acids, Journal of Energy Storage. 29 (2020). https://doi.org/10.1016/j.est.2020.101431.

[22] C. Piselli, V. Lucia, A. Laura, How to enhance thermal energy storage effect of PCM in roofs with varying solar reflectance: Experimental and numerical assessment of a new roof system for passive cooling in different climate conditions, Solar Energy. (2018) 0-1. https://doi.org/10.1016/j.solener.2018.06.047.

[23] J.H. Patel, M.N. Qureshi, P.H. Darji, Experimental analysis of thermal energy storage by phase change material system for cooling and heating applications, Materials Today: Proceedings. 5 (2018) 14901500. https://doi.org/10.1016/j.matpr.2017.11.238.

[24] F. Souayfane, F. Fardoun, P.H. Biwole, Phase change materials (PCM) for cooling applications in buildings: A review, Energy and Buildings. 129 (2016) 396-431. https://doi.org/10.1016/j.enbuild.2016.04.006.

[25] C. Li, H. Yu, Y. Song, Experimental investigation of thermal performance of microencapsulate d PCMcontaine d wallboard by two measurement modes, Energy and Buildings. 184 (2019) 34-43. https://doi.org/10.1016/j.enbuild.2018.11.032.

[26] 20-20-20 Goals, (n.d.). https://esmig.eu/page/20-20-20-goals.

[27] European 20-20-20 Targets, (n.d.). https://www.recs.org/glossary/european-20-20-20-targets.

[28] Y. Khattari, T. El Rhafiki, N. Choab, T. Kousksou, M. Alaphilippe, Y. Zeraouli, Apparent heat capacity method to investigate heat transfer in a composite phase change material, 28 (2020). https://doi.org/10.1016/j.est.2020.101239.

[29] L. Boussaba, A. Foufa, S. Makhlouf, G. Lefebvre, L. Royon, Elaboration and properties of a composite bio-based PCM for an application in building envelopes, Construction and Building Materials. 185 (2018) 156-165. https://doi.org/10.1016/j.conbuildmat.2018.07.098.

[30] K. Du, J. Calautit, Z. Wang, Y. Wu, H. Liu, A review of the applications of phase change materials in cooling, heating and power generation in different temperature ranges, Applied Energy. 220 (2018) 242 273. https://doi.org/10.1016/j.apenergy.2018.03.005.

[31] M.R. Kadivar, M.A. Moghimi, P. Sapin, C.N. Markides, Annulus eccentricity optimisation of a phasechange material (PCM) horizontal double-pipe thermal energy store, Journal of Energy Storage. 26 (2019). https://doi.org/10.1016/j.est.2019.101030.

[32] L.N. N, Assessment of latent heat thermal storage systems operating with multiple phase change materials, Journal of Energy Storage. 23 (2019) 442-455. https://doi.org/10.1016/j.est.2019.04.008.

[33] K. Faraj, M. Khaled, J. Faraj, F. Hachem, C. Castelain, Phase change material thermal energy storage systems for cooling applications in buildings: A review, Renewable and Sustainable Energy Reviews. (2019). https://doi.org/10.1016/j.rser.2019.109579.

[34] G. Gholamibozanjani, M. Farid, Application of an Active PCM Storage System into a Building for Heating/Cooling Load Reduction, Energy. (2020). https://doi.org/10.1016/j.energy.2020.118572.

[35] G. Ferrer, S. Gschwander, A. Solé, C. Barreneche, A.I. Fernández, P. Schossig, L.F. Cabeza, Empirical equation to estimate viscosity of paraffin, Journal of Energy Storage. 11 (2017) 154-161. https://doi.org/10.1016/j.est.2017.03.002.

[36] P.W. Griffiths, P.C. Eames, Performance of chilled ceiling panels using phase change material slurries as the heat transport medium, APPLIED THERMAL ENGINEERING. 27 (2007) 1756-1760. https://doi.org/10.1016/j.applthermaleng.2006.07.009.

[37] A.Y. Uzan, Y. Kozak, Y. Korin, I. Harary, H. Mehling, G. Ziskind, A novel multi-dimensional model for solidification process with supercooling, International Journal of Heat and Mass Transfer. 106 (2017) 91-102. https://doi.org/10.1016/j.ijheatmasstransfer.2016.10.046.

[38] P.C. Eames, P.W. Griffiths, Thermal behaviour of integrated solar collector/storage unit with $65^{\circ} \mathrm{C}$ phase change material, Energy Conversion and Management. 47 (2006) 3611-3618. https://doi.org/10.1016/j.enconman.2006.02.029. 
[39] L. Vorbeck, S. Gschwander, P. Thiel, B. Lüdemann, P. Schossig, Pilot application of phase change slurry in a $5 \mathrm{~m} 3$ storage, Applied Energy. 109 (2013) 538-543.

https://doi.org/10.1016/j.apenergy.2012.11.019.

[40] P.W. Griffiths, M.J. Huang, M. Smyth, Improving the heat retention of integrated collector/storage solar water heaters using Phase Change Materials, International Journal of Ambient Energy. 28 (2007) 89-98. https://doi.org/10.1080/01430750.2007.9675029.

[41] S. Koohi-Fayegh, M.A. Rosen, A review of energy storage types, applications and recent developments, Journal of Energy Storage. 27 (2020). https://doi.org/10.1016/j.est.2019.101047.

[42] J. Heier, C. Bales, V. Martin, Combining thermal energy storage with buildings - A review, Renewable and Sustainable Energy Reviews. 42 (2015) 1305-1325. https://doi.org/10.1016/j.rser.2014.11.031.

[43] S. Da Cunha, J.L. De Aguiar, Phase change materials and energy efficiency of buildings: A review of knowledge, Journal of Energy Storage. 27 (2020). https://doi.org/10.1016/j.est.2019.101083.

[44] A. Kasaeian, L. bahrami, F. Pourfayaz, E. Khodabandeh, W.M. Yan, Experimental studies on the applications of PCMs and nano-PCMs in buildings: A critical review, Energy and Buildings. 154 (2017) 96-112. https://doi.org/10.1016/j.enbuild.2017.08.037.

[45] M.M. Kenisarin, K. Mahkamov, S.C. Costa, I. Makhkamova, Melting and solidification of PCMs inside a spherical capsule: A critical review, Journal of Energy Storage. 27 (2020). https://doi.org/10.1016/j.est.2019.101082.

[46] M.E. Zayed, J. Zhao, W. Li, A.H. Elsheikh, A. Mohamed, L. Jing, A.E. Geweda, Recent progress in phase change materials storage containers: Geometries, design considerations and heat transfer improvement methods, Journal of Energy Storage. 30 (2020). https://doi.org/10.1016/j.est.2020.101341.

[47] V.M. Swami, A.T. Autee, A. T.R., Experimental analysis of solar fish dryer using phase change material, Journal of Energy Storage. 20 (2018) 310-315. https://doi.org/10.1016/j.est.2018.09.016.

[48] T. Bouhal, T.E. Rhafiki, T. Kousksou, A. Jamil, Y. Zeraouli, PCM addition inside solar water heaters : Numerical comparative approach, Journal of Energy Storage. 19 (2018) 232-246. https://doi.org/10.1016/j.est.2018.08.005.

[49] M. Ali, R.F. Viegas, M.B.S. Kumar, R.K. Kannapiran, M. Feroskhan, Enhancement of heat transfer in para ffi $\mathrm{n}$ wax PCM using nano graphene composite for industrial helmets, Journal of Energy Storage. 26 (2019). https://doi.org/10.1016/j.est.2019.100982.

[50] X. Huang, G. Alva, Y. Jia, G. Fang, Morphological characterization and applications of phase change materials in thermal energy storage : A review, Renewable and Sustainable Energy Reviews. 72 (2017) 128-145. https://doi.org/10.1016/j.rser.2017.01.048.

[51] S.S. Chandel, T. Agarwal, Review of current state of research on energy storage, toxicity, health hazards and commercialization of phase changing materials, Renewable and Sustainable Energy Reviews. 67 (2017) 581-596. https://doi.org/10.1016/j.rser.2016.09.070.

[52] Y. Xie, M.S. Gilmour, Y. Yuan, H. Jin, H. Wu, A review on house design with energy saving system in the UK, 71 (2017) 29-52. https://doi.org/10.1016/j.rser.2017.01.004.

[53] H. Johra, P. Heiselberg, Influence of internal thermal mass on the indoor thermal dynamics and integration of phase change materials in furniture for building energy storage: A review, Renewable and Sustainable Energy Reviews. 69 (2017) 19-32. https://doi.org/10.1016/j.rser.2016.11.145.

[54] J. Giro-paloma, M. Martínez, L.F. Cabeza, A.I. Fernández, Types , methods , techniques , and applications for microencapsulated phase change materials ( MPCM ): A review, Renewable and Sustainable Energy Reviews. 53 (2016) 1059-1075. https://doi.org/10.1016/j.rser.2015.09.040.

[55] V.V. Tyagi, D. Buddhi, PCM thermal storage in buildings: A state of art, Renewable and Sustainable Energy Reviews. 11 (2007) 1146-1166. https://doi.org/10.1016/j.rser.2005.10.002.

[56] Y. Lin, Y. Jia, G. Alva, G. Fang, Review on thermal conductivity enhancement, thermal properties and applications of phase change materials in thermal energy storage, Renewable and Sustainable Energy Reviews. 82 (2018) 2730-2742. https://doi.org/10.1016/j.rser.2017.10.002.

[57] M. Iten, S. Liu, A. Shukla, A review on the air-PCM-TES application for free cooling and heating in the buildings, Renewable and Sustainable Energy Reviews. 61 (2016) 175-186. https://doi.org/10.1016/j.rser.2016.03.007.

[58] A.K. Pandey, M.S. Hossain, V. V Tyagi, N. Abd, J.A.L. Selvaraj, A. Sari, Novel approaches and recent developments on potential applications of phase change materials in solar energy, Renewable and Sustainable Energy Reviews. 82 (2018) 281-323. https://doi.org/10.1016/j.rser.2017.09.043.

[59] A. De Gracia, L. Navarro, J. Coma, S. Serrano, J. Romaní, G. Pérez, L.F. Cabeza, Experimental set-up 
for testing active and passive systems for energy savings in buildings - Lessons learnt, Renewable and Sustainable Energy Reviews. 82 (2018) 1014-1026. https://doi.org/10.1016/j.rser.2017.09.109.

[60] S. Esakkimuthu, A. Hakim, C. Palaniappan, M. Spinnler, J. Blumenberg, R. Velraj, Experimental investigation on phase change material based thermal storage system for solar air heating applications, Solar Energy. 88 (2013) 144-153. https://doi.org/10.1016/j.solener.2012.11.006.

[61] C. Zeng, S. Liu, A. Shukla, Adaptability research on phase change materials based technologies in, Renewable and Sustainable Energy Reviews. 73 (2017) 145-158. https://doi.org/10.1016/j.rser.2017.01.117.

[62] Y. Lin, G. Alva, G. Fang, Review on thermal performances and applications of thermal energy storage systems with inorganic phase change materials, Energy. (2018). https://doi.org/10.1016/j.energy.2018.09.128.

[63] L. Navarro, A. De Gracia, S. Colclough, M. Browne, S.J. Mccormack, P. Grif, L.F. Cabeza, Thermal energy storage in building integrated thermal systems: A review. Part 1. active storage systems, Renewable Energy. 88 (2016) 526-547. https://doi.org/10.1016/j.renene.2015.11.040.

[64] L. Navarro, A. De Gracia, D. Niall, A. Castell, M. Browne, S.J. Mccormack, P. Grif, L.F. Cabeza, Thermal energy storage in building integrated thermal systems: A review. Part 2. Integration as passive system, Renewable Energy. 85 (2016) 1334-1356. https://doi.org/10.1016/j.renene.2015.06.064.

[65] G. Alva, Y. Lin, G. Fang, An overview of thermal energy storage systems, Energy. 144 (2018) 341-378. https://doi.org/10.1016/j.energy.2017.12.037.

[66] S. Guo, Q. Liu, J. Sun, H. Jin, A review on the utilization of hybrid renewable energy, Renewable and Sustainable Energy Reviews. 91 (2018) 1121-1147. https://doi.org/10.1016/j.rser.2018.04.105.

[67] M. Alizadeh, S.M. Sadrameli, Development of free cooling based ventilation technology for buildings: Thermal energy storage (TES) unit, performance enhancement techniques and design considerations - A review, Renewable and Sustainable Energy Reviews. 58 (2016) 619-645. https://doi.org/10.1016/j.rser.2015.12.168.

[68] H. Goudarzi, A. Mostafaeipour, Energy saving evaluation of passive systems for residential buildings in hot and dry regions, Renewable and Sustainable Energy Reviews. 68 (2017) 432-446. https://doi.org/10.1016/j.rser.2016.10.002.

[69] H. Omrany, A. Ghaffarianhoseini, A. Ghaffarianhoseini, K. Raahemifar, J. Tookey, Application of passive wall systems for improving the energy effciency in buildings : A comprehensive review, Renewable and Sustainable Energy Reviews. 62 (2016) 1252-1269. https://doi.org/10.1016/j.rser.2016.04.010.

[70] K. Panchabikesan, K. Vellaisamy, V. Ramalingam, Passive cooling potential in buildings under various climatic conditions in India, Renewable and Sustainable Energy Reviews. 78 (2017) 1236-1252. https://doi.org/10.1016/j.rser.2017.05.030.

[71] A. Safari, R. Saidur, F.A. Sulaiman, Y. Xu, J. Dong, A review on supercooling of Phase Change Materials in thermal energy storage systems, Renewable and Sustainable Energy Reviews. (2016) 1-15. https://doi.org/10.1016/j.rser.2016.11.272.

[72] R. Zeinelabdein, S. Omer, G. Gan, Critical review of latent heat storage systems for free cooling in buildings, Renewable and Sustainable Energy Reviews. 82 (2018) 2843-2868. https://doi.org/10.1016/j.rser.2017.10.046.

[73] S. Mengjie, N. Fuxin, M. Ning, H. Yanxin, D. Shiming, Review on building energy performance improvement using phase change materials, Energy and Buildings. 158 (2018) 776-793. https://doi.org/10.1016/j.enbuild.2017.10.066.

[74] N. Morovat, A.K. Athienitis, J.A. Candanedo, V. Dermardiros, Simulation and performance analysis of an active PCM-heat exchanger intended for building operation optimization, Energy and Buildings. 199 (2019) 47-61. https://doi.org/10.1016/j.enbuild.2019.06.022.

[75] A. Sharma, V. V. Tyagi, C.R. Chen, D. Buddhi, Review on thermal energy storage with phase change materials and applications, Renewable and Sustainable Energy Reviews. 13 (2009) 318-345. https://doi.org/10.1016/j.rser.2007.10.005.

[76] K.S. Reddy, V. Mudgal, T.K. Mallick, Review of latent heat thermal energy storage for improved material stability and effective load management, Journal of Energy Storage. 15 (2018) 205-227. https://doi.org/10.1016/j.est.2017.11.005.

[77] D.J. Morrison, S.I. Abdel-Khalik, Effects of phase-change energy storage on the performance of airbased and liquid-based solar heating systems, Solar Energy. 20 (1978) 57-67. 
https://doi.org/10.1016/0038-092X(78)90141-X.

[78] V. De Matteis, A. Cannavale, F. Martellotta, R. Rinaldi, P. Calcagnile, F. Ferrari, U. Ayr, F. Fiorito, Nano-encapsulation of phase change materials: From design to thermal performance, simulations and toxicological assessment, Energy and Buildings. 188-189 (2019) 1-11. https://doi.org/10.1016/j.enbuild.2019.02.004.

[79] M.J. Muthoka, Z. Xuelai, X. Xioafeng, Experimental investigation on supercooling, thermal conductivity and stability of nano fluid based composite phase change material, Journal of Energy Storage. 17 (2018) 47-55. https://doi.org/10.1016/j.est.2018.02.006.

[80] A.A. Ghoneim, Comparison of Theoretical Models of Phase Change and Sensible Heat Storage for Air and Water-Based Solar Heating Systems, Solar Energy. 42 (1989) 209-220.

[81] S.M. Wang, P. Matiašovský, P. Mihálka, C.M. Lai, Experimental investigation of the daily thermal performance of a mPCM honeycomb wallboard, Energy and Buildings. 159 (2018) 419-425. https://doi.org/10.1016/j.enbuild.2017.10.080.

[82] S. Motahar, Experimental study and ANN-based prediction of melting heat transfer in a uniform heat flux PCM enclosure, Journal of Energy Storage. 30 (2020). https://doi.org/10.1016/j.est.2020.101535.

[83] Q. Wang, R. Wu, Y. Wu, C.Y. Zhao, Parametric analysis of using PCM walls for heating loads reduction, Energy and Buildings. 172 (2018) 328-336. https://doi.org/10.1016/j.enbuild.2018.05.012.

[84] H.G. Barkmann, F.C. Wessling, Use of buildings structural components for thermal storage, in: Proceedings of the Workshop on Solar Energy Storage Subsystems for the Heating and Cooling of Buildings, 1975.

[85] M. Telkes, Remarks on "Thermal energy storage using sodium sulfate decahydrate and water," Solar Energy. 20 (1978) 1978.

[86] G.A. Lane, T. Dow, C. Co, Technical note, 27 (1981) 73-75.

[87] A. Elgafy, K. Lafdi, Effect of carbon nanofiber additives on thermal behavior of phase change materials, 43 (2005) 3067-3074. https://doi.org/10.1016/j.carbon.2005.06.042.

[88] K.P. Venkitaraj, S. Suresh, B. Praveen, S.C. Nair, Experimental heat transfer analysis of macro packed neopentylglycol with $\mathrm{CuO}$ nano additives for building cooling applications, Journal of Energy Storage. 17 (2018) 1-10. https://doi.org/10.1016/j.est.2018.02.005.

[89] A. Mourid, M. El Alami, F. Kuznik, Experimental investigation on thermal behavior and reduction of energy consumption in a real scale building by using phase change materials on its envelope, Sustainable Cities and Society. 41 (2018) 35-43. https://doi.org/10.1016/j.scs.2018.04.031.

[90] S.E. Kalnæs, B.P. Jelle, Phase change materials and products for building applications: A state-of-the-art review and future research opportunities, Elsevier B.V., 2015. https://doi.org/10.1016/j.enbuild.2015.02.023.

[91] B.P. Jelle, S.E. Kalnæs, Phase Change Materials for Application in Energy-Efficient Buildings, Elsevier Ltd, 2017. https://doi.org/10.1016/B978-0-08-101128-7.00003-4.

[92] X. Fang, L. Fan, Q. Ding, X. Yao, Y. Wu, J. Hou, X. Wang, Z. Yu, G. Cheng, Y. Hu, Thermal energy storage performance of paraffin-based composite phase change materials filled with hexagonal boron nitride nanosheets, Energy Conversion and Management. 80 (2014) 103-109.

https://doi.org/10.1016/j.enconman.2014.01.016.

[93] H. Yang, Y. Wang, Q. Yu, G. Cao, X. Sun, R. Yang, Q. Zhang, F. Liu, X. Di, J. Li, C. Wang, G. Li, Low-cost, three-dimension, high thermal conductivity, carbonized wood-based composite phase change materials for thermal energy storage, Energy. (2018). https://doi.org/10.1016/j.energy.2018.06.207.

[94] R. Baetens, B. Petter, A. Gustavsen, Phase change materials for building applications : A state-of-the-art review, 42 (2012) 1361-1368. https://doi.org/10.1016/j.enbuild.2010.03.026.

[95] A.N. Keshteli, M. Sheikholeslami, Nanoparticle-enhanced Phase change materials have engrossed augmenting consideration to, Journal of Molecular Liquids. (2018) \#pagerange\#. https://doi.org/10.1016/j.molliq.2018.10.151.

[96] Y.E. Milián, A. Gutiérrez, M. Grágeda, S. Ushak, A review on encapsulation techniques for inorganic phase change materials and the in fl uence on their thermophysical properties, Renewable and Sustainable Energy Reviews. 73 (2017) 983-999. https://doi.org/10.1016/j.rser.2017.01.159.

[97] H. Akeiber, P. Nejat, M. Zaimi, A. Majid, M.A. Wahid, F. Jomehzadeh, I. Zeynali, J. Kaiser, B. Richard, S. Ahmad, A review on phase change material ( PCM ) for sustainable passive cooling in building envelopes, Renewable and Sustainable Energy Reviews. 60 (2016) 1470-1497. https://doi.org/10.1016/j.rser.2016.03.036. 
[98] R.M. Saeed, J.P. Schlegel, C. Castano, R. Sawafta, V. Kuturu, Preparation and thermal performance of methyl palmitate and lauric acid eutectic mixture as phase change material ( PCM ), Journal of Energy Storage. 13 (2017) 418-424. https://doi.org/10.1016/j.est.2017.08.005.

[99] D.G. Atinafu, W. Dong, X. Huang, H. Gao, G. Wang, Introduction of organic-organic eutectic PCM in mesoporous N-doped carbons for enhanced thermal conductivity and energy storage capacity, Applied Energy. 211 (2018) 1203-1215. https://doi.org/10.1016/j.apenergy.2017.12.025.

[100] S.A. Memon, H.Z. Cui, H. Zhang, F. Xing, Utilization of macro encapsulated phase change materials for the development of thermal energy storage and structural lightweight aggregate concrete, Applied Energy. 139 (2015) 43-55. https://doi.org/10.1016/j.apenergy.2014.11.022.

[101] A. Solé, L. Miró, C. Barreneche, I. Martorell, L.F. Cabeza, Review of the T -history method to determine thermophysical properties of phase change materials ( PCM ), Renewable and Sustainable Energy Reviews. 26 (2013) 425-436. https://doi.org/10.1016/j.rser.2013.05.066.

[102] Y. Cui, J. Xie, J. Liu, S. Pan, Review of Phase Change Materials Integrated in Building Walls for Energy Saving, Procedia Engineering. 121 (2015) 763-770. https://doi.org/10.1016/j.proeng.2015.09.027.

[103] K. Yang, N. Zhu, C. Chang, D. Wang, S. Yang, S. Ma, A methodological concept for phase change material selection based on multi-criteria decision making ( MCDM ): A case study, Energy. 165 (2018) 1085-1096. https://doi.org/10.1016/j.energy.2018.10.022.

[104] X. Sun, K.O. Lee, M.A. Medina, Y. Chu, Melting temperature and enthalpy variations of phase change materials ( PCMs ): a differential scanning calorimetry ( DSC ) analysis, 1594 (2018). https://doi.org/10.1080/01411594.2018.1469019.

[105] H. Günther, W.F. Hemminger, H. Flammersheim, Differential Scanning Calorimetry, Springer, 2013.

[106] Z. Yinping, Y. Jiang, A simple method, the-history method, of determining the heat of fusion, specific heat and thermal conductivity of phase change materials, Measurement Science and Technology. 3 (1999) 201.

[107] Fourier Transform Infrared Spectroscopy, Nano and Microscale Drug Delivery Systems. (2017).

[108] G. Sang, Y. Cao, M. Fan, G. Lu, Development of a novel sulphoalumitate cement-based composite combing fine steel fibers and phase change materials for thermal energy storage, Energy and Buildings. (2018). https://doi.org/10.1016/j.enbuild.2018.10.039.

[109] A. Sar1, R.K. Sharma, G. Hekimo, Preparation, characterization, thermal energy storage properties and temperature control performance of form-stabilized sepiolite based composite phase change materials, Energy and Buildings. 189 (2019) 111-119. https://doi.org/10.1016/j.enbuild.2019.02.008.

[110] A. Hassan, A.I. Mourad, Y. Rashid, N. Ismail, Thermal and structural performance of geopolymer concrete containing phase change material encapsulated in expanded clay, Energy and Buildings. 191 (2019) 72-81. https://doi.org/10.1016/j.enbuild.2019.03.005.

[111] M. Faraji, P. Ain, J. Fournier, B. Lacarrière, O. Le, Numerical study of the thermal behavior of a novel Assessing the Composite feasibility PCM / concrete of using the heat wall temperature function for a long-term district heat demand forecast, Energy Procedia. 139 (2017) 105-110. https://doi.org/10.1016/j.egypro.2017.11.181.

[112] L. Karim, F. Barbeon, P. Gegout, A. Bontemps, L. Royon, New phase-change material components for thermal management of the light weight envelope of buildings, Energy and Buildings. 68 (2014) 703706. https://doi.org/10.1016/j.enbuild.2013.08.056.

[113] H.B. Kim, M. Mae, Y. Choi, Application of shape-stabilized phase-change material sheets as thermal energy storage to reduce heating load in Japanese climate, Building and Environment. (2017). https://doi.org/10.1016/j.buildenv.2017.08.038.

[114] K. Kant, A. Shukla, A. Sharma, Heat transfer studies of building brick containing phase change materials, Solar Energy. 155 (2017) 1233-1242. https://doi.org/10.1016/j.solener.2017.07.072.

[115] Y. Kara, A. Kurnuc, Performance of coupled novel triple glass and phase change material wall in the heating season: An experimental study, Solar Energy. 86 (2012) 2432-2442. https://doi.org/10.1016/j.solener.2012.05.012.

[116] E. Leang, P. Tittelein, L. Zalewski, S. Lassue, Numerical study of a composite Trombe solar wall integrating microencapsulated PCM, Energy Procedia. 122 (2017) 1009-1014. https://doi.org/10.1016/j.egypro.2017.07.467.

[117] Z. Hu, W. He, J. Ji, S. Zhang, A review on the application of Trombe wall system in buildings, Renewable and Sustainable Energy Reviews. (2016) 0-1. https://doi.org/10.1016/j.rser.2016.12.003.

[118] A. de Gracia, L. Navarro, A. Castell, Á. Ruiz-Pardo, S. Alvárez, L.F. Cabeza, Experimental study of a 
ventilated facade with PCM during winter period, Energy and Buildings. 58 (2013) 324-332. https://doi.org/10.1016/j.enbuild.2012.10.026.

[119] C. Liu, G. Zhang, M. Ar, J. Bian, D. Li, Thermal performance of non-ventilated multilayer glazing facades fi lled with phase change material, 177 (2019) 464-470. https://doi.org/10.1016/j.solener.2018.11.044.

[120] R.J.D. Wong, M. Al-jethelah, S. Ebadi, A. Singh, S. Mahmud, Investigation of phase change materials integrated with fin-tube baseboard convector for space heating, Energy and Buildings. 187 (2019) 241256. https://doi.org/10.1016/j.enbuild.2019.02.005.

[121] G. Zhou, J. He, Thermal performance of a radiant floor heating system with different heat storage materials and heating pipes, Applied Energy. 138 (2015) 648-660. https://doi.org/10.1016/j.apenergy.2014.10.058.

[122] W. Cheng, B. Xie, R. Zhang, Z. Xu, Y. Xia, Effect of thermal conductivities of shape stabilized PCM on under-floor heating system, APPLIED ENERGY. 144 (2015) 10-18. https://doi.org/10.1016/j.apenergy.2015.01.055.

[123] R. Barzin, J.J.J. Chen, B.R. Young, M.M. Farid, Application of PCM underfloor heating in combination with PCM wallboards for space heating using price based control system, Applied Energy. 148 (2015) 39-48. https://doi.org/10.1016/j.apenergy.2015.03.027.

[124] K. Lin, Y. Zhang, X. Xu, H. Di, R. Yang, P. Qin, Modeling and simulation of under- oor electric heating system with shape-stabilized PCM plates, 39 (2004) 1427-1434. https://doi.org/10.1016/j.buildenv.2004.04.005.

[125] K. Lin, Y. Zhang, X. Xu, H. Di, Experimental study of under-floor electric heating system with shapestabilized PCM plates, Energy and Buildings. 37 (2005) 215-220. https://doi.org/10.1016/j.enbuild.2004.06.017.

[126] Z. Yinping, G. Zhou, R. Yang, K. Lin, Our research on shape-stabilized PCM in energy-efficient buildings, Proceeding of Ecostock, 10th. (2006) 1-9.

[127] K. Huang, G. Feng, J. Zhang, Experimental and numerical study on phase change material floor in solar water heating system with a new design, Solar Energy. 105 (2014) 126-138. https://doi.org/10.1016/j.solener.2014.03.009.

[128] A.E. Kabeel, A. Khalil, S.M. Shalaby, M.E. Zayed, Experimental investigation of thermal performance of flat and v-corrugated plate solar air heaters with and without PCM as ther[1] Kabeel AE, Khalil A, Shalaby SM, Zayed ME. Experimental investigation of thermal performance of flat and v-corrugated plate, Energy Conversion and Management. 113 (2016) 264-272. https://doi.org/10.1016/j.enconman.2016.01.068.

[129] R. Moradi, A. Kianifar, S. Wongwises, Optimization of a solar air heater with phase change materials : Experimental and numerical study, Experimental Thermal and Fluid Science. (2017). https://doi.org/10.1016/j.expthermflusci.2017.07.011.

[130] M. Abuşka, S. Şevik, A. Kayapunar, A comparative investigation of the effect of honeycomb core on the latent heat storage with PCM in solar air heater, Applied Thermal Engineering. (2018). https://doi.org/10.1016/j.applthermaleng.2018.11.056.

[131] A. Wadhawan, A.S. Dhoble, V.B. Gawande, Analysis of the effects of use of thermal energy storage device ( TESD ) in solar air heater, Alexandria Engineering Journal. (2017). https://doi.org/10.1016/j.aej.2017.03.016.

[132] A. De Gracia, L. Navarro, A. Castell, Á. Ruiz-pardo, Solar absorption in a ventilated facade with PCM . Experimental results, 30 (2012) 986-994. https://doi.org/10.1016/j.egypro.2012.11.111.

[133] A. De Gracia, L. Navarro, A. Castell, L.F. Cabeza, Numerical study on the thermal performance of a ventilated facade with PCM, Applied Thermal Engineering. 61 (2013) 372-380. https://doi.org/10.1016/j.applthermaleng.2013.07.035.

[134] H. Sun, B. Lin, Z. Lin, Y. Zhu, Experimental study on a novel fl at-heat-pipe heating system integrated with phase change material and thermoelectric unit, Energy. 189 (2019) 116181. https://doi.org/10.1016/j.energy.2019.116181.

[135] W. Youssef, Y. Ge, S.A. Tassou, Indirect expansion solar assisted heat pump system for hot water production with latent heat storage and applicable control strategy, Energy Procedia. 123 (2017) 180187. https://doi.org/10.1016/j.egypro.2017.07.258.

[136] M.T. Plytaria, C. Tzivanidis, E. Bellos, K.A. Antonopoulos, Energetic investigation of solar assisted heat pump under fl oor heating systems with and without phase change materials, Energy Conversion and 
Management. 173 (2018) 626-639. https://doi.org/10.1016/j.enconman.2018.08.010.

[137] J. Deng, S. Furbo, W. Kong, J. Fan, Thermal performance assessment and improvement of a solar domestic hot water tank with PCM in the mantle, Energy and Buildings. 172 (2018) 10-21. https://doi.org/10.1016/j.enbuild.2018.04.058.

[138] M. Gorzin, M.J. Hosseini, A.A. Ranjbar, R. Bahrampoury, Investigation of PCM charging for the energy saving of domestic hot water system, Applied Thermal Engineering. 137 (2018) 659-668. https://doi.org/10.1016/j.applthermaleng.2018.04.016.

[139] M. Iten, S. Liu, A. Shukla, Experimental validation of an air-PCM storage unit comparing the Effective Heat Capacity and Enthalpy methods through CFD simulations, Energy. (2018). https://doi.org/10.1016/j.energy.2018.04.128.

[140] M. Fadl, P.C. Eames, An experimental investigation of the heat transfer and energy storage characteristics of a compact latent heat thermal energy storage system for domestic hot water applications, Energy. 188 (2019) 116083. https://doi.org/10.1016/j.energy.2019.116083.

[141] X. Sun, J. Jovanovic, Y. Zhang, S. Fan, Y. Chu, Y. Mo, S. Liao, Use of encapsulated phase change materials in lightweight building walls for annual thermal regulation, Energy. 180 (2019) 858-872. https://doi.org/10.1016/j.energy.2019.05.112.

[142] K. Saafi, N. Daouas, Energy and cost efficiency of phase change materials integrated in building envelopes under Tunisia Mediterranean climate, Energy. (2019) 115987. https://doi.org/10.1016/j.energy.2019.115987.

[143] U. Berardi, S. Soudian, Experimental investigation of latent heat thermal energy storage using PCMs with different melting temperatures for building retrofit, Energy and Buildings. 185 (2019) 180-195. https://doi.org/10.1016/j.enbuild.2018.12.016.

[144] A. Laura Pisello, C. Fabiani, F. Cotana, New experimental technique to investigate the thermal behavior of PCM/doped concrete for enhancing thermal/energy storage capability of building envelope, Energy Procedia. 126 (2017) 139-146. https://doi.org/10.1016/j.egypro.2017.08.133.

[145] L. Derradji, F.B. Errebai, M. Amara, Effect of PCM in Improving the Thermal Comfort in Buildings, Energy Procedia. 107 (2017) 157-161. https://doi.org/10.1016/j.egypro.2016.12.159.

[146] F. Souayfane, P. Henry, F. Fardoun, P. Achard, Energy performance and economic analysis of a TIMPCM wall under different climates, Energy. 169 (2019) 1274-1291. https://doi.org/10.1016/j.energy.2018.12.116.

[147] N. Hanchi, H. Hamza, J. Lahjomri, A. Oubarra, Thermal behavior in dynamic regime of a multilayer roof provided with two phase change materials in the case of a local conditioned, Energy Procedia. 139 (2017) 92-97. https://doi.org/10.1016/j.egypro.2017.11.179.

[148] M. Kheradmand, M. Azenha, J.L.B. Aguiar, J. Castro-Gomes, Experimental and numerical studies of hybrid PCM embedded in plastering mortar for enhanced thermal behaviour of buildings, 94 (2016) 250-261. https://doi.org/10.1016/j.energy.2015.10.131.

[149] S. Dabiri, M. Mehrpooya, E.G. Nezhad, Latent and sensible heat analysis of PCM incorporated in a brick for cold and hot climatic conditions, utilizing computational fluid dynamics, Energy. (2018). https://doi.org/10.1016/j.energy.2018.06.074.

[150] P. Marin, M. Saffari, A. De Gracia, X. Zhu, M.M. Farid, L.F. Cabeza, S. Ushak, Energy savings due to the use of PCM for relocatable lightweight buildings passive heating and cooling in different weather conditions, Energy \& Buildings. 129 (2016) 274-283. https://doi.org/10.1016/j.enbuild.2016.08.007.

[151] S. Grynning, F. Goia, B. Time, Dynamic thermal performance of a PCM window system : characterization using large scale measurements, Energy Procedia. 78 (2015) 85-90. https://doi.org/10.1016/j.egypro.2015.11.119.

[152] B.A. Young, G. Falzone, Z. Wei, G. Sant, L. Pilon, Reduced-scale experiments to evaluate performance of composite building envelopes containing phase change materials, Construction and Building Materials. 162 (2018) 584-595. https://doi.org/10.1016/j.conbuildmat.2017.11.160.

[153] D. Li, Y. Wu, C. Liu, G. Zhang, M. Arıc1, Energy investigation of glazed windows containing NanoPCM in different seasons, Energy Conversion and Management. 172 (2018) 119-128. https://doi.org/10.1016/j.enconman.2018.07.015.

[154] G. Guldentops, S. Van Dessel, A numerical and experimental study of a cellular passive solar faï ¿1/2ade system for building thermal control, Solar Energy. 149 (2017) 102-113. https://doi.org/10.1016/j.solener.2017.03.078.

[155] N. Sarier, E. Onder, Organic phase change materials and their textile applications: An overview, 
Thermochimica Acta. 540 (2012) 7-60. https://doi.org/10.1016/j.tca.2012.04.013.

[156] U. Stritih, P. Charvat, R. Koželj, L. Klimes, E. Osterman, M. Ostry, V. Butala, PCM Thermal Energy Storage in Solar Heating of Ventilation Air-Experimental and Numerical Investigations, Sustainable Cities and Society. (2017). https://doi.org/10.1016/j.scs.2017.10.018.

[157] E. Osterman, V. Butala, U. Stritih, PCM thermal storage system for 'free' heating and cooling of buildings, Energy \& Buildings. (2015). https://doi.org/10.1016/j.enbuild.2015.04.012.

[158] A. Maccarini, G. Hultmark, N.C. Bergsøe, A. Afshari, Free cooling potential of a PCM-based heat exchanger coupled with a novel HVAC system for simultaneous heating and cooling of buildings, Sustainable Cities and Society. 42 (2018) 384-395. https://doi.org/10.1016/j.scs.2018.06.016.

[159] M.A. Said, H. Hassan, A study on the thermal energy storage of different phase change materials incorporated with the condenser of air-conditioning unit and their effect on the unit performance, Energy and Buildings. 202 (2019) 109353. https://doi.org/10.1016/j.enbuild.2019.109353.

[160] W. Wu, S. Dai, Z. Liu, Y. Dou, J. Hua, M. Li, X. Wang, X. Wang, Experimental study on the performance of a novel solar water heating system with and without PCM, Solar Energy. 171 (2018) 604-612. https://doi.org/10.1016/j.solener.2018.07.005.

[161] M. Behi, S.A. Mirmohammadi, M. Ghanbarpour, M. Behi, S.A. Mirmohammadi, H. Behi, B. Palm, Evaluation of a novel solar driven sorption cooling/heating system integrated with PCM Storage compartment, Energy. (2018). https://doi.org/10.1016/j.energy.2018.08.166.

[162] R. Ansuini, R. Larghetti, A. Giretti, M. Lemma, Radiant floors integrated with PCM for indoor temperature control, Energy and Buildings. 43 (2011) 3019-3026. https://doi.org/10.1016/j.enbuild.2011.07.018.

[163] A. Laaouatni, N. Martaj, R. Bennacer, M. Lachi, M. El, M. El, Thermal building control using active ventilated block integrating phase change material, Energy and Buildings. 187 (2019) 50-63. https://doi.org/10.1016/j.enbuild.2019.01.024.

[164] U. Stritih, V. V Tyagi, R. Stropnik, H. Paksoy, F. Haghighat, M.M. Joybari, Integration of passive PCM technologies for net-zero energy buildings, Sustainable Cities and Society. 41 (2018) 286-295. https://doi.org/10.1016/j.scs.2018.04.036.

[165] Y. Li, J. Zhou, E. Long, X. Meng, Experimental study on thermal performance improvement of building envelopes by integrating with phase change material in an intermittently heated room, Sustainable Cities and Society. (2018). https://doi.org/10.1016/j.scs.2018.01.040.

[166] G. Diarce, Á. Campos-celador, K. Martin, A. Urresti, A. García-romero, J.M. Sala, A comparative study of the CFD modeling of a ventilated active façade including phase change materials, APPLIED ENERGY. 126 (2014) 307-317. https://doi.org/10.1016/j.apenergy.2014.03.080.

[167] R. Ye, W. Lin, K. Yuan, X. Fang, Z. Zhang, Experimental and numerical investigations on the thermal performance of building plane containing $\mathrm{CaCl}<\inf >2</ \mathrm{inf}>\cdot 6 \mathrm{H}<\mathrm{inf}>2</ \mathrm{inf}>\mathrm{O} /$ expanded graphite composite phase change material, Applied Energy. 193 (2017) 325-335. https://doi.org/10.1016/j.apenergy.2017.02.049.

[168] C. Chen, H. Guo, Y. Liu, H. Yue, C. Wang, A new kind of phase change material ( PCM ) for energystoring wallboard, 40 (2008) 882-890. https://doi.org/10.1016/j.enbuild.2007.07.002.

[169] N. Zhu, N. Hu, P. Hu, F. Lei, S. Li, Experiment study on thermal performance of building integrated with double layers shape-stabilized phase change material wallboard, Energy. (2018). https://doi.org/10.1016/j.energy.2018.11.042.

[170] N. Zhu, M. Wu, P. Hu, L. Xu, F. Lei, S. Li, Performance study on different location of double layers SSPCM wallboard in office building, Energy \& Buildings. 158 (2018) 23-31. https://doi.org/10.1016/j.enbuild.2017.09.075.

[171] J. Kosny, E. Kossecka, A. Brzezinski, A. Tleoubaev, D. Yarbrough, Dynamic thermal performance analysis of fiber insulations containing bio-based phase change materials ( PCMs ), Energy \& Buildings. 52 (2012) 122-131. https://doi.org/10.1016/j.enbuild.2012.05.021.

[172] X. Wang, H. Yu, L. Li, M. Zhao, Experimental assessment on a kind of composite wall incorporated with shape-stabilized phase change materials ( SSPCMs ), 128 (2016) 567-574. https://doi.org/10.1016/j.enbuild.2016.07.031.

[173] B.M. Diaconu, M. Cruceru, Novel concept of composite phase change material wall system for yearround thermal energy savings, Energy \& Buildings. 42 (2010) 1759-1772. https://doi.org/10.1016/j.enbuild.2010.05.012.

[174] Y.A. Kara, Diurnal performance analysis of phase change material walls, APPLIED THERMAL 
ENGINEERING. 102 (2016) 1-8. https://doi.org/10.1016/j.applthermaleng.2016.03.141.

[175] E. Mays, E. Mays, Using phase change material in under floor heating Available ScienceDirect ScienceDirect ScienceDirect Using phase change material in under floor heating Akroush forecast, Energy Procedia. 119 (2017) 806-811. https://doi.org/10.1016/j.egypro.2017.07.101.

[176] K. Faraj, O. Farhat, A. Hamdan, F. Hachem, M. Khaled, J. Faraj, C. Castelain, Experimental Study of Underfloor Electrical Heating System with Integrated Experimental Study of Underfloor Electrical Heating System with Integrated CO-PCM Plates, 6th European Conference on Renewable Energy Systems: Proceedings, Istanbul, Turkey. (2018).

[177] R. Wen, W. Zhang, Z. Lv, Z. Huang, W. Gao, A novel composite Phase change material of Stearic Acid / Carbonized sunflower straw for thermal energy storage, Materials Letters. 215 (2018) 42-45. https://doi.org/10.1016/j.matlet.2017.12.008.

[178] S. Memarian, B. Mohammad, R. Fayaz, S. Asadi, Single and combined phase change materials: Their effect on seasonal transition period, Energy \& Buildings. 169 (2018) 453-472. https://doi.org/10.1016/j.enbuild.2018.03.085.

[179] W.A. Putri, Z. Fahmi, I.M. Sutjahja, D. Kurnia, S. Wonorahardjo, Thermophysical parameters of coconut oil and its potential application as the thermal energy storage system in Indonesia, Journal of Physics: Conference Series. 739 (2016). https://doi.org/10.1088/1742-6596/739/1/012065.

[180] A.F. Liu, J. Zhu, J. Liu, B. Ma, Preparation and properties of capric-stearic acid / White Carbon Black composite for thermal storage in building envelope, Energy \& Buildings. (2017). https://doi.org/10.1016/j.enbuild.2017.09.076.

[181] L. Royon, L. Karim, A. Bontemps, Thermal energy storage and release of a new component with PCM for integration in floors for thermal management of buildings, Energy and Buildings. 63 (2013) 29-35. https://doi.org/10.1016/j.enbuild.2013.03.042.

[182] W. Fu, T. Zou, X. Liang, S. Wang, X. Gao, Z. Zhang, Y. Fang, Thermal properties and thermal conductivity enhancement of composite phase change material using sodium acetate trihydrateurea/expanded graphite for radiant floor heating system, Applied Thermal Engineering. 138 (2018) 618626. https://doi.org/10.1016/j.applthermaleng.2018.04.102.

[183] H. Cui, W. Tang, Q. Qin, F. Xing, W. Liao, H. Wen, Development of structural-functional integrated energy storage concrete with innovative macro-encapsulated PCM by hollow steel ball, Applied Energy. 185 (2017) 107-118. https://doi.org/10.1016/j.apenergy.2016.10.072.

[184] L. Olivieri, J.A. Tenorio, D. Revuelta, L. Navarro, L.F. Cabeza, Developing a PCM-enhanced mortar for thermally active precast walls, Construction and Building Materials. 181 (2018) 638-649. https://doi.org/10.1016/j.conbuildmat.2018.06.013.

[185] Z. Zhang, G. Alva, M. Gu, G. Fang, Experimental investigation on n-octadecane/polystyrene/expanded graphite composites as form-stable thermal energy storage materials, Energy. (2018). https://doi.org/10.1016/j.energy.2018.06.006.

[186] F. Abbassi, N. Dimassi, L. Dehmani, Energetic study of a Trombe wall system under different Tunisian building configuration, Energy \& Buildings. (2014). https://doi.org/10.1016/j.enbuild.2014.05.036.

[187] M.T. Chaichan, A.H. Al-hamdani, A.M. Kasem, Enhancing a Trombe wall charging and discharging processes by adding nano-A12O3 to phase change materials, International Journal of Scientific \& Engineering Research. (2016).

[188] B. BBC Visual Journalism team, Grenfell Tower: What happened, (2017). https://www.bbc.com/news/uk-40301289.

[189] A. Palacios Trujillo, L. Haurie Ibarra, A.I. Fernández, L.F. Cabeza, C. Barreneche, Flammability properties of organic phase change material, in: 13th International Conference on Energy Storage: Greenstock, 2015: pp. 1-14.

[190] Y. Cai, L. Song, Q. He, D. Yang, Y. Hu, Preparation, thermal and flammability properties of a novel form-stable phase change materials based on high density polyethylene/ poly (ethylene-co-vinyl acetate)/organophilic montmorillonite nanocomposites/paraffin compounds, Energy Conversion and Management. 49 (2008) 2055-2062. https://doi.org/10.1016/j.enconman.2008.02.013.

[191] S. Gnanachelvam, A. Ariyanayagam, M. Mahendran, Fire resistance of LSF wall systems lined with different wallboards including bio-PCM mat, Journal of Building Engineering. (2020). https://doi.org/10.1016/j.jobe.2020.101628.

[192] M.S. Mclaggan, R.M. Hadden, M. Gillie, Flammability assessment of Phase Change Material wall lining and insulation materials with different weight fractions, Energy \& Buildings. (2017). 
https://doi.org/10.1016/j.enbuild.2017.08.012.

[193] G. Gholamibozanjani, M. Farid, A comparison between passive and active PCM systems applied to buildings, Renewable Energy. (2020). https://doi.org/10.1016/j.renene.2020.08.007.

[194] Y. Zhou, S. Zheng, G. Zhang, Study on the energy performance enhancement of a new PCMs integrated hybrid system with the active cooling and hybrid ventilations, Energy. 179 (2019) 111-128. https://doi.org/10.1016/j.energy.2019.04.173.

[195] X. Kong, L. Wang, H. Li, G. Yuan, C. Yao, Experimental study on a novel hybrid system of active composite PCM wall and solar thermal system for clean heating supply in winter, Solar Energy. 195 (2020) 259-270. https://doi.org/10.1016/j.solener.2019.11.081.

[196] J. Zhao, Y. Ji, Y. Yuan, Z. Zhang, J. Lu, Seven Operation Modes and Simulation Models of Solar Heating System with PCM Storage Tank, Energies. 10 (2017). https://doi.org/10.3390/en10122128.

[197] A.A. Abed, O.K. Ahmed, M.M. Weis, K.I. Hamada, Performance augmentation of a PV/Trombe wall using A12O3/Water nano-fluid: An experimental investigation, Renewable Energy. 157 (2020) 515-529. https://doi.org/10.1016/j.renene.2020.05.052. 